\title{
Analysis of Paleofluids in the Sant Corneli Anticline, South-Central Spanish Pyrenees
}

\author{
Amanda DeLisle
}

Follow this and additional works at: https://researchrepository.wvu.edu/etd

\section{Recommended Citation}

DeLisle, Amanda, "Analysis of Paleofluids in the Sant Corneli Anticline, South-Central Spanish Pyrenees" (2016). Graduate Theses, Dissertations, and Problem Reports. 5467.

https://researchrepository.wvu.edu/etd/5467

This Thesis is protected by copyright and/or related rights. It has been brought to you by the The Research Repository @ WVU with permission from the rights-holder(s). You are free to use this Thesis in any way that is permitted by the copyright and related rights legislation that applies to your use. For other uses you must obtain permission from the rights-holder(s) directly, unless additional rights are indicated by a Creative Commons license in the record and/ or on the work itself. This Thesis has been accepted for inclusion in WVU Graduate Theses, Dissertations, and Problem Reports collection by an authorized administrator of The Research Repository @ WVU. For more information, please contact researchrepository@mail.wvu.edu. 


\title{
Analysis of Paleofluids in the Sant Corneli Anticline, South-Central Spanish Pyrenees
}

\author{
Amanda DeLisle \\ Thesis submitted to the \\ College of Arts and Sciences \\ at West Virginia University \\ in partial fulfillment of the requirements \\ for the degree of \\ Master of Science \\ in \\ Geology \\ Ryan Shackleton, Ph.D., Chair \\ Jaime Toro, Ph.D., Co-chair \\ Kathleen Benison, Ph.D. \\ Shikha Sharma, Ph.D. \\ Mark Evans, Ph.D. \\ Department of Geology and Geography \\ Morgantown, West Virginia \\ 2016
}

Keywords: Anticline, Paleofluid, Pyrenees, Vein

Copyright 2016 Amanda DeLisle 


\begin{abstract}
Analysis of Paleofluids in the Sant Corneli Anticline, South-Central Spanish Pyrenees
\end{abstract}

Amanda DeLisle

Five systematic joint sets (J1-J5) have been observed at and around the Sant Corneli anticline in the south-central Spanish Pyrenees. These joint sets have been identified and grouped primarily on observed orientations in the field by two previous studies; however, syntectonic strata and cross-cutting relationships do not fully constrain the timing of these sets. This lack of timing constraints has resulted in two differing interpretations regarding the timing of each joint set. Understanding the conditions (ie. pressure, temperature) of fracture filling cements at the time of cement formation can provide direct evidence for fluid evolution and migration at the time of formation, with direct implications regarding the timing of the fractures. The conditions of vein cement formation can be determined through detailed petrography, fluid inclusion microthermometry, and stable isotope analyses of the vein cements. Petrographic observations of the $\mathrm{J} 1$ and $\mathrm{J} 2$ sets indicate that the veins are characterized by drusy calcite cement, followed by fibrous to elongate blocky calcite cement and small blocky calcite cement, and exhibit no iron oxides. The J3, J4 and J5 veins are characterized by drusy calcite cement, small blocky calcite cement and large blocky calcite cement. Although J3 does not exhibit any iron oxides, the J4 and $\mathrm{J} 5$ samples do contain iron oxides. Late quartz cement is observed in the $\mathrm{J} 1$, J3 and J4 samples; because these samples were taken from the same stratigraphic sequence, the presence of the late quartz cement indicates that fluids became restricted at some time. Although there were significant fluid inclusions present within the vein samples analyzed, no fluid inclusion data was acquired because the fluid inclusions were too small to accurately distinguish phase changes during analyses. However, petrography of the fluid inclusions indicates that there were multiple generations of fluids passing through these veins. Carbon and oxygen stable isotope analyses indicate that the $\mathrm{J} 1$ and $\mathrm{J} 3$ sets were possibly open fracture networks, while the $\mathrm{J} 2$, J4 and J5 sets were most likely closed systems. The origins of the fluids for each joint set remains unknown, however, due to the lack of temperature data during vein formation. 


\section{Acknowledgements}

This project has been quite a challenge in so many ways, but also a great experience. I would first like to thank my advisor, Dr. Ryan Shackleton, for providing me with this project and the funding to make this research possible, and for all the guidance he's given me along the way. Also, thanks for taking me to Spain for the first time - talk about an experience I will never forget! I would also like to thank the rest of my committee, Dr. Toro, Dr. Benison, Dr. Sharma, and Dr. Evans, for all of their expertise and support they have given me throughout this research. Your input and advice have been critical in helping me gain focus on the important aspects of the research and staying on task for answering the questions at hand.

There are several others that have helped maintain my sanity throughout this project. Travis Wilson, thanks so much for all your help with my isotope samples - I owe you. Also a huge thanks to Sofia Andeskie, Patrick Frier and Emily Bausher for their support, letting me constantly bounce ideas off them and for their artistic input to the presentation of this thesis and the corresponding presentation. Patrick, you're the best pseudo-office mate anyone could ask for! Lastly, thanks to my parents and their significant others, and my brother for constantly providing the comedic humor to prevent me from going insane on a daily basis, as well as feeding me and providing copious amounts of alcohol when a distraction was needed to help me refocus. 


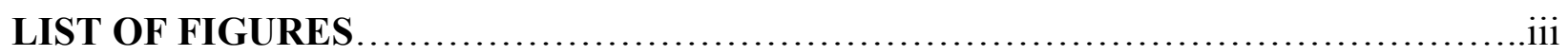

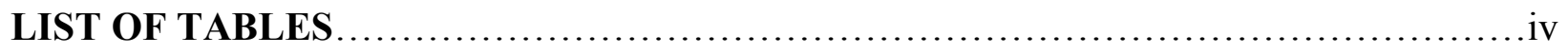

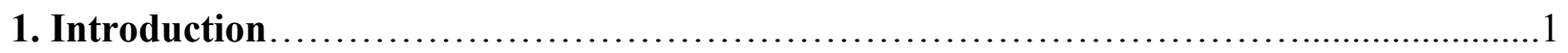

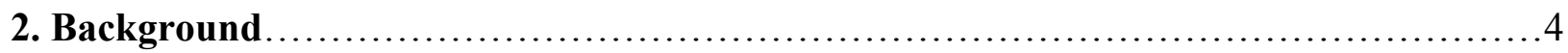

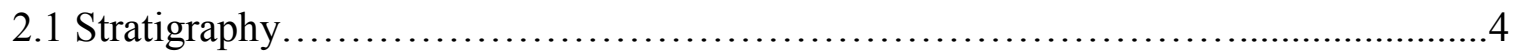

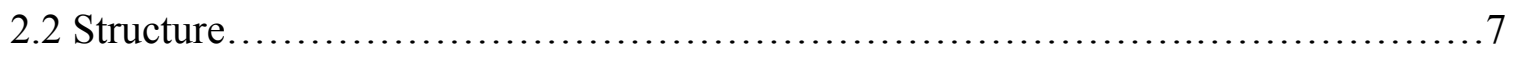

2.3 Fluid Evolution......................................................... 16

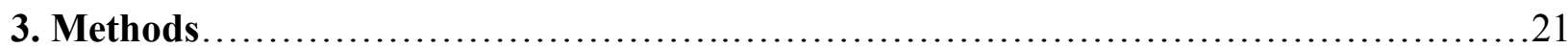

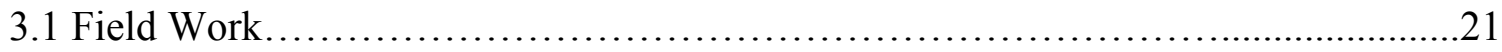

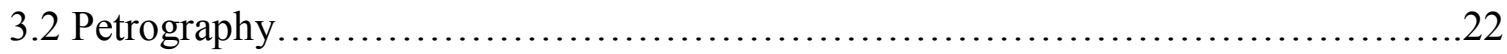

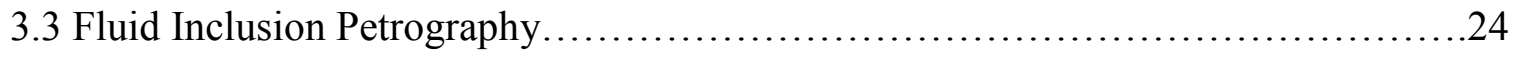

3.4 Fluid Inclusion Microthermometry.....................................27

3.5 Stable Isotope Analysis.......................................................29

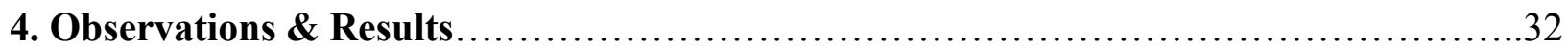

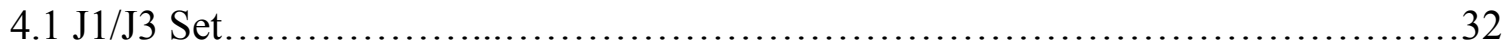

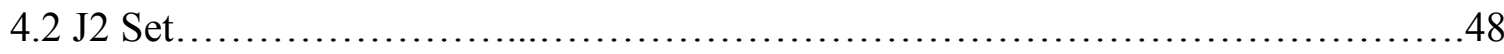

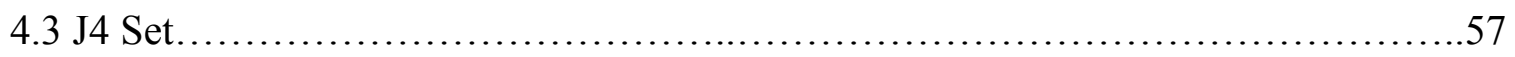

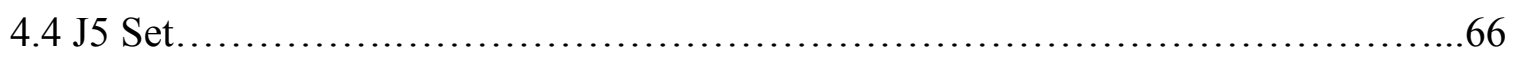

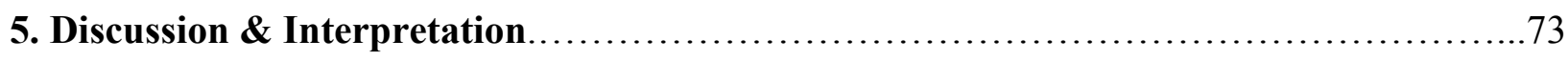

6. Summary, Conclusions, \& Future Work......................................... 81

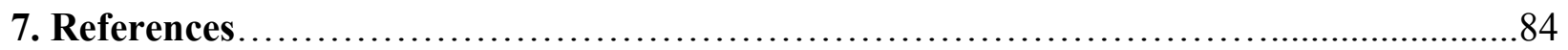

8. Appendices................................................................ 88

8.1 Appendix A: Petrographic observations.................................. 88

8.2 Appendix B: Isotope data............................................90 
List of Figures $\quad$ PAGE

1. Geologic map of the Sant Corneli- Bóixols-Nargó anticline...............................2

2. Simplified stratigraphic column of the major stratigraphic sequences.....................5

3. Simplified geologic map with cross-section...................................... 8

4. Map view of $\mathrm{J} 2$ joints........................................................ 10

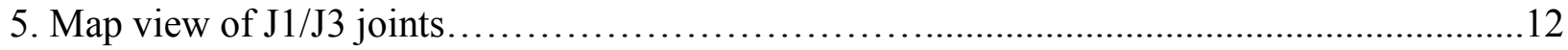

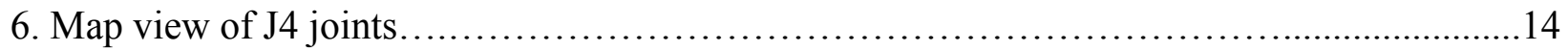

7. Map view of J5 joints..................................................... 15

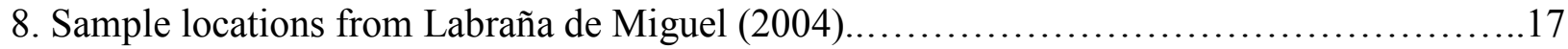

9. Isotope data from Labraña de Miguel (2004)...................................... 18

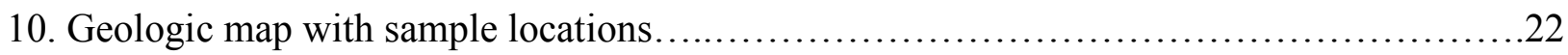

11. Examples of primary fluid inclusions in calcite.................................... 25

12. Isotope fractionation of oxygen isotopes between water and calcite...................... 31

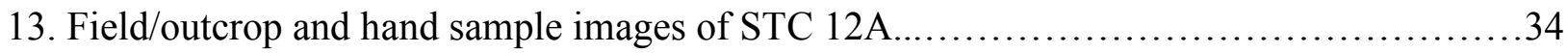

14. Field/outcrop and hand sample images of STC 12B..................................

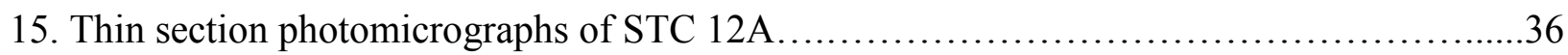

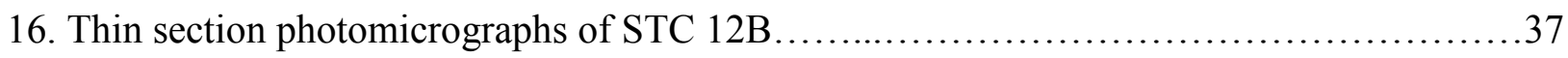

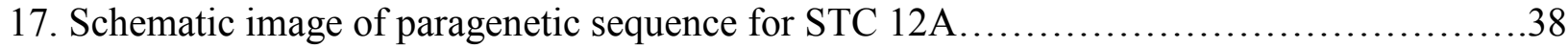

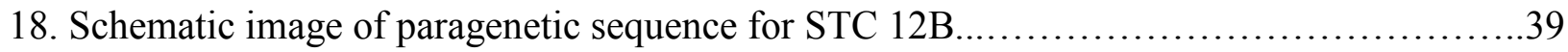

19. Fluid inclusion photomicrograph of STC 12B................................... 41

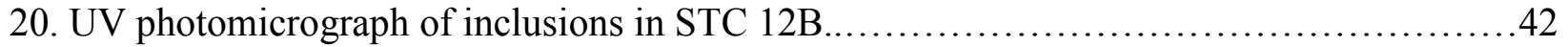

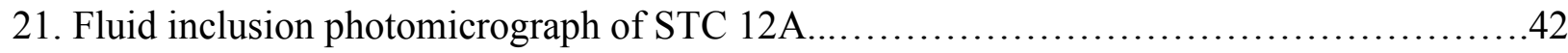

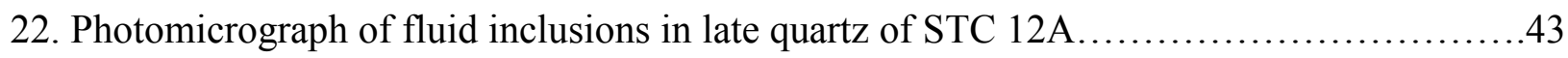

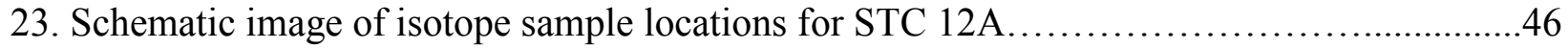

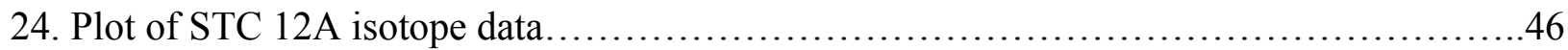

25. Schematic image of isotope sample locations for STC 12B........................47

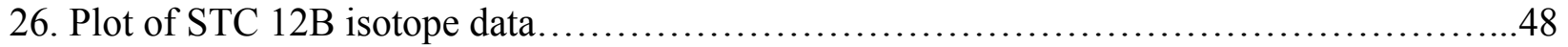

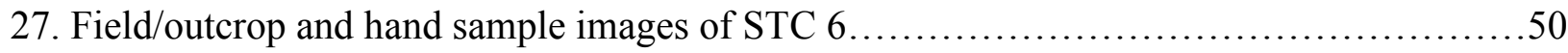




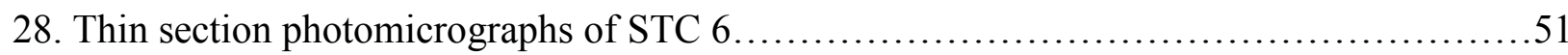

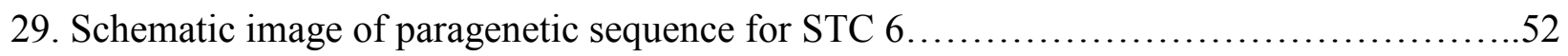

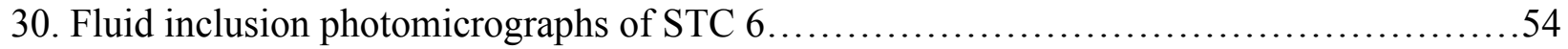

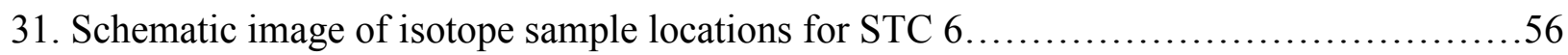

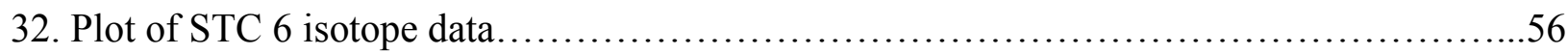

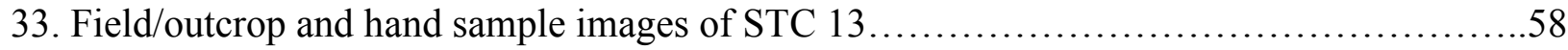

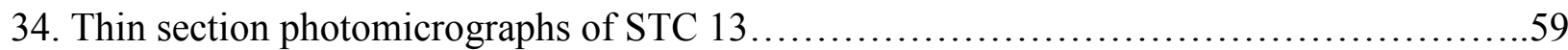

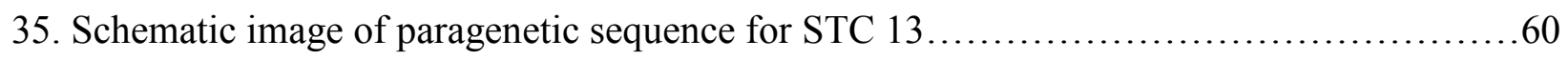

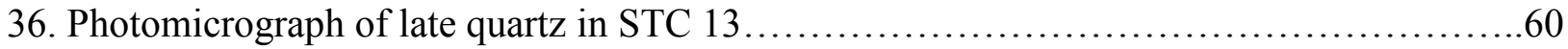

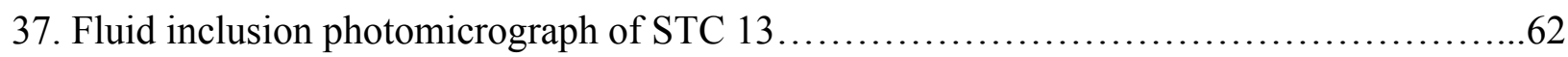

38. Fluid inclusion photomicrograph of inclusions in late quartz of STC $13 \ldots \ldots \ldots \ldots \ldots \ldots . \ldots 6$

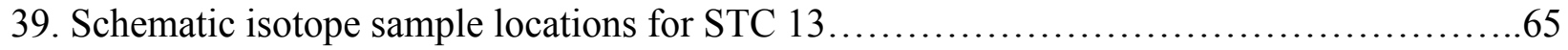

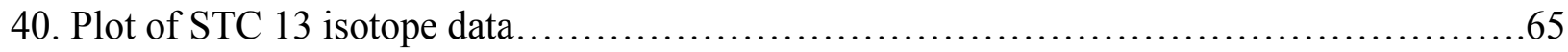

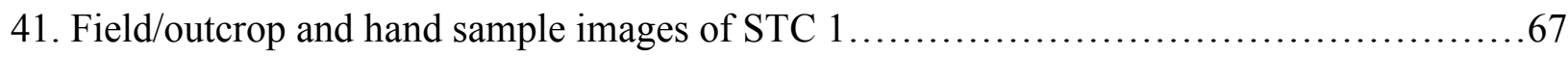

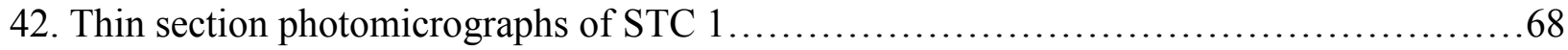

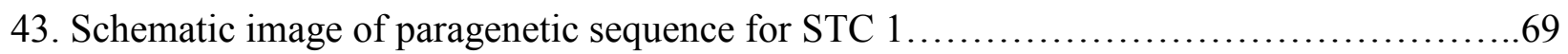

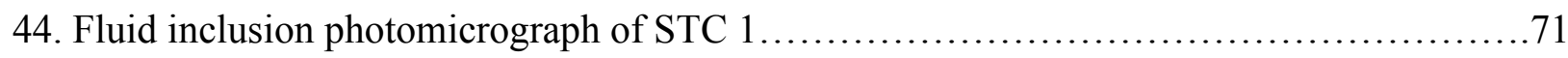

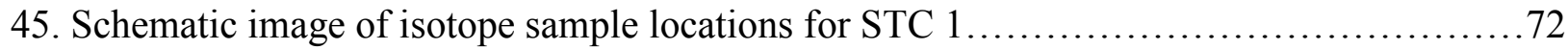

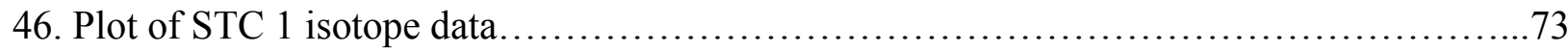

47. Summary plot of the isotope data for all samples.................................... 76 


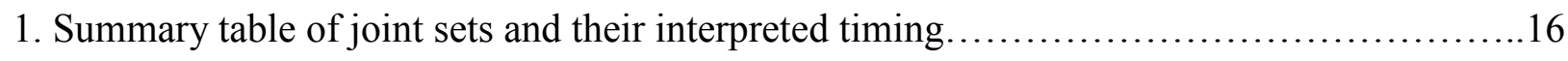

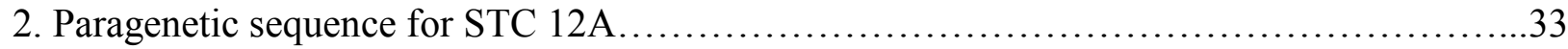

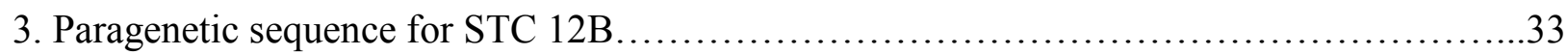

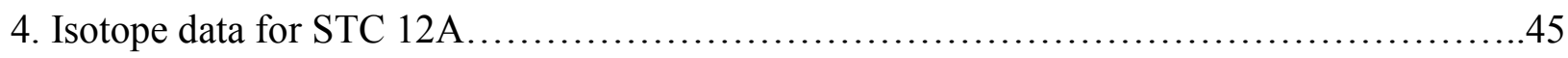

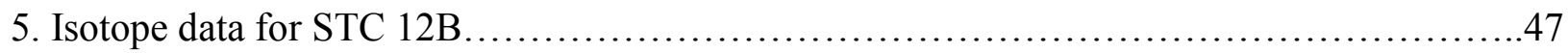

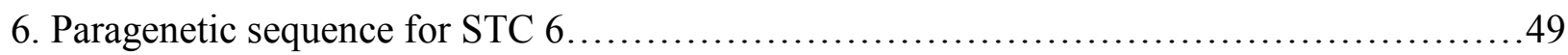

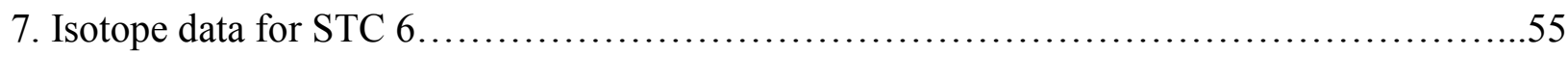

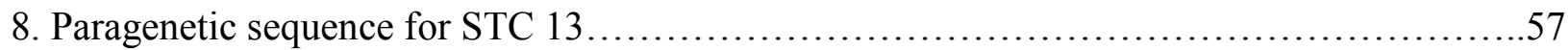

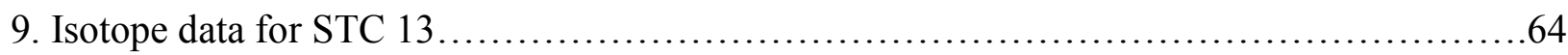

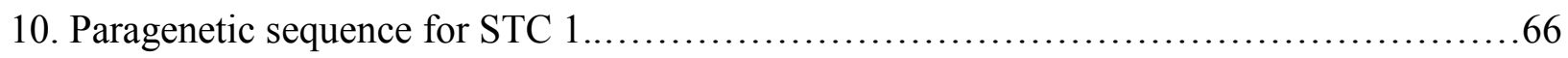

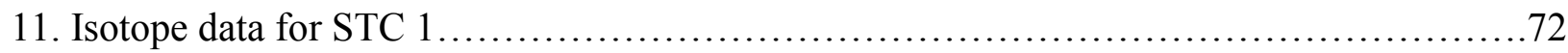

12. Calculated fluid temperatures from oxygen isotope data...............................80

13. Calculated fluid temperatures from carbon isotope data............................. 81

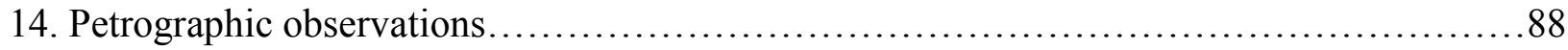

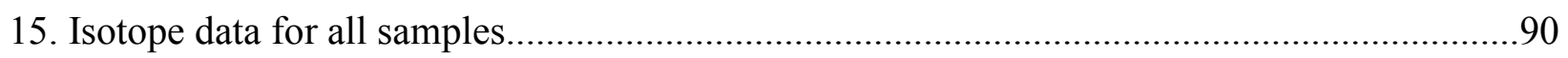




\section{Introduction}

The processes of folding and related fracturing, as well as the structures resulting from these processes, are crucial to understanding subsurface fluid migration. Fluid migration and evolution related to a fold-thrust belt have direct implications for hydrocarbon exploration because subsurface fluids may be basinal brines, meteoric waters, or hydrocarbons (Evans et al., 2014). Connectivity between fluid reservoirs during folding controls fluid distribution within a fold (Evans et al., 2012), and can be affected by dissolution or precipitation of vein cements and/or the creation of fracture networks as a fold evolves (Srivastava \& Engelder, 1990; Fischer et al., 2009; Shackleton et al., 2011). Fracture networks and other complex fluid migration pathways can cause fluid distribution to vary spatially and stratigraphically. Pre-existing fractures and faults can result in stress heterogeneity within a fold-thrust belt, affecting the interconnectivity and permeability of the fractures and faults and the ability of subsurface fluid migration (including oil and gas) (Hennings et al., 2012). An understanding of the timing and conditions of fracture formation are therefore essential to infer fluid migration pathways in the subsurface (Evans \& Fischer, 2012).

The Sant Corneli anticline in the south-central Spanish Pyrenees is an interesting place to study the temporal relationship between folding and associated fracturing (Fig. 1). Some constraints can be placed on the deformation of the anticline using the syn-tectonic strata present at the anticline, such as displaying limb rotations at different times during fold evolution. The syn-tectonic strata can also be used to help understand the evolution of fractures and other folding-related small-scale structures (Shackleton et al., 2011). However, the timing of the fractures recognized within the anticline are not fully constrained by the syn-tectonic strata. Several systematic joint sets have been observed in the Sant Corneli anticline and surrounding 
area by Shackleton et al. (2011) and Tavani et al. (2011), but the relative timing relationships of these joint sets observed in the field are ambiguous. Cross-cutting and joint termination relationships cannot fully distinguish the relative timing relationships due to the large number of joint sets that don't appear to have similar timing across the anticline when grouped by orientation.

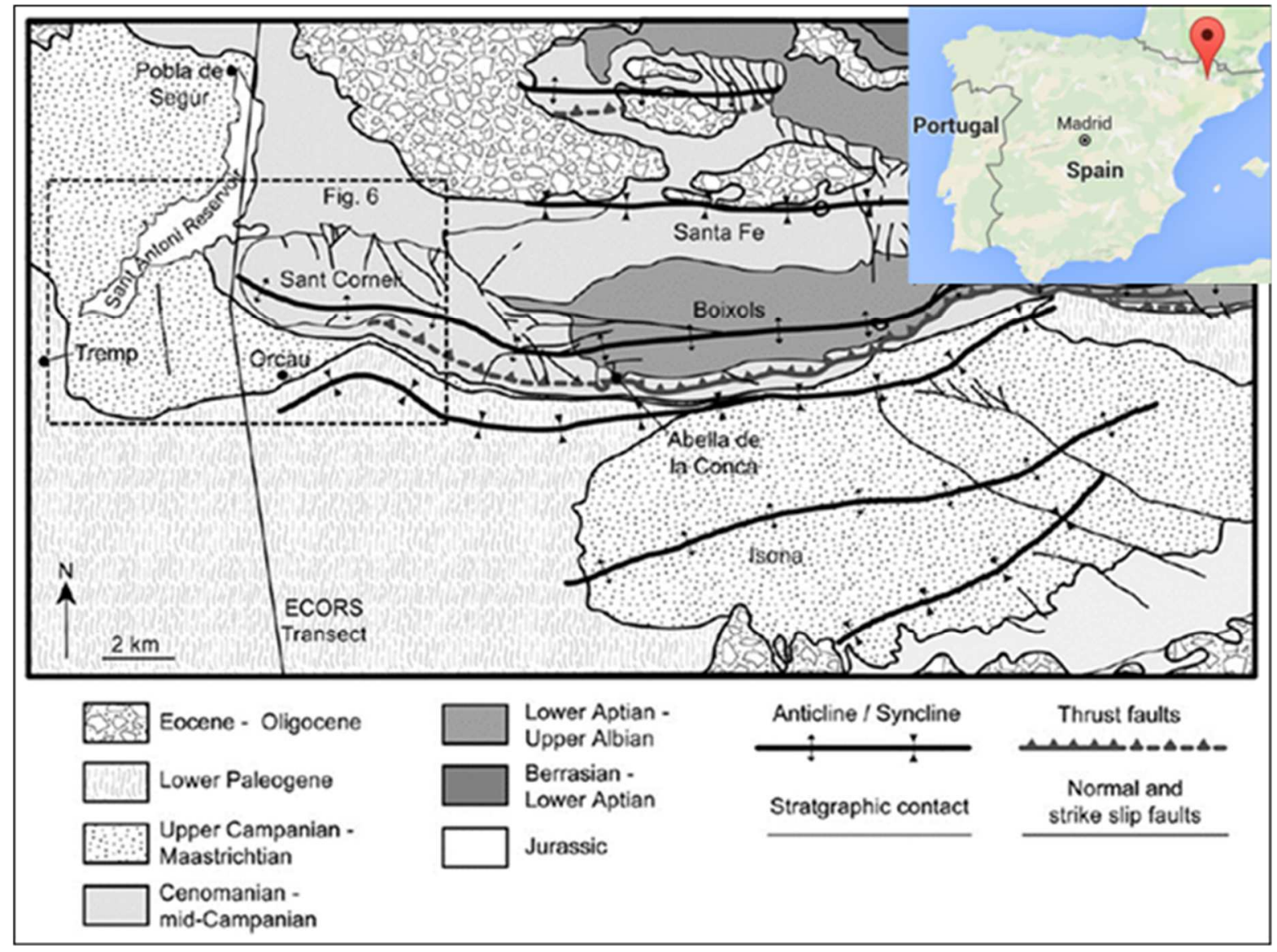

Figure 1. Geologic map of the Sant Corneli-Bóixols-Nargó anticline. (Shackleton et al., 2011; modified from Bond \& McClay, 1995). The location of the Sant Corneli-Bóixols-Nargó anticline in relation to Spain is indicated by the red pin in the inset map of Spain. Area in the dotted box is shown in Figure 6. (Inset map courtesy of Google Earth).

Previous authors have used detailed vein mineral petrography, fluid inclusion microthermometry and stable isotope techniques as useful tools for understanding fracture paragenesis and fluid evolution (Lee et al., 1997; Evans \& Battles, 1999; Evans, 2000; Anastasio 
et al., 2004; Lefticariu et al., 2005; Travé et al., 2007; Fischer et al., 2009; Evans, 2010;

Beaudoin et al., 2011; Fitz-Diaz et al., 2011; Evans et al., 2012; Evans et al., 2014). The type and degree of mineralization of vein cements can be characterized through careful, detailed petrographic observations and mineral paragenesis (Evans, 2000). Petrographic observations could also provide correlations between fracturation and fluid flow (Travé et al., 2007). Because veins can grow at different stages of development of the local host structures with which they are associated in fold-thrust belts, petrographic observations could help define the relationships between the veins associated with each joint set (Fitz-Diaz et al., 2011).

Fluids can become trapped as inclusions in veins as minerals precipitate along open fractures and faults if crystal growth of the mineral(s) is rapid enough. These trapped fluid inclusions can provide data regarding the conditions of the fluids during entrapment, including temperature, pressure, and composition, when analyzed (Goldstein \& Reynolds, 1994; Evans \& Battles, 1999; Fischer et al., 2009; Evans, 2010; Fitz-Diaz et al., 2011; Evans et al., 2012; Evans et al., 2014).

Compositional information of past vein fluids can also be acquired through carbon and oxygen stable isotope analyses (Lee et al., 1997; Anastasio et al., 2004; Travé et al., 2007; Beaudoin et al., 2011). Carbon and oxygen isotopic composition data could help indicate whether fluids originated as basinal brines, or oceanic or meteoric waters, as well as whether fluids were restricted or mixing between multiple stratigraphic layers and structures (Lefticariu et al., 2005; Travé et al., 2007; Evans et al., 2012; Evans et al., 2014).

The goal of this project is to provide further constraints on the relative timing of mineralized joints in the Sant Corneli anticline by analyzing the composition and temperatures of the mineralizing fluids. Petrographic, stable isotope, and fluid inclusion analyses of vein cements 
filling these joints could indicate common features or differences between each joint set, and therefore potentially provide further timing constraints on the deformation of the anticline. Stable isotope analyses of the vein cements could differentiate between fluid sources within the different joint sets and whether the fractures were part of an open or closed fluid network. Fluid inclusion data could potentially indicate whether the cements of certain joint sets were precipitated under similar pressure and temperature conditions, and therefore whether those joint sets were formed at different or similar times.

\section{Background}

The collision between the European and Iberian plates during the Late Cretaceous to Early Miocene resulted in the formation of the Spanish Pyrenees. The Iberian plate became partially subducted to the north during the convergence of the two plates (Simó, 1989; Guillaume et al., 2008; Trave et al., 2007), and resulted in the inversion of the earlier lower Cretaceous Organyà extensional basin (Berástegui et al., 1990; Bond \& McClay, 1995; McClay et al., 2004). This inverted extensional basin was therefore incorporated into the Pyrenean thrust sheets. Evidence for the structural history of the Sant Corneli- Bóixols-Nargó anticline has been recorded by the syn-tectonic Late Cretaceous-Oligocene stratigraphy that overlies the anticline (Bond \& McClay, 1995; Mencos et al., 2010).

\subsection{Stratigraphy}

Triassic to mid-Cretaceous terrestrial and carbonate rocks of the inverted Organyà basin are found in the core of the Sant Corneli anticline, as evidenced by well data from wells located in the Sant Corneli and Boixols anticlines (Simó, 1989; Bond \& McClay, 1995). At the surface 
of the anticline, however, only Early Cretaceous (Santonian) to modern-aged rocks are exposed (Fig. 2).

The Sant Corneli sequence overlies the core of the anticline, and is composed of platform carbonates and calcarenites. The deposition of this sequence represents the edge of a basin that, during the time of deposition, deepened to the northwest (Simó, 1989). The Sant Corneli sequence is overlain by the Vallcarga sequence, separated by a regional angular unconformity (Fig. 2). The Vallcarga sequence is composed of turbiditic marls, limestones and clays in the study area (Nagtegaal et al., 1983; Bond \& McClay, 1995).

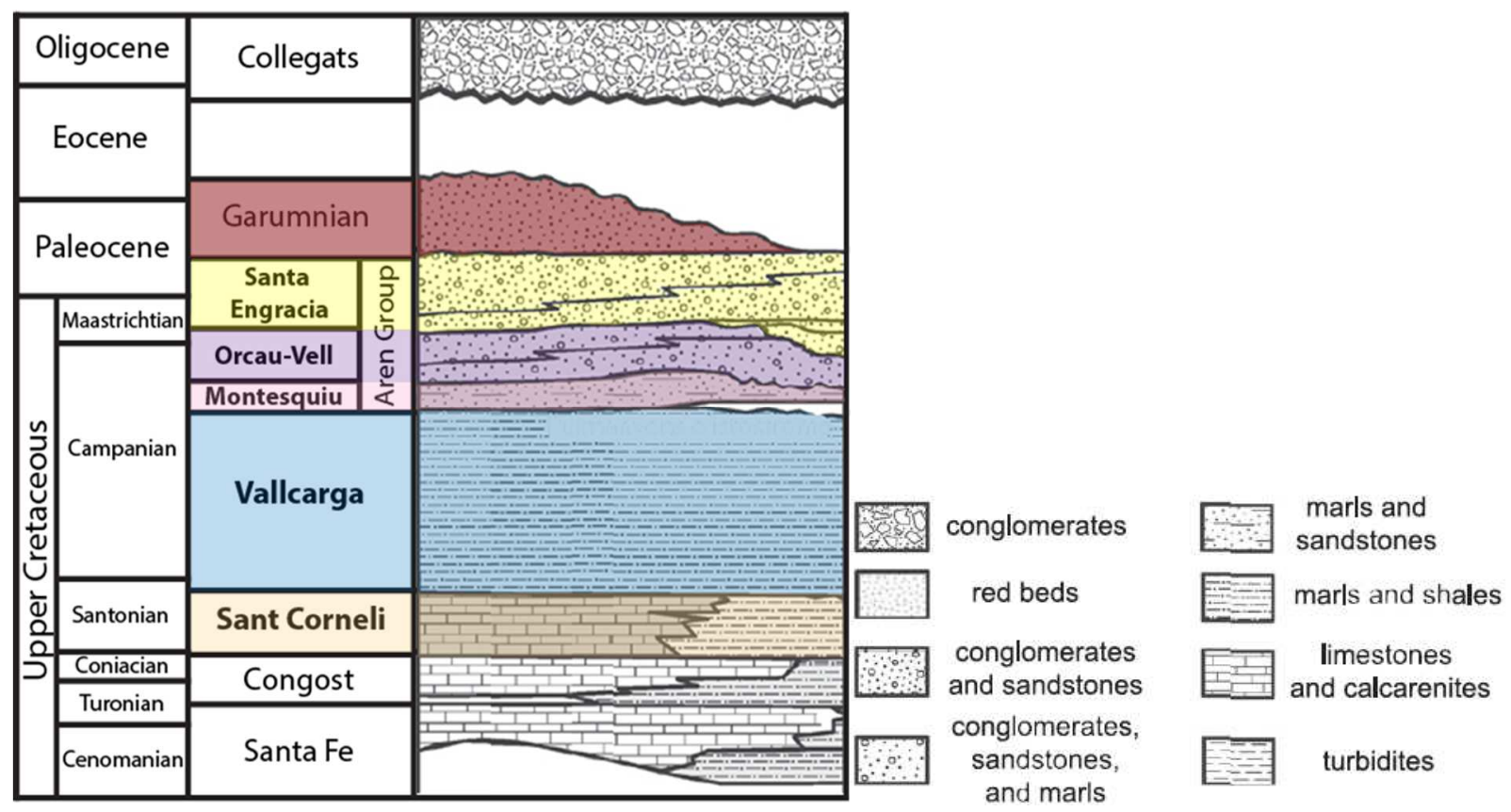

Figure 2. Simplified stratigraphic column of the major stratigraphic sequences. Names in bold represent sequences discussed in the text, while other names refer to formation or facies names unless otherwise specified (modified from Shackleton et al., 2011).

The Aren group overlies and interfingers with the Vallcarga sequence, and has undergone many different subdivisions by different authors. The naming conventions set by Déramond et al. (1993), revised by Guillaume et al. (2008), will be used here. The Montesquiu sequence, 
marking the base of the Aren group, is characterized by olistoliths and growth faulting. The Puimanyons olistostrome, which marks the end of Vallcarga deposition, was interpreted by Simó et al. (1985) to represent basin margin collapse, potentially resulting from the initial thrusting of the Bóixols thrust sheet and the amplification of Sant Corneli anticline (Guillaume et al., 2008; Shackleton et al., 2011). The Salas marls overly the olistoliths and growth faulting, representing basin fill from a northwest progradation of nearshore to offshore siliciclastics (Nagtegaal et al., 1983; Simó et al., 1985). At Sant Corneli, the Montesquiu sequence is cut by a karst surface with locally incised valleys, creating an erosional subaerial surface that separates the Montesquiu sequence from the overlying Orcau-Vell sequence (Nagtegaal et al., 1983; Simó et al., 1985; Guillaume et al., 2008). The Orcau-Vell sequence is composed of tide-influenced bioclastic bars in a rapidly deepening basin to the west that transitions into fluvial channel fill in the east (Simó, 1989; Déramond et al., 1993; Guillaume et al., 2008; Shackleton et al., 2011).

Westward propagation of the Sant Corneli anticline and a concurrent increase in the slope gradient has been interpreted to be the cause of the destabilization of the Orcau-Vell sequence (Guillaume et al., 2008), resulting in a gravitational normal fault at the western tip of the anticline. The deposition of the overlying Santa Engracia sequence was channeled by a depression created by this gravitational normal fault (Déramond et al., 1993; Guillaume et al., 2008). Therefore, the base of the Santa Engracia sequence is partially formed by a gravity-driven fault as well as by an erosional surface consisting of the underlying Orcau-Vell sequence (Simó et al., 1985; Simó, 1989; Guillaume et al., 2008; Shackleton et al., 2011). It should be noted, however, that there is no outcrop evidence for the gravity-driven fault; it has been interpreted solely based on observations of an abrupt facies change across an apparent N-NW striking boundary (Déramond et al., 1993; Guillaume et al., 2008). 
The Santa Engracia sequence is divided into upper and lower portions. The lower Santa Engracia contains Gilbert-type delta and turbiditic quartz-rich slope deposits. The upper surface of these deposits is oxidized, representing significant subaerial erosion and base level fall (Guillaume et al., 2008). The upper Santa Engracia consists of a deltaic highstand systems tract overlying a carbonate marine transgressive systems tract, which suggests base level rise

following subaerial erosion (Déramond et al., 1993; Guillaume et al., 2008). The Santa Engracia sequence is overlain by the Garumnian facies, the youngest sequence in the study area. The Garumnian unit is composed of terrestrial fluvial deposits and are interpreted to have been deposited during a relatively quiet tectonic period (Nagtegaal et al., 1983; Simó et al., 1985; Simó, 1989; Déramond et al., 1993; Bond \& McClay, 1995; Guillaume et al., 2008; Shackleton et al., 2011).

\subsection{Structure}

The uppermost thrust sheet of the south-central Spanish Pyrenees is the Bóixols thrust (Tavani et al., 2011). The Bóixols thrust sheet is a nearly 40-kilometer long, east-west trending and south-vergent thrust that formed above detachments in Triassic evaporites (Deramond et al., 1993; Bond \& McClay, 1995; Guillaume et al., 2008; Shackleton et al., 2011). This thrust sheet is characterized by large kilometer-scale folds with a general east-west strike (Bond \& McClay, 1995; Tavani et al., 2011). 

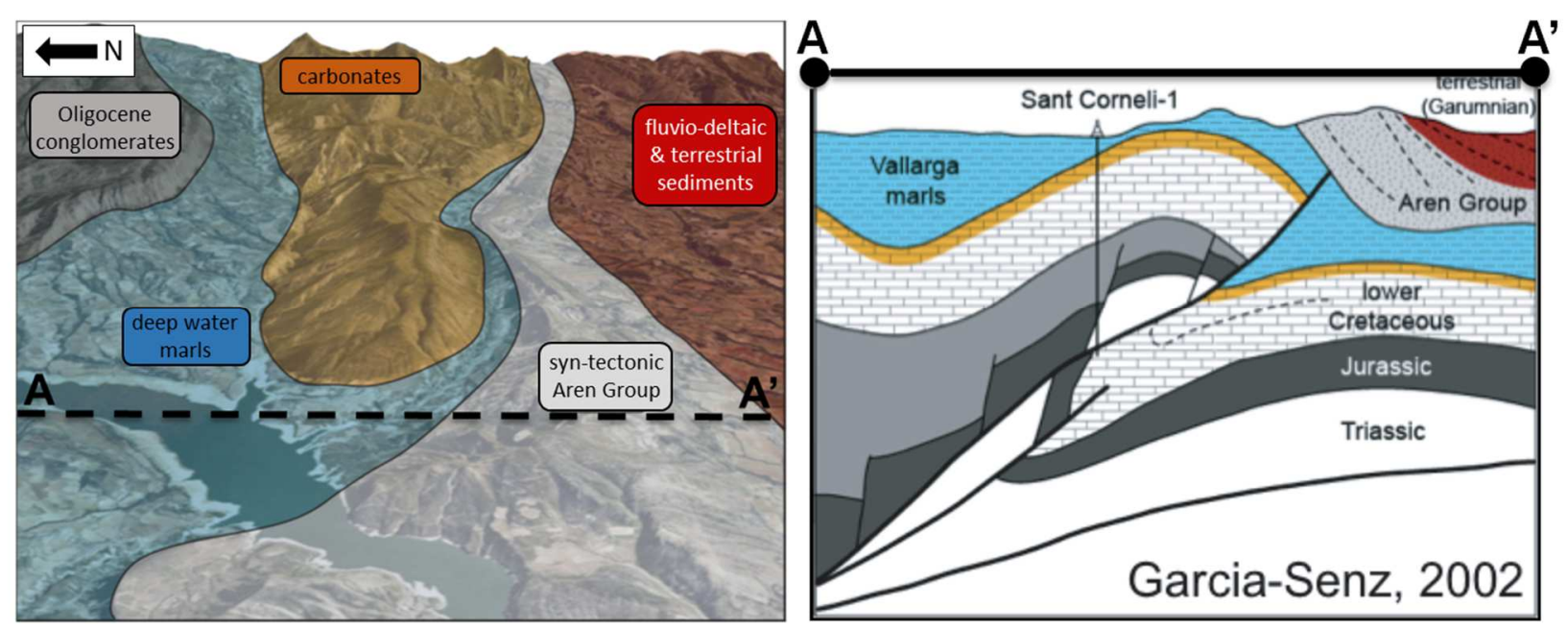

Figure 3. A simplified geologic map of the Sant Corneli anticline (left) with an associated crosssection (right). The geologic map is looking east at the nose of the anticline (modified from Shackleton et al., 2013; Garcia-Senz, 2002).

The Sant Corneli anticline is characterized by a westward-plunging, asymmetric shape and forms the westward termination of the Bóixols thrust sheet (Shackleton et al., 2011; Tavani et al., 2011). A three-dimensional geologic map of the Sant Corneli anticline, along with a corresponding cross-section, is shown in Figure 3 to illustrate the structure of the anticline. The geomorphic expression of the anticline is largely defined by the Sant Corneli sequence, which is folded into an open, asymmetric anticline at the surface with a steep, westward plunge (Shackleton et al., 2011). Bedding in the backlimb of the anticline is relatively planar, while the bedding in the forelimb is much steeper. There is relatively little faulting or kinking within the transition from forelimb to backlimb along the fold nose, supported by a continuous outcrop trace of the contact between the overlying marls and the Sant Corneli sequence (Shackleton et al., 2011). This transition from forelimb to backlimb in the core of the anticline, however, is much more abrupt and many geologic maps include abrupt hinges or faults in the fold core to account for abrupt dip changes from forelimb to backlimb (Mencos et al., 2010; Mencos et al., 2011; Shackleton et al., 2011). 
Three main sets of faults have been recognized in and around the Sant Corneli anticline. Map-scale normal faults striking NNE to NNW have been observed between the cylindrical part of the anticline to the east and the fold nose. The faults in the forelimb have a NNE orientation while the faults in the backlimb have a NNW orientation (Shackleton et al., 2011; Tavani et al., 2011). These faults are best exposed in the Sant Corneli sequence in the backlimb, but are also visible in the forelimb, nose and backlimb in the Sant Corneli, Vallcarga and Montesquiu sequences (Shackleton et al., 2011). These faults are generally at a low angle in the Aren marls and Vallcarga sequence, but are steeper in the Sant Corneli sequence. Although the faults in the Sant Corneli are mineralized with sparry calcite only, the faults in the Vallcarga and Aren marl units are generally filled with thick calcite and most contain iron oxidation haloes and goethite mineralization of the surrounding wall rock (Shackleton et al., 2011).

Another set of WNW striking normal faults are found in the backlimb of the Sant Corneli anticline. These faults have been described as polyphasic, meaning they display both right-lateral and normal movement, by Tavani et al. (2011). However, Shackleton et al. (2011) described these faults as displaying normal displacement only. The WNW striking normal faults are observed at both map-scale and smaller scales, and are filled with calcite and hematite cements (Shackleton et al., 2011).

Several joint sets have been recognized in the Sant Corneli anticline (Fig. 4-7) and are summarized in Table 1 at the end of this section. Descriptions of the joint sets will follow the naming conventions set in Shackleton et al. (2011) for simplicity. NNW striking joints (J2) are seen in the Aren group but are not seen in the underlying Sant Corneli sequence (Fig. 4). The J2 set is characterized by planar and very systematic joints filled with sparry and locally fibrous calcite cement (Shackleton et al., 2011). These joints are typically up to a few meters in length 
and height, with very systematic spacing and exhibit almost no variation in orientation

(Shackleton et al., 2011).

There are multiple interpretations regarding the formation of this joint set (see Table 1).

Shackleton et al. (2011) proposed the formation of these joints was locally due to a N-NW slump fault because joints of the same orientation as the J2 set aren't observed in the Sant Corneli sequence. However, Tavani et al. (2011) have suggested the formation of these joints in response to N-NW oriented compression far-afield.

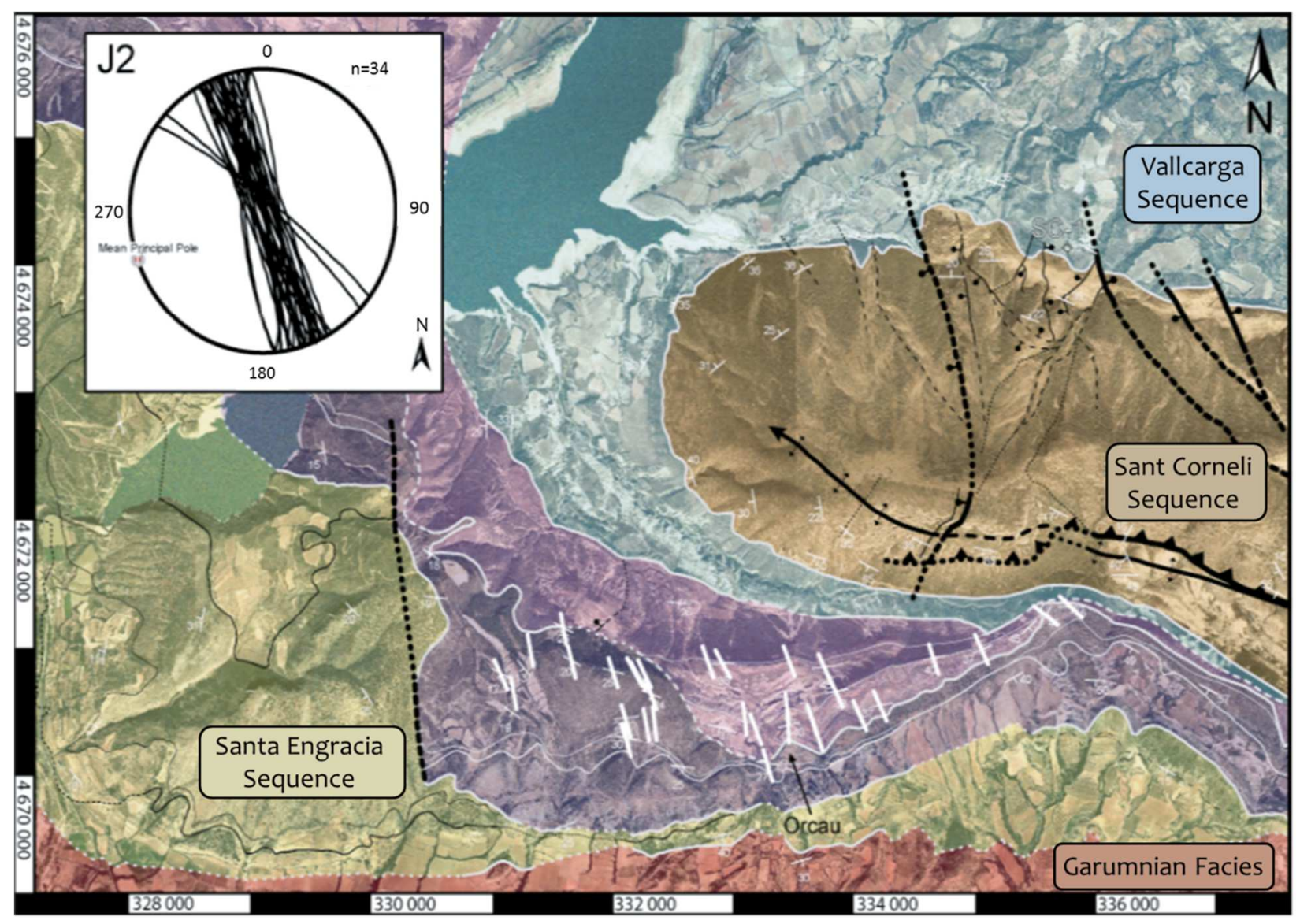

Figure 4. Map view of J2 joints (from Shackleton et al., 2011). Joints are represented by the bold white lines. All joint orientations have been rotated to horizontal. This map illustrates the lack of J2 joints observed in the formations underlying the Aren group. Shackleton et al. (2011) interpreted the formation of these joints to have occurred locally due to slump faulting; Tavani et al. (2011) suggested the formation of J2 joints was due to NNW-oriented compression far-afield. 
Two more joint sets $(\mathrm{J} 1 / \mathrm{J} 3)$, characterized by orientations at large angles to bed strike, are observed in the Sant Corneli anticline (Fig. 5). In the Aren group, these joints are NNE striking calcite-filled joints (Shackleton et al., 2011). Field observations indicate some of these joints (J1) are cross-cut by the $\mathrm{J} 2$ joints, therefore predating the $\mathrm{J} 2$ set. However, other joints at this orientation (J3) are observed cross-cutting the $\mathrm{J} 2$ joints, indicating that they postdate the $\mathrm{J} 2$ set (Shackleton et al., 2011). These joints, both J1 and J3, are grouped together because the crosscutting relationships aren't always present to determine their relative timing. Both J1 and J3 joints are characterized by variable orientations, lengths and heights of one meter or less, and are localized near faults (Shackleton et al., 2011).

Tavani et al. (2011) interpreted the formation of these NNE-oriented faults and joints to correspond to a pre-folding extensional stage, which would indicate that both $\mathrm{J} 1$ and $\mathrm{J} 3$ joints at the NNE-orientation pre-date the formation the J2 set (highlighted in Fig. 5). It should be noted here that the interpretation of Tavani et al. (2011) does not include the NW-striking J1/J3 joints observed on the backlimb of the anticline. In contrast to the interpretation of Tavani et al. (2011), Shackleton et al. (2011) suggest the J1 joints and normal faults formed resulting from a combination of E-W stretching and basin margin collapse at the onset of fold propagation into the area, while the $\mathrm{J} 3$ joints formed potentially due to normal fault reactivation during intermediate stages of folding due to flexure along the axis of the fold (see Table 1). Shackleton et al. (2011) also suggest flexure along the axis would account for the sharp change in plunge of the fold axis, where it steepens abruptly from nearly horizontal in the western portion to $\sim 25^{\circ}$ where the Sant Corneli sequence outcrops below the Vallcarga sequence.

A joint set similar to the $\mathrm{J} 1 / \mathrm{J} 3$ sets has also been observed in the Sant Corneli sequence. These joints have a NNW orientation in the backlimb and a NNE orientation in the forelimb, and 
they are nearly perpendicular to bed strike. The presence of these similar joints in the Sant Corneli sequence, along with the $\mathrm{J} 1 / \mathrm{J} 3$ set present in the Aren group, suggest that the joints formed due to similar mechanisms within both stratigraphic horizons (Shackleton et al., 2011). These calcite-filled NNE and NNW joints in the Sant Corneli sequence are associated with faults oriented similar to the $\mathrm{J} 1 / \mathrm{J} 3$ set and are sub-perpendicular to the fold axis (Shackleton et al., 2011). This joint set consistently pre-dates bed-oblique joint sets similar to how the J1/J3 joints pre-date the $\mathrm{J} 4 / \mathrm{J} 5$ joints and also has sparry calcite fill similar to the $\mathrm{J} 1 / \mathrm{J} 3$ joints, providing more evidence that these joints and the J1/J3 set are likely related (Shackleton et al., 2011).

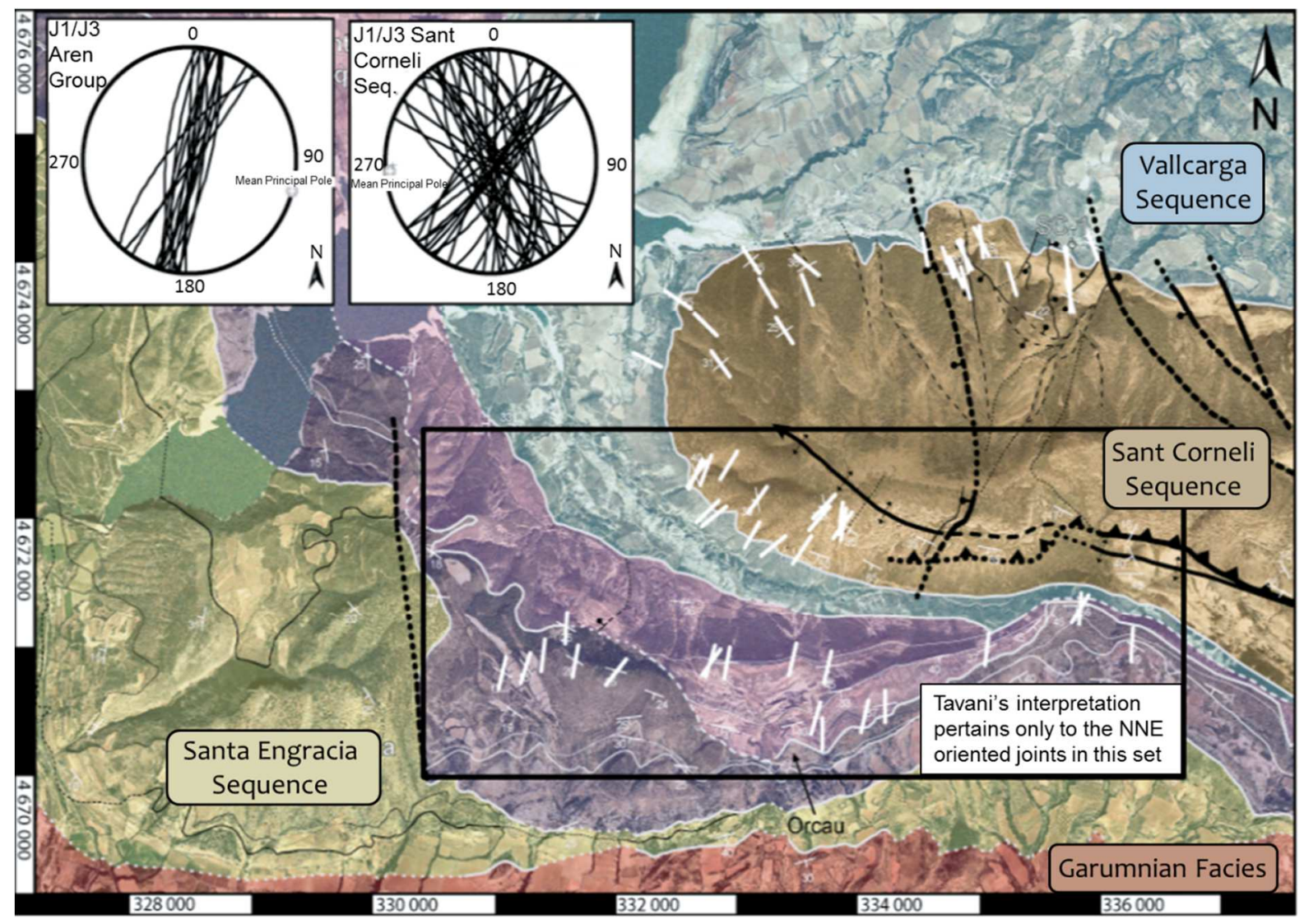

Figure 5. Map view of the J1/J3 joints (modified from Shackleton et al., 2011). Joints are shown as the bold white lines. All joint orientations have been rotated to horizontal. The black box indicates the $\mathrm{J} 1 / \mathrm{J} 3$ joints Tavani et al. (2011) interpreted to have formed due to have formed prior to the start of folding. Shackleton et al. (2011) interpreted the J1 joints to pre-date the J2 joints and formed due to E-W extension and basin margin collapse while the J3 joints formed due to the reactivation of normal faults during folding. 
Two sets of bed strike-oblique joints with differing orientations but with similar iron oxidation "haloes" defined by reddish weathering of calcite cement and adjacent wall rock have been interpreted by Shackleton et al. (2011). These joint sets appear to be the last two generations of jointing at the Sant Corneli anticline (see Table 1). One set of joints (J4), oriented WNW, are among the most systematic in the Aren group (Fig. 6) (Shackleton et al., 2011). Characteristic features of this joint set include iron oxidation and goethite mineral staining in and along the wall rock adjacent to the fractures. The Aren group and underlying marls contain J4 joints that consistently post-date both the J1/J3 and J2 joint sets (Shackleton et al., 2011). Bed strike-oblique joints with local calcite cement in the forelimb of the Sant Corneli anticline are correlated with the WNW striking joints in the Aren group. However, these bed strike-oblique joints rotate in strike as bed strike rotates around the anticline, which is the primary evidence for the fold-fracture relationship at Sant Corneli (Shackleton et al., 2011). Bed strike-oblique joints associated with the $\mathrm{J} 4$ set are characterized by local calcite cement that is relatively thin if not absent altogether, and also exhibit local mineralization with reddish iron oxidation and goethite mineral staining. J4 joints consistently cross-cut the J1/J3 joints (Shackleton et al., 2011). 


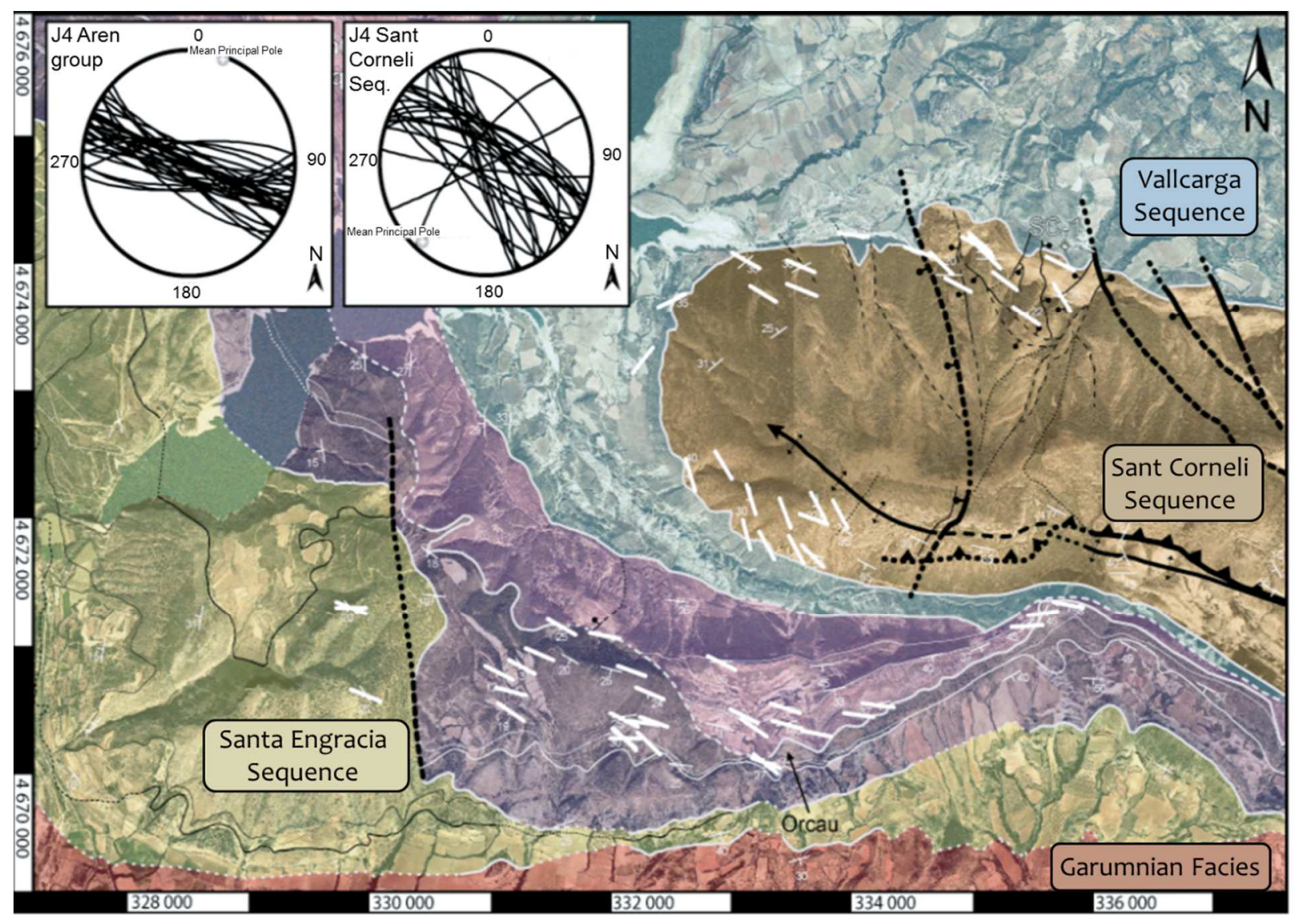

Figure 6. Map view of J4 joints (Shackleton et al., 2011). Joints are represented as the bold white lines. All joint orientations have been rotated to horizontal. Shackleton et al. (2011) interpreted the formation of these joints to be due to flexure of the anticline during the main stages of folding; Tavani et al. (2011) interpreted the formation of the J4 joints to be a result of a prefolding extensional stage.

ENE-striking calcite-cemented joints (J5) characteristically similar to the J4 set are found in the Aren group (Fig. 7). J5 joints exhibit similar iron oxidation and goethite mineralization but are typically more poorly developed than the WNW-striking joints. Shackleton et al. (2011) observed these joints locally cross-cutting the J4 set, but suggest that these two sets may be coeval. There is a calcite-cemented joint set characteristically similar to the J4 set also observed in the Sant Corneli sequence. J5 joints post-date the $\mathrm{J} 1 / \mathrm{J} 3$ set and are locally calcite-cemented with associated iron oxidation (Shackleton et al., 2011). 
Tavani et al. (2011) and Shackleton et al. (2011) both observed the J4 and J5 joint sets; however, although both agree on the formation of the $\mathrm{J} 5$ set, there is a disagreement regarding the formation of the J4 set. Shackleton et al. (2011) interpreted both the J4 and J5 sets to have formed due to flexure of the anticline during the main stage of folding, supported by the consistently changing orientation of the joints relative to local bed strike. While Tavani et al. (2011) agree that the J5 set formed during folding, Tavani et al. (2011) suggest that the J4 set formed during a pre-folding extensional stage (see Table 1).

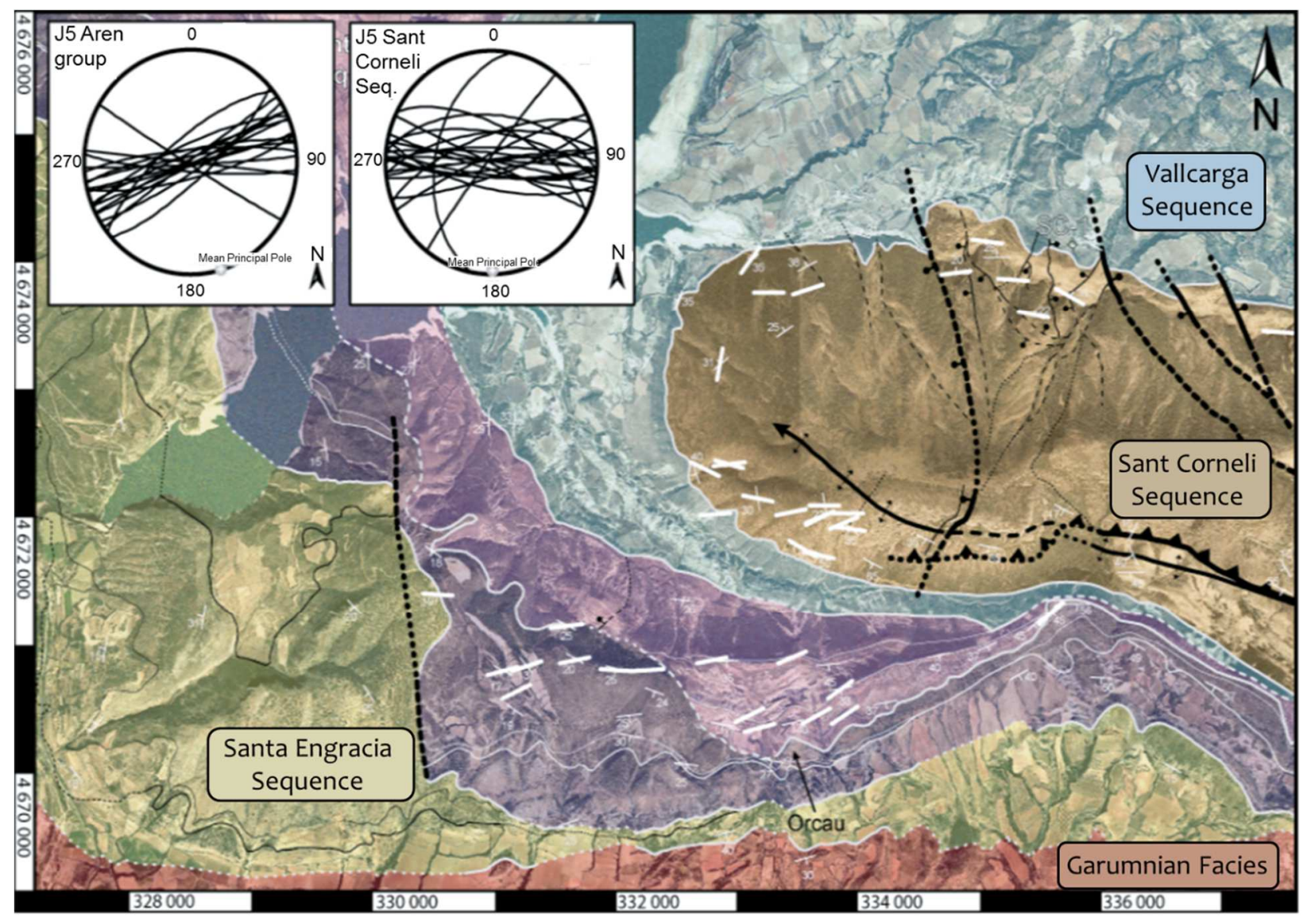

Figure 7. Map view of the J5 joints (Shackleton et al., 2011). Joints are shown as the bolded white lines. All joint orientations have been rotated to horizontal. Shackleton et al. (2011) and Tavani et al. (2011) agree that this joint set formed during folding. 


\begin{tabular}{|c|c|c|c|c|}
\hline \multicolumn{5}{|c|}{ Summary of observed joint sets and their interpreted timing } \\
\hline Joint Set & Stratigraphic Unit & Orientation & Shackleton et al. (2011) & Tavani et al. (2011) \\
\hline \multirow[t]{2}{*}{$\mathrm{J} 1 / \mathrm{J} 3$} & Aren Group & NNE & \multirow{2}{*}{$\begin{array}{l}\mathrm{J} 1-\text { combination of pre-folding } \\
\text { extension and basin margin collapse } \\
\text { at the onset of folding } \\
\mathrm{J} 3 \text { - during folding }\end{array}$} & \multirow[b]{2}{*}{$\begin{array}{l}\text { pre-folding extension (NNE-oriented } \\
\text { joints only) }\end{array}$} \\
\hline & Sant Corneli Sequence & $\begin{array}{l}\text { NNE (forelimb) } \\
\text { NNW (backlimb) }\end{array}$ & & \\
\hline $\mathrm{J} 2$ & Aren Group & NNW & locally due to NNW slump faulting & NNW compression far-afield, pre-folding \\
\hline \multirow[t]{2}{*}{ J4 } & Aren Group & WNW & \multirow{2}{*}{ during folding } & \multirow{2}{*}{ pre-folding extension } \\
\hline & Sant Corneli Sequence & NW & & \\
\hline \multirow[t]{2}{*}{ J5 } & Aren Group & ENE & \multirow{2}{*}{ during folding } & \multirow{2}{*}{ during folding } \\
\hline & Sant Corneli Sequence & ENE & & \\
\hline
\end{tabular}

Table 1. Summary of observed joint sets at the Sant Corneli anticline. This table includes timing interpretations by both Shackleton et al. (2011) and Tavani et al. (2011) for comparison.

\section{$\underline{2.3 \text { Fluid Evolution }}$}

Fluid evolution in the Sant Corneli-Boixóls anticline has not been studied extensively. Labraña de Miguel (2004) examined the origin and evolution of fluids circulating through the fractures and how the stages of fracturing related to the evolution of the anticline. Calcite vein samples were collected from a thrust fabric at the Boixols thrust at Abella de la Conca (samples 9 and 4) and from a normal fault within that thrust (samples 6 and 6-2), as well as from along one of the normal faults radiating from the crest of the Boixols anticline that are parallel to the $\mathrm{J} 1$ joints (sample 14) (see Fig. 8 for locations of each sample) for isotope and fluid inclusion analyses (Labraña de Miguel, 2004). Isotope data for all samples is shown in Figure 9. 


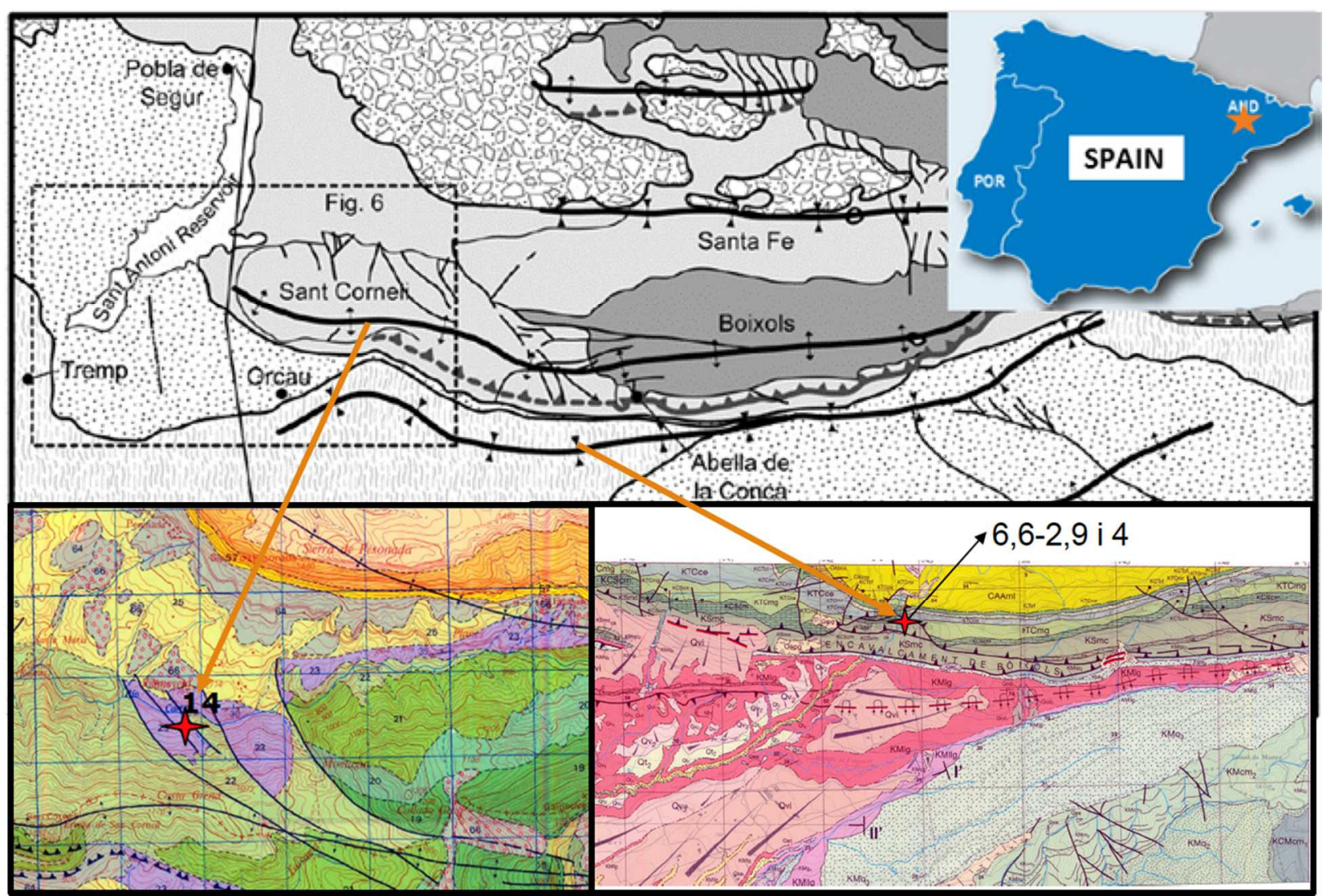

Figure 8. Sample locations from Labraña de Miguel (2004) shown in relation to the geologic map of the current study area in Figure 1. 


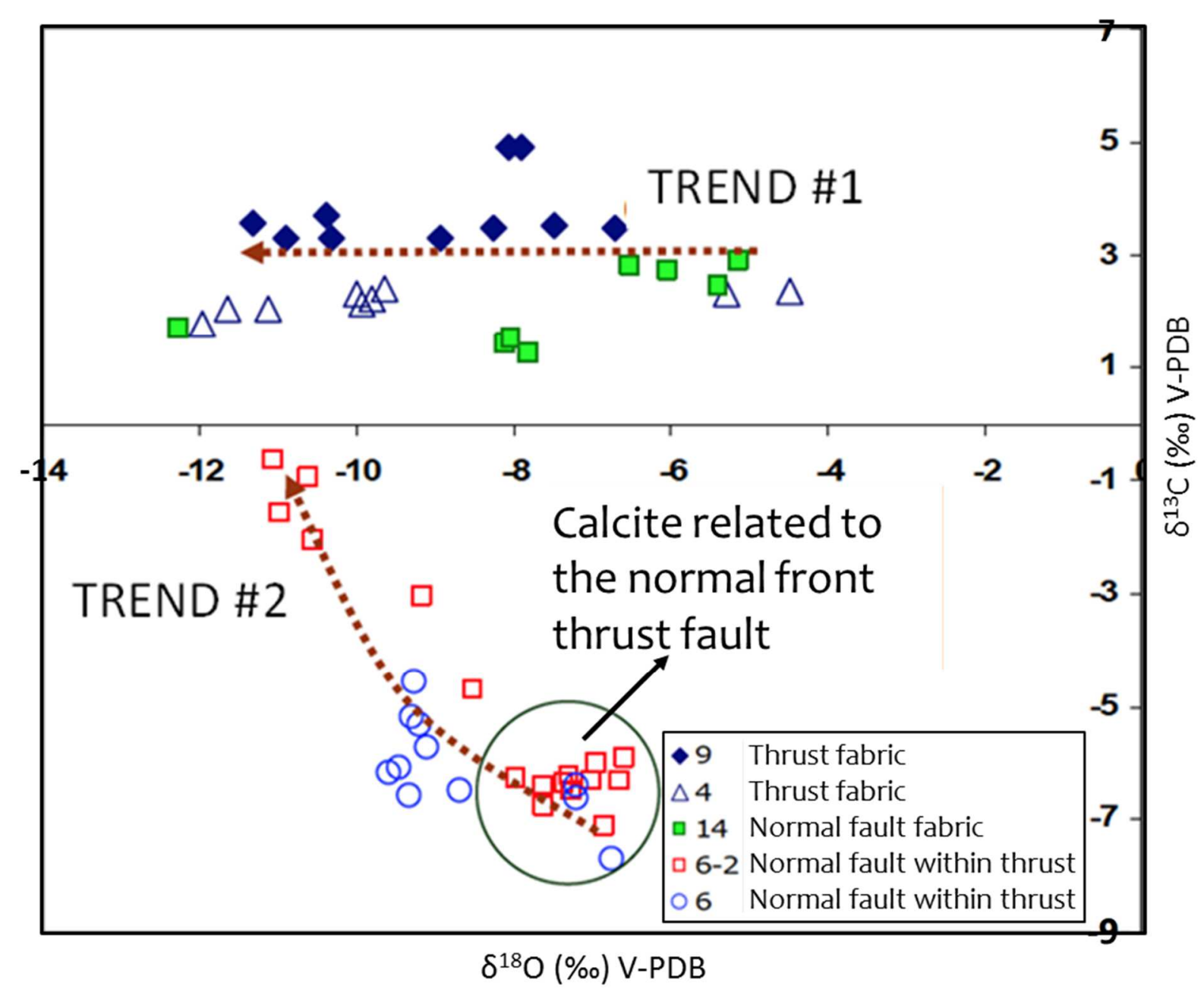

Figure 9. Isotope data for all samples from Labraña de Miguel (2004), illustrating the two main trends observed.

Stable isotope data of the thrust fabric samples $(9,4)$ exhibit $\delta^{18} \mathrm{O}$ values that decrease from older to younger calcite cements ( $\sim-4 \%$ to $-12 \%$, V-PDB) while $\delta^{13} \mathrm{C}$ values remain consistent ( 2\%o to 5\%, V-PDB) (Labraña de Miguel, 2004). The sample from the normal fault radiating from the crest of the Boixols anticline (14) also exhibited this same isotopic trend in both $\delta^{18} \mathrm{O}$ and $\delta^{13} \mathrm{C}$ values. Labraña de Miguel (2004) interpreted this trend of increasingly lighter $\delta^{18} \mathrm{O}$ values to be a progressive record of increasing temperature during cement precipitation, and therefore during burial (Figure 9, "Trend \#1"). The decrease in $\delta^{18} \mathrm{O}$ values 
was interpreted to potentially reflect a gradual increase in water-rock interactions or reflect a change in the initial fluids in which marine waters were gradually displaced by meteoric waters (Labraña de Miguel, 2004).

It is important to note that these differing interpretations for the observed trend in lighter $\delta^{18} \mathrm{O}$ values could support the differing interpretations of fracture formation and timing by Tavani et al. (2011) and Shackleton et al. (2011). The interpretation that the first trend was the result of a gradual increase in water-rock interactions due to burial could support Tavani et al. (2004)'s interpretation that the NNE-oriented J1/J3 fractures and normal faults were the result of a pre-folding extensional stage because deepening of the basin and increasing temperatures with burial would be expected in a rift setting; however, that interpretation could also support rapid burial due to an increased sediment load related to syn-tectonic sedimentation, which is also been observed in the Sant Corneli anticline (Nagtegaal et al., 1983; Simó et al., 1985; and Déramond et al., 1993). The other interpretation suggested by Labraña de Miguel (2004) for this trend was that an influx of meteoric waters could result in the same trend, which would support an uplift origin for the $\mathrm{J} 1$ fractures that is consistent with the interpretation that the $\mathrm{J} 1$ set is fold-related (Shackleton et al., 2011)

Although the two samples from the normal fault within the thrust fabric $(6,6-2)$ also exhibited a similar trend in $\delta^{18} \mathrm{O}$ values becoming increasingly lighter from older to younger cements ( -6\%o to $-11 \%$, V-PDB), these samples showed a very different trend with their $\delta^{13} \mathrm{C}$ values (Figure 9, “Trend \#2”, Labraña de Miguel, 2004). The $\delta^{13} \mathrm{C}$ values acquired from these remaining samples became heavier from older calcite cement to younger calcite cement $(\sim-8 \%$ o to $-1 \%$, V-PDB). Labraña de Miguel (2004) interpreted this trend in $\delta^{13} \mathrm{C}$ values to reflect a change in steady-state conditions recorded by multiple crack-seal events. Possible reasons given 
for this change in conditions included a gradual increase in temperature, $\delta^{18} \mathrm{O}$ dilution, an increase in water-rock interactions, and partial oxidation of divalent iron from the presence of pyrite which would cause $\mathrm{O}_{2}$ volatility to decrease and result in calcite precipitation that has heavier $\delta^{13} \mathrm{C}$ values and lighter $\delta^{18} \mathrm{O}$ values (Labraña de Miguel, 2004). Samples were sent out for ${ }^{87} \mathrm{Sr} /{ }^{86} \mathrm{Sr}$ isotope analyses to narrow down which process was recorded by the samples, but no results were published.

Little fluid inclusion data has been published regarding the fluid temperatures and pressures at the time of precipitation because fluid inclusions were rarely present within the samples. Labraña de Miguel (2004) was able to acquire a few homogenization temperatures of fluid inclusions present with in one of the samples from the normal fault within the thrust fabric (6-2). Within this sample, homogenization temperatures from primary unaltered fluid inclusions at the margin of the vein were $\sim 65^{\circ} \mathrm{C}$ and increased toward the center of the vein. Using this fluid inclusion homogenization data along with the $\delta^{18} \mathrm{O}$ values acquired for locations near each fluid inclusion location, Labraña de Miguel was able to determine an original fluid composition of $+2 \% \delta^{18} \mathrm{O}$. This suggested a parent fluid of altered marine origin that was then modified by increasing temperatures toward the center of the vein. Labraña de Miguel (2004) also stated that information currently available during her study suggested the normal fault zone near the Boixols thrust was influenced by hydrothermal fluids during early stages of thrusting, and this hydrothermal influence was recorded by the lowest values of $\delta^{13} \mathrm{C}$. The progressive trend of higher $\delta^{13} \mathrm{C}$ and lower $\delta^{18} \mathrm{O}$ values was suggested to reflect the changes in oxygen fugacity in thermal fluids trending toward basinal brines.

The research presented by Labraña de Miguel (2004) focused on thrust and normal fault fabrics, which are presumed to be associated with the $\mathrm{J} 1 / \mathrm{J} 3$ fracture sets of this study, and 
identified two distinct trends in the isotopic data of those fault fabrics (as discussed in the above paragraphs). Labraña de Miguel (2004) suggested two differing interpretations for the first trend (increasingly lighter $\delta^{18} \mathrm{O}$ values to be a progressive record of increasing temperature during cement precipitation, and therefore during burial) with no apparent preference for one over the other. The first interpretation suggested the trend was the result of a gradual increase in waterrock interactions, and the second interpretation suggested the trend was due to a change in the initial fluids in which marine waters were gradually displaced by meteoric waters. The second trend observed by Labraña de Miguel (2004) was that $\delta^{13} \mathrm{C}$ values from samples of the normal fault within the thrust became heavier from older calcite cement to younger calcite cement, which suggests that early thrusting recorded early hydrothermal fluids that were later influenced by the presence of basinal brines. This research only focuses on the $\mathrm{J} 1 / \mathrm{J} 3$ fracture sets and normal faults. However, it is important for future studies to also analyze the other fracture sets to gain an overall understanding of the evolution of the folding history of the Sant Corneli anticline.

\section{Methods}

Methods used in this study include field work, detailed thin section petrography, fluid inclusion studies, and stable isotope analyses.

\subsection{Field Work}

Field work was conducted in November 2014 at the Sant Corneli anticline. A total of 21 samples were collected at 14 sites in the field from multiple stratigraphic levels as well as various orientations. At each outcrop, the orientation of the joints/veins were measured and vein samples were collected. Figure 10 shows the locations sampled for this study. 


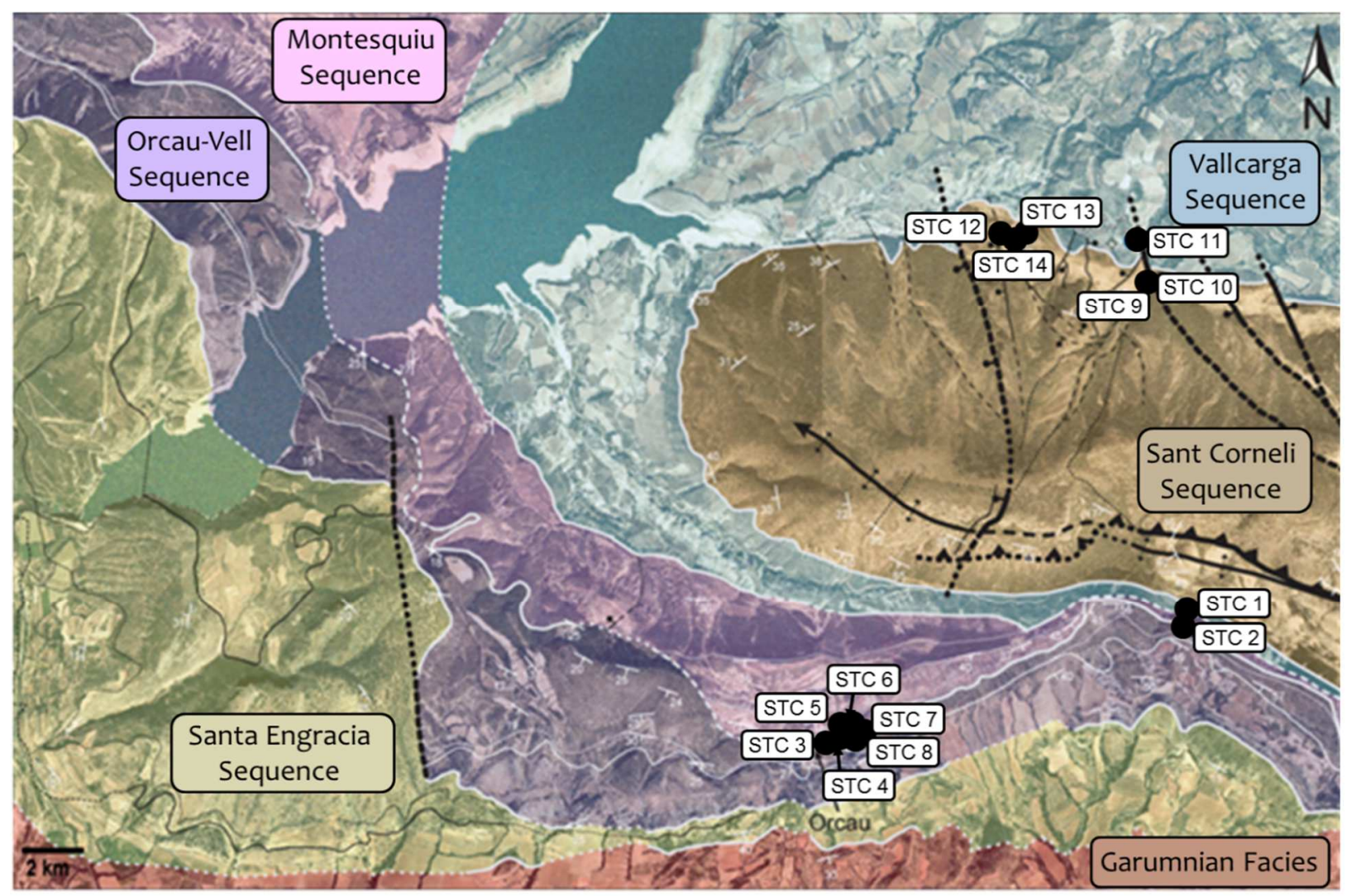

Figure 10. Geologic map of study area with an overlay of stratigraphic units (modified from Shackleton et al., 2013). Sample locations are marked by the yellow dots and labeled with their sample number.

\subsection{Petrography}

Thin-section petrography provides descriptions of the vein samples, yielding information regarding the number of stages and character of the veins. There are three main types of cements: overgrowth, gravitational, and isopachous. Overgrowth cements are cements in which the crystals overgrow grains of a rock but don't alter the grains. Gravitational cements are cements that typically form in pore spaces in the vadose zone, where gravity can play a role. Isopachous cements are the most common type of cement, and are cements that exhibit an approximately equal thickness lining an open space. This type of cement has several morphologies. Isopachous cements can be drusy in form, in which the cement is very finely crystalline, or radial fibrous, in which the crystals appear as fibers radiating out into pore space. Isopachous cements can also be 
blocky or elongate blocky, which commonly follows drusy cements. A blocky texture is typically where crystals are roughly equidimensional and randomly oriented, while elongate blocky crystals are moderately elongate, generally with a length/width ratio around 10 (Bons, 2000). Blocky and elongate blocky textures are characteristic textures of syntaxial veins, in which the vein cements grow from the wall rock in toward the center of the vein (Bons, 2000; Bons et al., 2012). Fibrous textures have also been observed and described in the literature, where the crystals have a much higher length/width ratio than in elongate blocky textures and the crystal boundaries are smooth (Bons, 2000; Bons et al., 2012). Fibrous cement textures are typically seen in antitaxial veins, meaning that the crystals appear to be in optical continuity across the vein and also appear to grow from a median suture line toward the walls of the vein (Bons, 2000; Bons et al., 2012).

Descriptions of cements includes the mineralogy, type and morphology of cement, and the paragenetic sequence (or order of formation) of cement generations. Each different morphology of isopachous cement and/or change in mineralogy indicates a different generation of cement. Syntaxial tectonic vein cements grow from a pre-existing surface, such as the walls of a fracture, indicating the cement adjacent to the host rock the first generation of cement (Bons, 2000; Bons et al., 2012). Each change in mineralogy and/or morphology following the first generation of cement represents a new generation of cement. Vein cements are not impervious to diagenetic alteration, such as dissolution and later precipitation of new cements, making detailed observations of cements crucial to interpretations.

At least one small-format thick-section $(50-150 \mu \mathrm{m})$ for each of the 21 samples has been prepared for petrography and fluid inclusion analyses using Central Connecticut State University's rock preparation lab. Following the thick-section preparation method of Holland et 
al. (1978), and also outlined by Goldstein \& Reynolds (1994), a total of 32 doubly-polished thick-sections were prepared from the samples collected. No stains were applied to the thin sections. Samples were prioritized for analyses by choosing one representative sample of each joint set based on vein orientations.

\subsection{Fluid Inclusion Petrography}

Petrography is crucial when conducting fluid inclusion studies. Petrographic observations of fluid inclusion assemblages (FIAs) are used to determine the timing of fluid inclusions that have been trapped in cements. Fluid inclusions are characterized by their origin as primary, pseudosecondary, secondary or undifferentiated. Primary inclusions form when the parent fluids that precipitate cements are trapped in imperfections on a surface of the crystal or on growth planes due to rapid crystal growth. These primary inclusions therefore contain a sample of the fluid responsible for precipitation of the cement (Goldstein \& Reynolds, 1994).

Primary inclusions are best identified by their relationship to a crystal's growth zonation. Primary inclusions in calcite are found in growth zones defined by a single sheet of inclusions, a cloudy crystal, or confined by growth-zone boundaries (some examples are shown in Fig. 11). Primary inclusions found in calcite can also have almost any shape, ranging from globular to negative crystal shape to irregular (Goldstein \& Reynolds, 1994). 


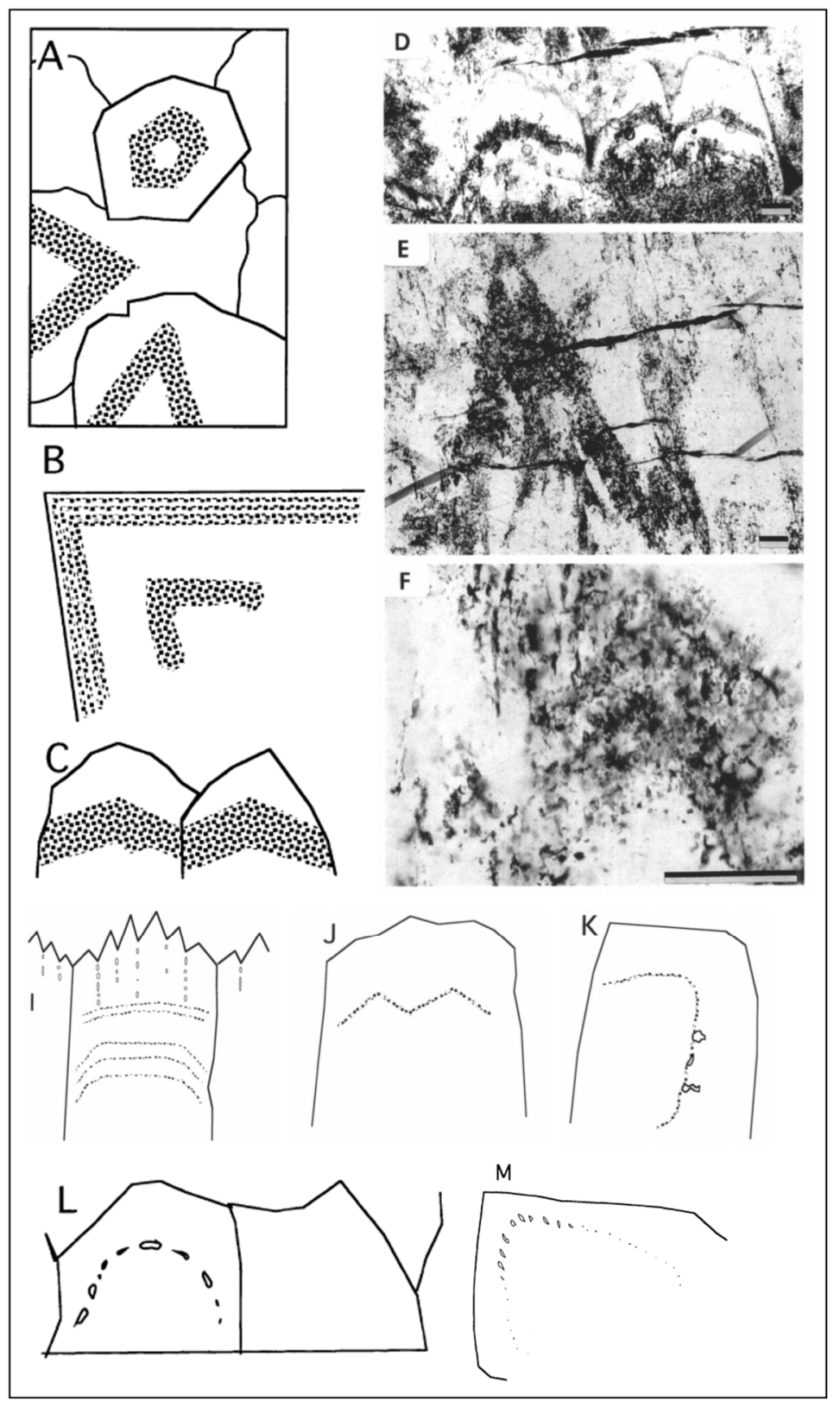

Figure 11. Examples of primary fluid inclusions in calcite (modified from Goldstein \& Reynolds, 1994).

Secondary and pseudosecondary inclusions form after initial mineral precipitation, when microfractures, shear planes or deformation twin planes can form due to deformation. As these microstructures heal, later fluids become trapped as fluid inclusions that record the fluids present after mineral growth (Goldstein \& Reynolds, 1994). Secondary inclusions are trapped after 
crystal growth is complete, and may appear to cut across any or all growth zones of a crystal. Pseudosecondary inclusions, however, are trapped before crystal growth is complete, and terminate against a growth-zone boundary (Goldstein \& Reynolds, 1994). Undifferentiated inclusions are isolated inclusions whose formation is unknown.

It is important to understand whether observed fluid inclusions are primary or secondary/pseudosecondary/undifferentiated because only primary inclusions represent the parent fluids that the cements formed from (Goldstein \& Reynolds, 1994). Secondary and pseudosecondary inclusions generally represent stages of fluids that have passed through the vein during later fracture events, and do not represent the conditions of initial fracturing. It is also important to describe the fluid phases present within the inclusions. For example, fluids trapped as inclusions may be single-phase liquid, single-phase vapor, or two-phase liquid-vapor inclusions (Goldstein \& Reynolds, 1994).

Thin sections are scanned for useable inclusions within each sample. The inclusions are described as primary, secondary/pseudosecondary, or undifferentiated, and then mapped as fluid inclusion assemblages (Goldstein \& Reynolds, 1994) similar to the manner described by Touret (2001). Once a primary fluid inclusion assemblage is identified, the inclusions within the assemblage are described. The description of individual inclusions includes noting the shapes of the inclusions and the phases present within the inclusions. It is important to note if the inclusions within an assemblage all have the same phase(s) present within, and whether they have consistent liquid-vapor ratios if they are two-phase liquid-vapor inclusions. If the inclusions within an assemblage are not consistent with the phases present, then it is possible that some of the inclusions may have been stretched or altered. An assemblage that contains all two-phase 
liquid-vapor inclusions and that do not exhibit consistent liquid-vapor ratios is another indication that some of the inclusions may have been altered.

\subsection{Fluid Inclusion Microthermometry}

Fluid inclusion microthermometry refers to the changing of the temperature of fluid inclusions and observing any phase changes that occur at specific temperatures. Fluid inclusion microthermometry can be used to determine the temperature of fluid at entrapment, fluid salinity, major ion composition, fluid density, and pressure-temperature (P-T) history (Goldstein \& Reynolds, 1994). The two fluid inclusion microthermometric methods used in this study are homogenization and freezing/melting analyses. Homogenization studies involve the heating of two-phase liquid-vapor inclusions until the temperature at which the vapor bubble homogenizes with the liquid. This temperature at which the two phases homogenize into one is called the homogenization temperature $\left(\mathrm{T}_{\mathrm{h}}\right)$, and it represents the minimum parent fluid temperature at the time of entrapment.

Homogenization studies involve a process of cycling, in which the inclusions are heated slowly until the vapor bubble disappears and then cooled very slowly several times to determine a homogenization temperature. As the inclusion starts to cool during each cycle, the vapor bubble will either suddenly reappear, or will gradually return. A sudden reappearance of the vapor bubble indicates a temperature slightly higher than the homogenization temperature was recorded for the cycle. If the vapor bubble gradually returns, the temperature recorded when the vapor bubble disappeared is slightly lower than the homogenization temperature. These cycles are repeated several times, heating the observed inclusions as slowly as $0.1{ }^{\circ} \mathrm{C}$ increments to narrow down the range for the homogenization temperature with as narrow of a degree of 
uncertainty as possible. This entire process is then repeated at least two more times to make sure the results are reproducible, and to what margin of error they are reproducible within. This repetition helps to ensure that the homogenization temperatures are reported as accurately as possible as well as to make sure the inclusions were not altered in any way during the first or second cycling runs.

It is important to note that homogenization runs must be completed on a sample before freezing-melting runs are conducted. Once freezing-melting begins with a sample, it is no longer viable for homogenization runs because freezing the inclusions may cause the inclusions to stretch (Goldstein \& Reynolds, 1994). If the inclusions stretch, they no longer accurately reflect the original trapping temperature because the pressure at which those fluids were trapped has been changed.

Freezing-melting microthermometry involves cooling an inclusion until it freezes and identifying specific phases (ie. solid - ice, halite, etc.; vapor; liquid) and the temperatures at which they exist as the inclusion slowly warms back up to determine the salinity and major ion composition of the fluid. Indicators of inclusions being frozen include a glassy look, a deformed vapor bubble (if the inclusion is two-phase liquid-vapor), and/or the inclusion becoming very dark or turning black. The inclusions must be warmed very slowly and examined for any changes in color or texture, while noting the temperature at which those changes occur. An "orange peel" texture will typically form as the frozen inclusions slowly warm, and the appearance of this texture represents the eutectic temperature $\left(\mathrm{T}_{\mathrm{eu}}\right)$ : the temperature at which melting begins and the first liquid appears. The eutectic temperature can provide clues regarding the major ions present in solution. As the inclusions continue to warm, they will reach a temperature at which the last bit of solid melts. This temperature is called the final melting temperature $\left(\mathrm{T}_{\mathrm{m}}\right)$, which can be 
used to estimate the fluid salinity. It is important to determine what the solid(s) are that form when the inclusions freeze and warm back up (such as ice, hydrohalite, etc.), and record the $\mathrm{T}_{\mathrm{m}}$ for each solid to accurately estimate the salinity of the fluid. Conducting homogenization and freezing-melting runs on inclusions smaller than $\sim 20 \mu \mathrm{m}$ in size is very difficult, because phase changes that occur in fluid inclusions of that size cannot be observed. This is a challenge especially when working with fluid inclusions in calcite, as they tend to be extremely small and are even more difficult to see due to the double refraction property of calcite.

Conventional heating and freezing microthermometric analyses were conducted using a modified gas-flow U.S. Geological Survey-type-heating freezing stage manufactured by FLUID Inc. The modified U.S.G.S. stage was calibrated at $0^{\circ} \mathrm{C}$ (ice bath), $374^{\circ} \mathrm{C}$ (critical point of water), and $-56.6^{\circ} \mathrm{C}\left(\mathrm{CO}_{2}\right.$ triple point) (the latter two standards provided by SYNFLINC, Inc.). These analyses were conducted on the prepared thin sections of each sample that were also used for petrography.

\section{$\underline{3.5 \text { Stable Isotope Analysis }}$}

Samples of vein calcite and host rock were analyzed for carbon and oxygen stable isotopes. Each hand sample of vein and associated host rock were incrementally sampled along a traverse from the vein to the host rock using a dental drill and powdered with a mortar and pestle. If multiple stages of calcite were observed, each stage was sampled if possible. In cases where it was not possible to separate the generations of vein cement, the sample was run as a bulk sample. Prepped samples were analyzed at the Sharma Isotope Lab at West Virginia University using Finnigan Gas Bench II Deviceonline with a Thermo Delta V Advantage gas isotope ratio mass spectrometer. $\delta^{18} \mathrm{O}$ and $\delta^{13} \mathrm{C}$ values are reported with respect to the VPDB 
(Vienna Peedee Belemnite) standard in per mil (\%o). Results for oxygen and carbon are generally reproducible within $0.02 \%$.

Secondary calcite occurs as fracture fillings in marine limestones and carbonates, and its isotopic composition tends to be depleted from that of marine limestones (Clark \& Fritz, 1997). Carbon isotope signatures of calcite can provide insight into the source of the carbon and also if the subsurface fluid reservoirs were open or closed systems. For example, if the $\delta^{13} \mathrm{C}$ values of the calcite differ from that of the presently existing host rock, the source of the carbon is unlikely to be the host rock, and would therefore indicate an open subsurface fluid network (Dietrich et al., 1983; Gao et al., 1992). However, if the carbon isotope values acquired for the calcite veins are quite similar to those of the adjacent host rock, it is likely that the source of the carbon is locally derived due to isotopic exchange with the host rocks, potentially from buffering by pressure solution (Dietrich et al., 1983; Evans et al., 2012). Similar carbon isotope values between calcite veins and the surrounding host rock would also therefore represent a closed system with respect to subsurface fluids (Dietrich et al., 1983).

Oxygen isotope signatures of calcite can provide information regarding the origin of the fluids due to natural variations in isotope fractionation. Oxygen isotope fractionation is influenced by temperature (O’Neil et al., 1969; Friedman \& O’Neil, 1977), in which preferential incorporation of ${ }^{18} \mathrm{O}$ is greater at lower temperatures and reduced at higher temperatures (Clark \& Fitz, 1997; Railsback, 2006). Therefore, regardless of the temperature at which calcite precipitates from a fluid, the calcite will be enriched in ${ }^{18} \mathrm{O}$ (meaning the $\delta^{18} \mathrm{O}$ of the calcite will have a more positive value) in comparison to the precipitating fluid (Railsback, 2006). If the temperatures of the parent fluids are known, such as from fluid inclusion homogenization temperatures, the isotope composition of the parent fluids can be determined using the 
fractionation equation from O’Neil et al. (1969) (O’Neil et al., 1969; Friedman \& O’Neil, 1977; Labraña de Miguel, 2004; Lefticariu et al., 2005). Because different types of fluids have distinct oxygen isotope signatures, the calculated oxygen isotope values of the parent fluids would then indicate if the parent fluids were of marine, meteoric, hydrothermal or a basinal brine origin. For example, modern open ocean waters typically have $\delta^{18} \mathrm{O}$ value very close to $0 \%$ with respect to VSMOW (Vienna Standard Mean Ocean Water standard, reported in per mil). In general, fresh water ranges from $\sim-45-+10 \%$ o $\delta^{18} \mathrm{O}$ vs. VSMOW, with low-altitude meteoric waters typically around $-4 \%$ and high-latitude meteoric waters around -10\%o (Railsback, 2006). Examples of the temperature-dependent relationships between parent waters and calcite are shown in Figure 12.

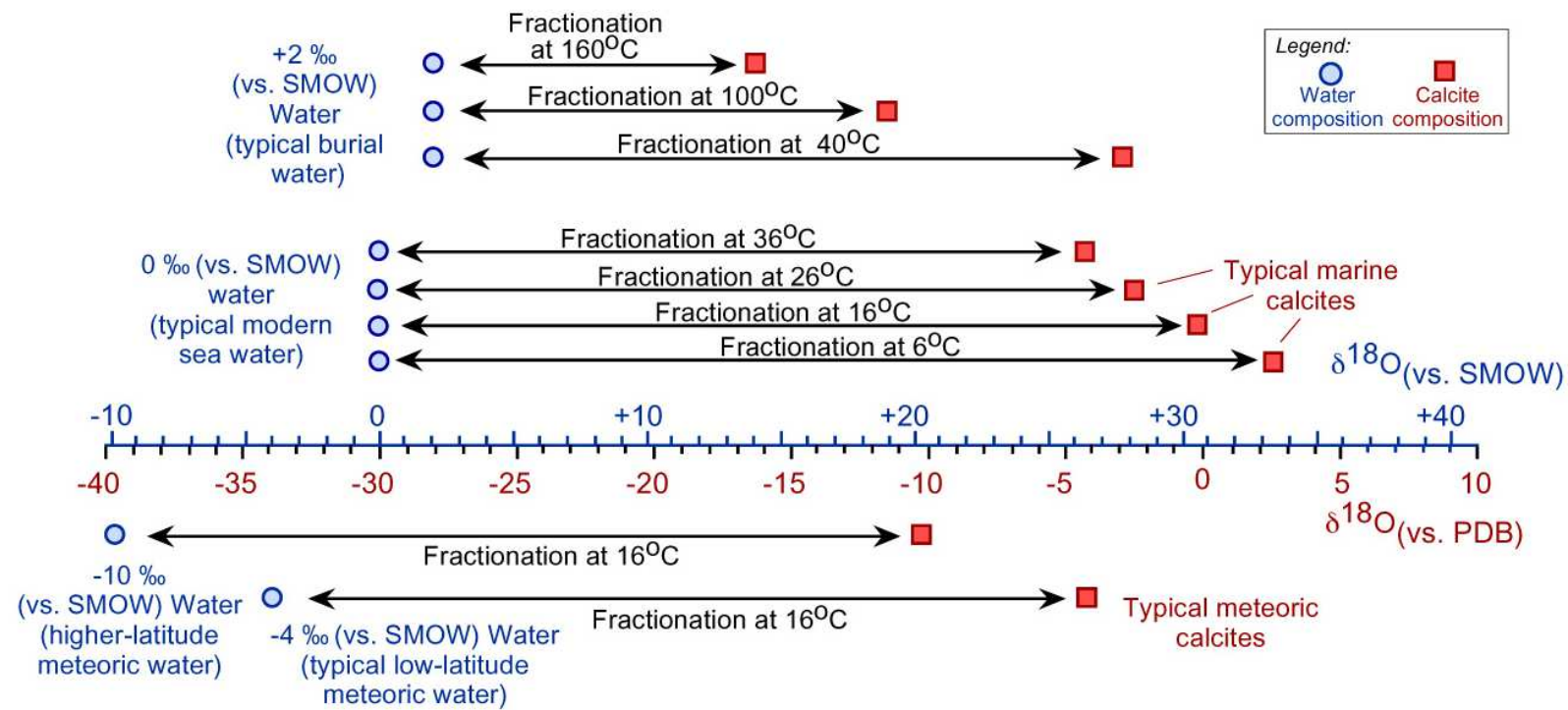

Figure 12. A generalized graphic image of fractionation of oxygen isotopes between water and calcite (from Railsback, 2006). 


\section{Observations \& Results}

\subsection{J1/J3 Set:}

\section{Thin Section Petrography}

Samples STC 12A (Fig. 13, 15, 17) and STC 12B (Fig. 14, 16, 18) were sampled from the $\mathrm{J} 1 / \mathrm{J} 3$ sets in the Sant Corneli sequence on the backlimb of the anticline (see Fig. 10 for location). The $\mathrm{J} 1$ and $\mathrm{J} 3$ sets have been grouped together due to lack of cross-cutting relationships with the $\mathrm{J} 2$ set to indicate whether they are specifically of the $\mathrm{J} 1$ or $\mathrm{J} 3$ set; however, the vein sampled for STC 12B was observed at the outcrop to cross-cut the vein sampled for STC 12A, indicating STC 12A is at least older than STC 12B. The paragenetic sequences described below for each sample are summarized in Tables 2 and 3, and are also shown schematically in Figures 17 and 18. Sample STC 12A is characterized by two distinct generations of cement. The first generation of cement (adjacent to the host rock) is a curved elongate blocky calcite that is a cloudy, milky white color. A second generation of clear, small blocky calcite follows the first generation of calcite. STC 12B is characterized by a generation of small blocky calcite adjacent to the host rock, followed by a younger generation of large blocky calcite. Both generations of calcite cement seen in sample STC 12B are clear. Both samples exhibit a later generation of small blocky quartz that appears to fill in small pockets in which the older calcite underwent dissolution (see Fig. 15, 16). There are also no iron oxides present in either sample. 


\begin{tabular}{|l|c|}
\hline STC 12A (J1/J3, Sant Corneli Sequence) & \multicolumn{2}{|c|}{ Generation of Cement } \\
\hline CEMENT TYPE & EARLY \\
\hline Drusy Calcite & \\
\hline Small Blocky Calcite & \multicolumn{2}{||}{} \\
\hline Elongate Blocky Calcite & \multicolumn{2}{|}{} \\
\hline Small Blocky Quartz & \multicolumn{2}{|}{} \\
\hline
\end{tabular}

Table 2. Paragenetic sequence of cement precipitation for sample STC 12A.

\begin{tabular}{|l|c|}
\hline STC 12B (J1/J3, Sant Corneli Sequence) & \multicolumn{2}{|c|}{ Generation of Cement } \\
\hline CEMENT TYPE & EARLY \\
\hline Drusy Calcite & \\
\hline Small Blocky Calcite & \\
\hline Large Blocky Calcite & \\
\hline Small Blocky Quartz & \\
\hline
\end{tabular}

Table 3. Paragenetic sequence of cement precipitation for sample STC 12B. 


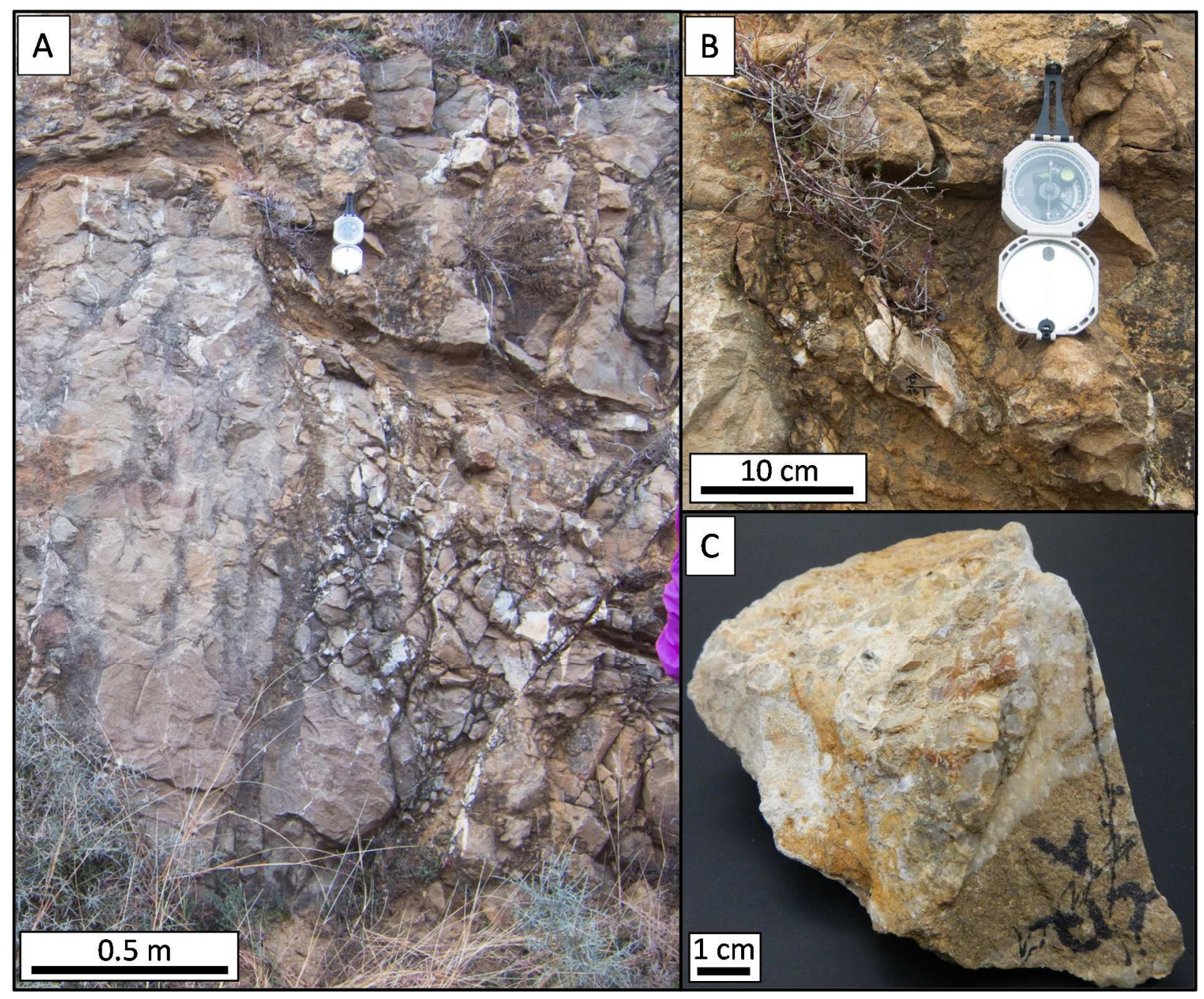

Figure 13. Images of STC 12A in outcrop and hand sample. Boxes A and B show a view of the outcrop sampled and an up-close view of the vein in outcrop. Box $\mathrm{C}$ shows a hand sample of STC 12A sampled from the outcrop. 


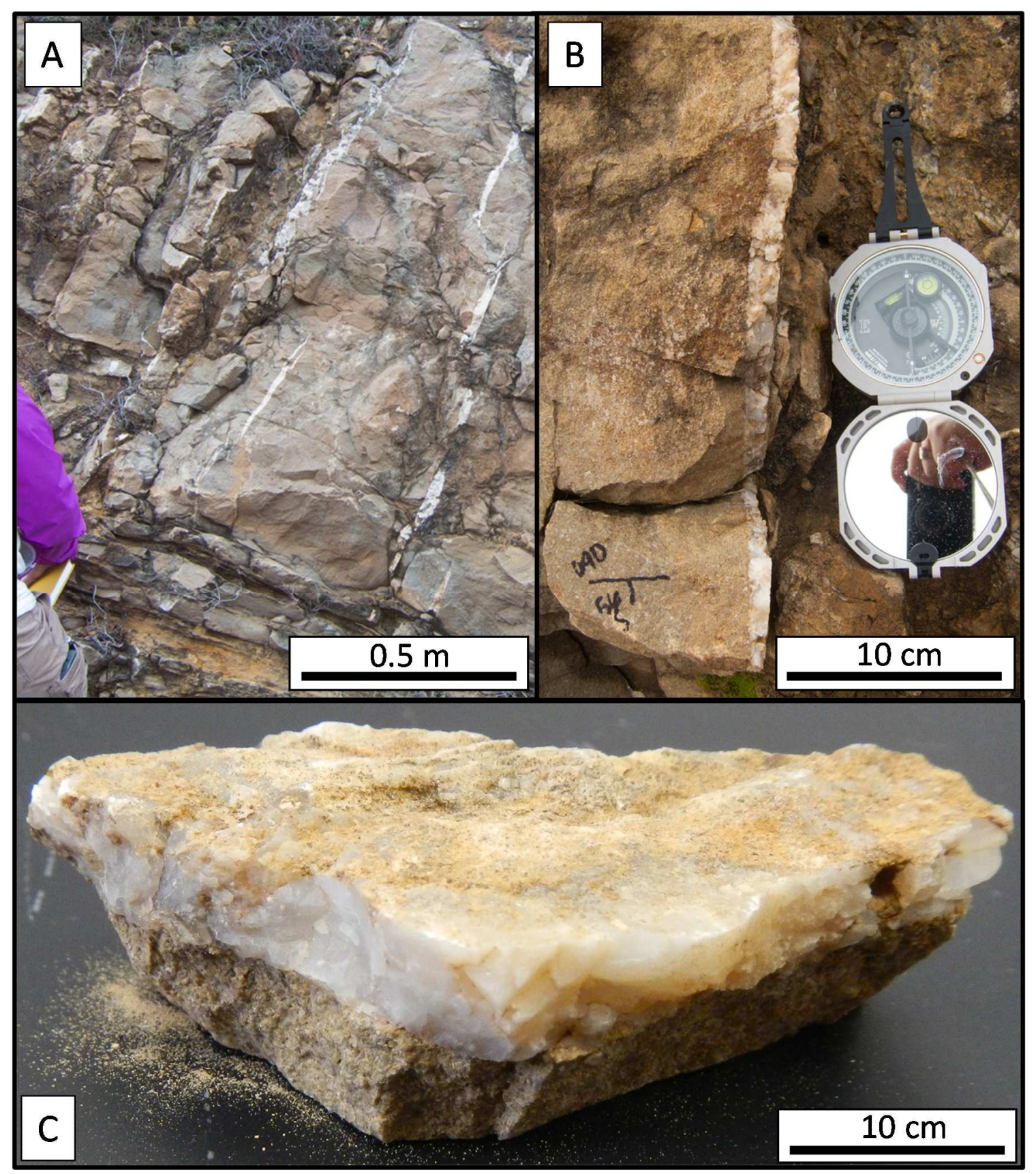

Figure 14. Images of STC 12B in outcrop and hand sample. Boxes A and B show a view of the outcrop sampled and an up-close view of the vein in outcrop. Box $\mathrm{C}$ shows a hand sample of STC 12B sampled from the outcrop. 


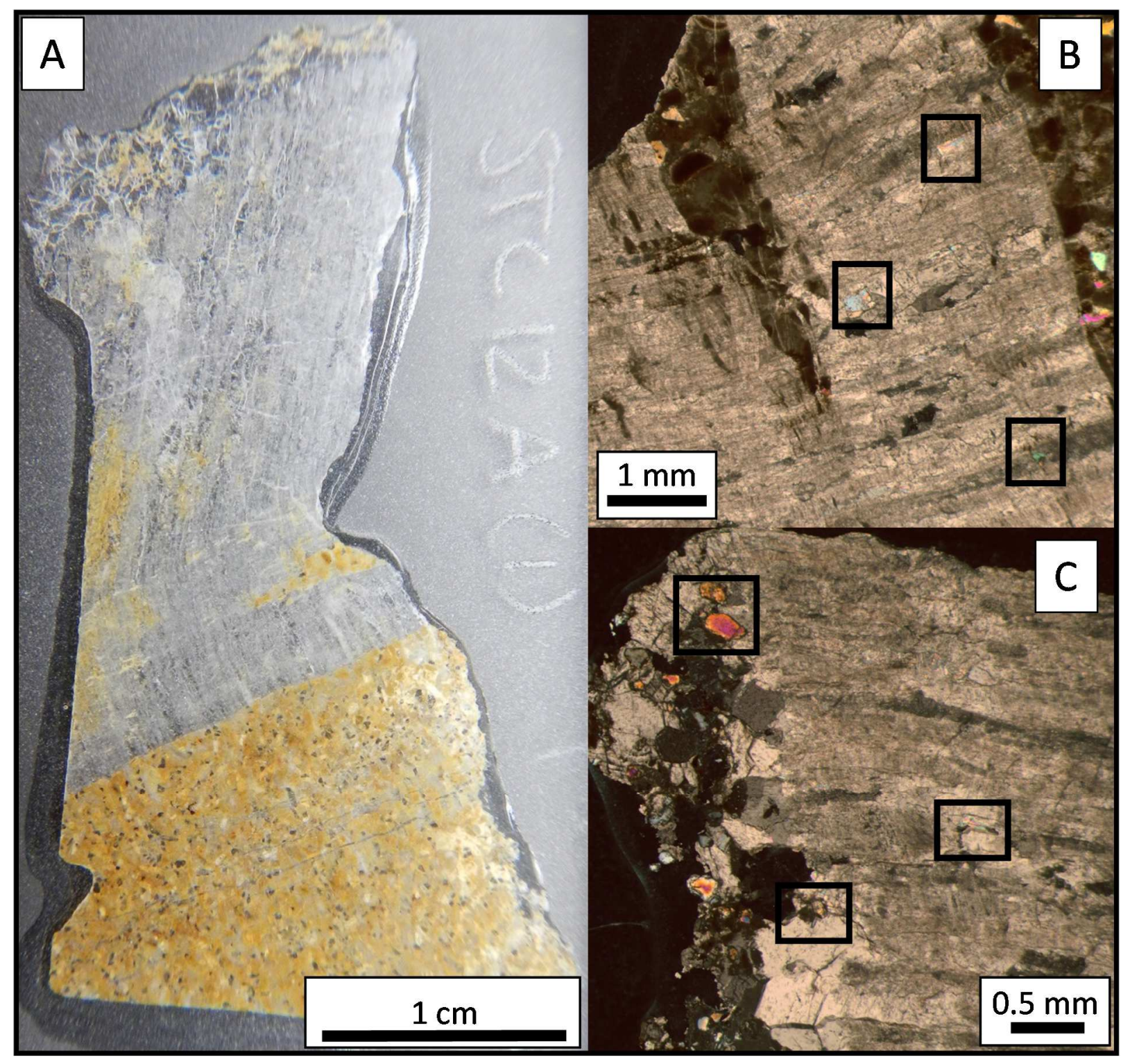

Figure 15. The full thin-section of sample STC 12A in plain light is shown in Box A. Box B shows a close-up of the elongate blocky calcite cement in cross-polarized light, with late quartz highlighted by the small black boxes. Box $\mathrm{C}$ shows a close-up of the small blocky calcite cement in cross-polarized light, with late quartz highlighted by small black boxes. 


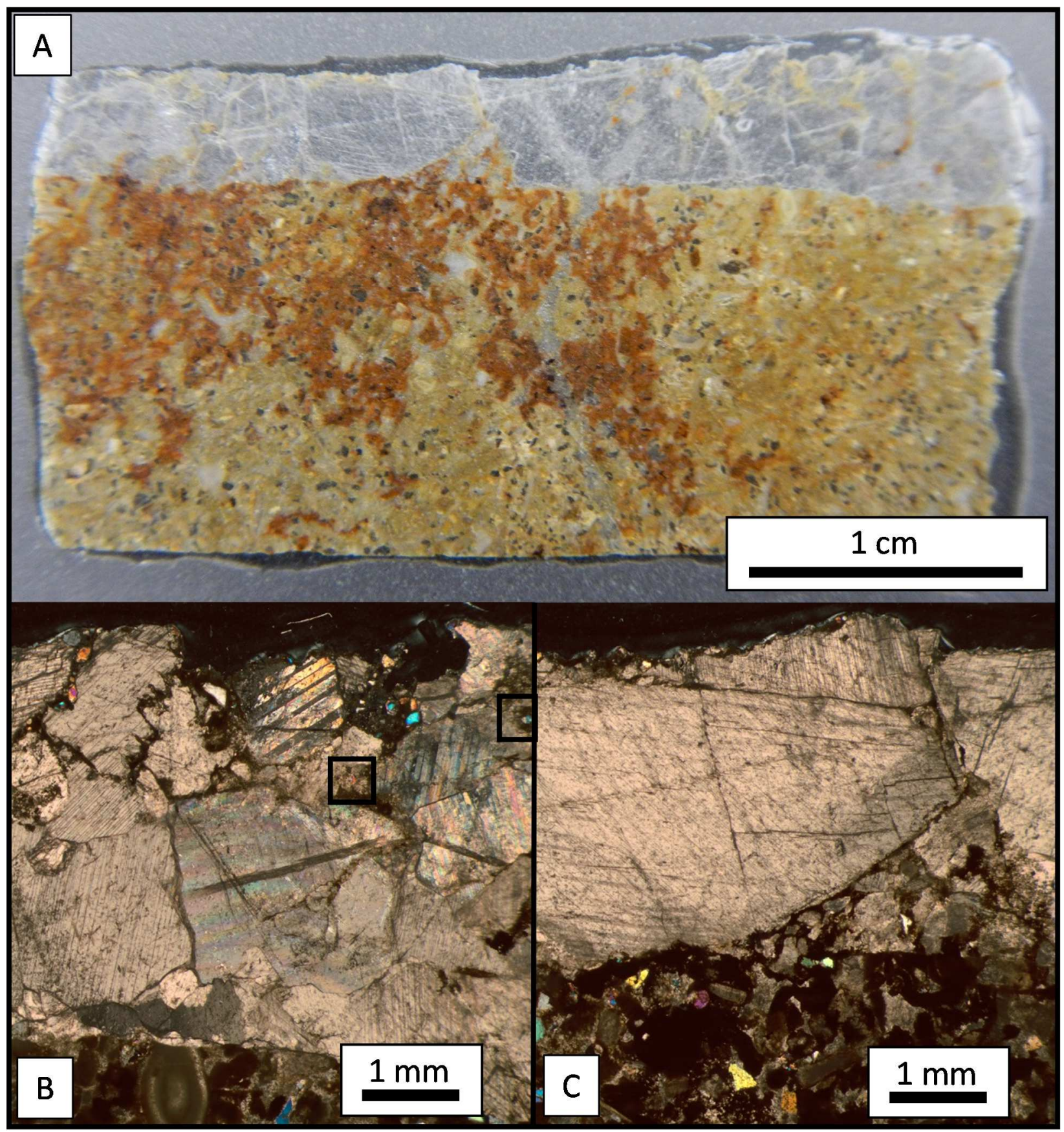

Figure 16. The full thin-section of sample STC 12B in plain light is shown in Box A. Box B shows a close-up of the small and large blocky calcite cement in cross-polarized light, with late quartz highlighted by the small black boxes. Box $\mathrm{C}$ shows a close-up of the large blocky calcite cement in cross-polarized light. 


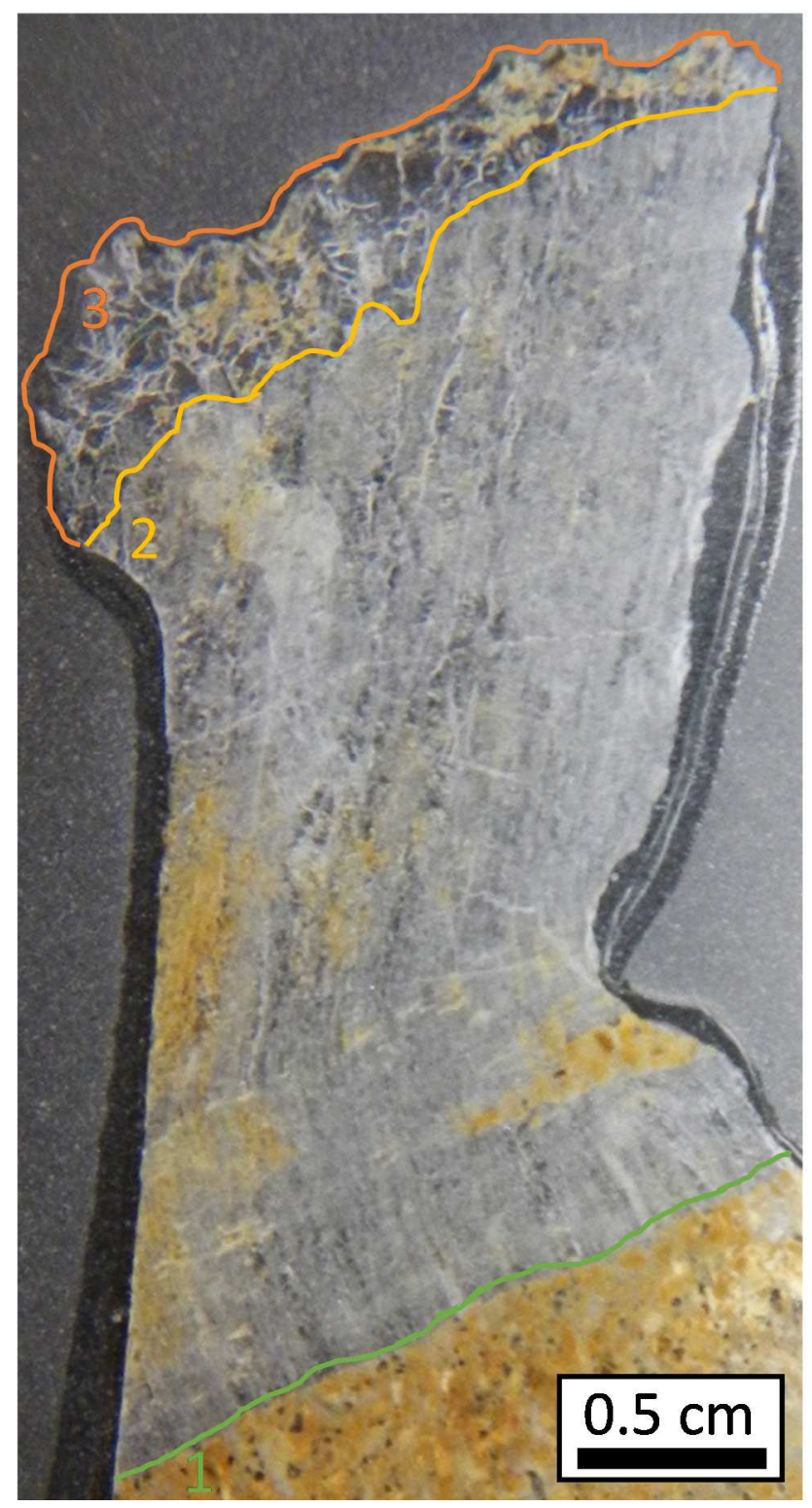

\section{3- Small blocky calcite \\ 2 - Elongate blocky calcite \\ 1 - Drusy calcite}

Figure 17. Schematic diagram highlighting the different stages of vein cements. The green boundary outlines the top of the drusy calcite, the yellow boundary outlines the top of the elongate blocky calcite, and the top of the small blocky calcite is bounded by the orange boundary. The late quartz is not highlighted in this schematic, but can be seen in Figure 14 above. 


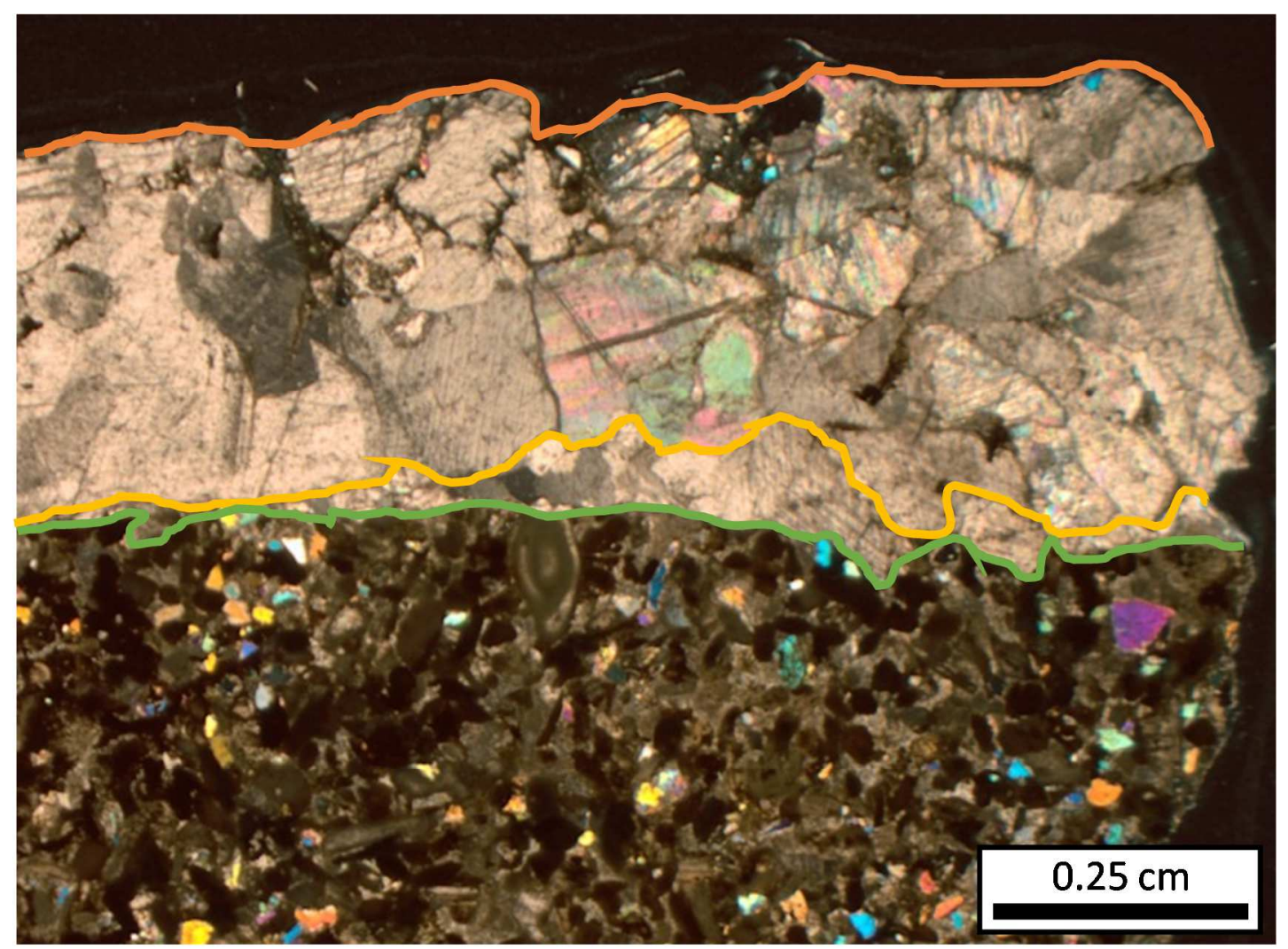

\section{3 - Large blocky calcite \\ 2 - Small blocky calcite \\ 1 - Drusy calcite}

Figure 18. Schematic image of STC 12B cements. The first generation of cement, drusy calcite, is highlighted in green. The yellow boundary represents the top of the small blocky calcite cement, and the orange boundary represents the top of the large blocky calcite cement. The late quartz cement is not highlighted in this schematic, but is shown in Figure 15.

\section{Fluid Inclusion Petrography}

A distinct primary fluid inclusion assemblage was observed in STC 12B (Fig. 19). This assemblage mimicked part of a growth band in the calcite crystal. The inclusions were all cubic to elongate cubic in shape with rounded corners, and there was no evidence indicating the inclusions had been stretched. Both liquid and vapor phases were observed at consistent ratios in the primary inclusions. This primary assemblage was cut by a thin, curvy band of 
secondary/pseudosecondary inclusions (highlighted by Box B in Fig. 19). An isolated undifferentiated fluid inclusion was also observed in the vicinity of the primary inclusion assemblage (shown in Box C in Fig. 19). The shape and liquid to vapor ratio of the undifferentiated inclusion was inconsistent with the other observed inclusion assemblages. The fluid inclusions were observed under both plain light and ultraviolet light. However, there was no fluorescence observed within the inclusions when they were under UV light (Fig. 20).

A distinct primary fluid inclusion assemblage was also observed within the elongate blocky calcite in STC 12A (Fig. 21). This assemblage formed a crystal growth zone. These inclusions appeared to all be consistent in size, although they were too small ( $<1$ to $5 \mu \mathrm{m}$ in size) to distinguish their shapes. It was also difficult to distinguish the phases present within these inclusions due to their small size. Secondary/pseudosecondary fluid inclusions were also observed in association with the primary fluid inclusion assemblage. There are several trails of these secondary/pseudosecondary inclusion assemblages cutting across the primary inclusion assemblage as well as smaller, curved trails that appear outside the primary fluid inclusion assemblage. 


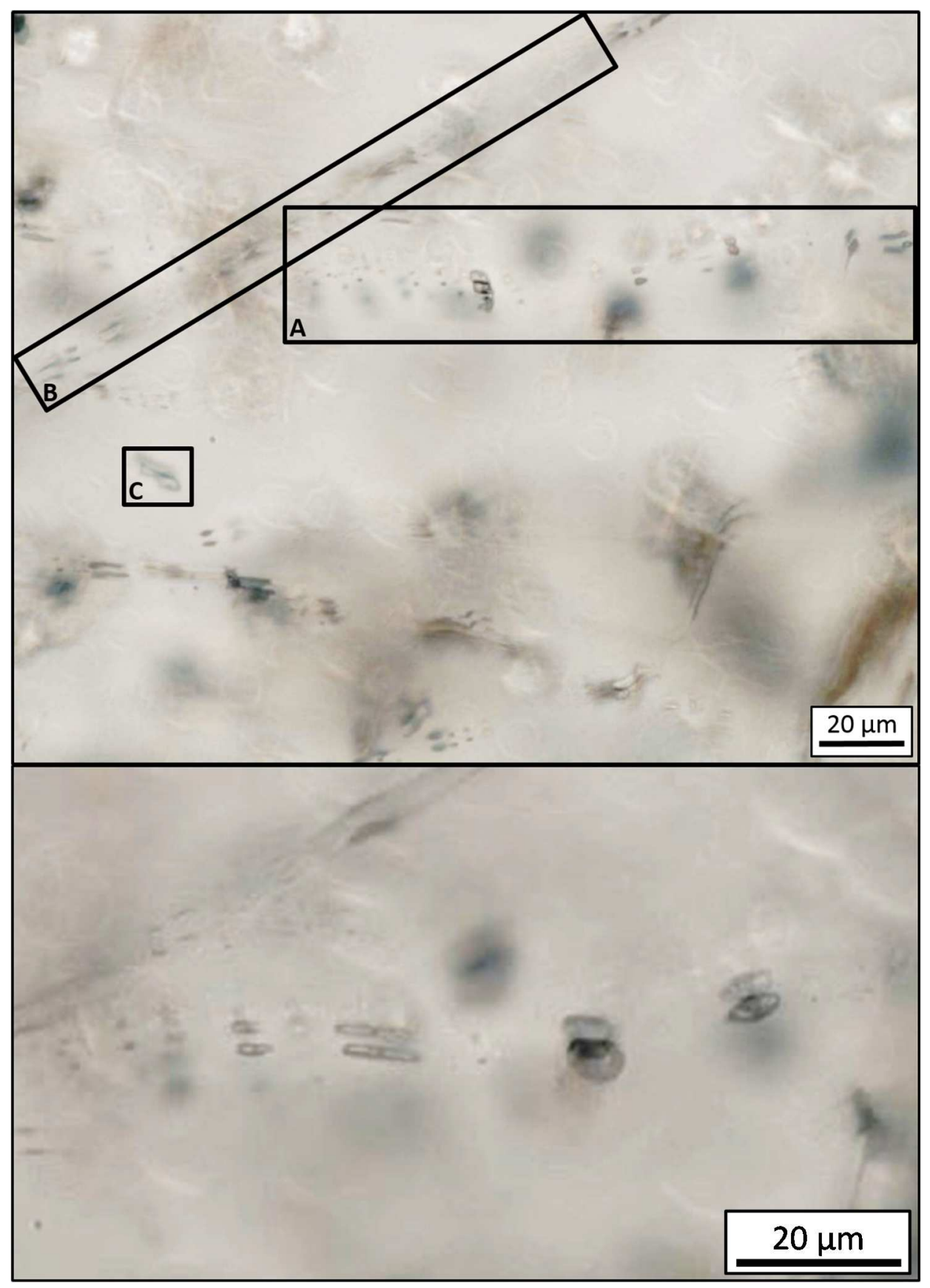

Figure 19. Fluid inclusions observed within sample STC 12B, shown here in plain light. The top image shows the FIAs in relation to each other. Box A highlights a primary fluid inclusion assemblage. Box B is showing an assemblage of secondary/pseudosecondary inclusions that cut the primary assemblage. An undifferentiated inclusion is highlighted by Box C. The bottom image shows an enlarged image of the primary fluid inclusion assemblage with different inclusions in focus. 


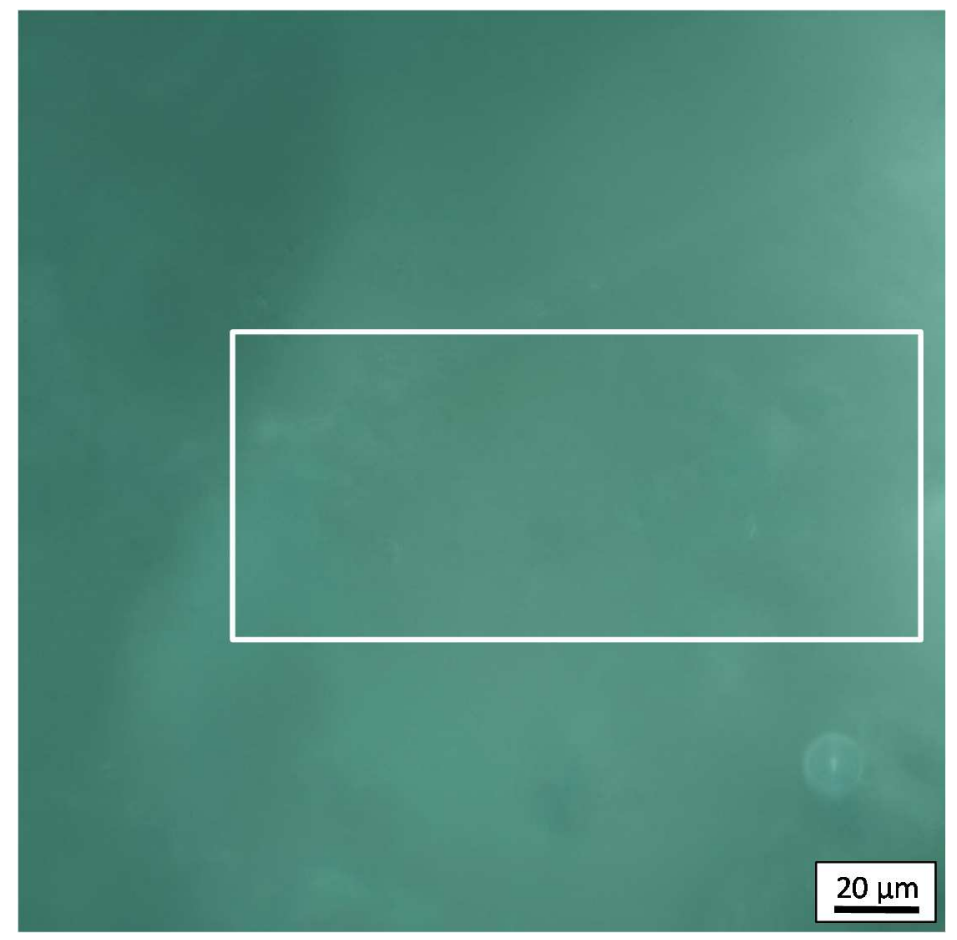

Figure 20. Image of the primary fluid inclusion assemblage (highlighted by the white box) observed in sample STC 12B under UV light.

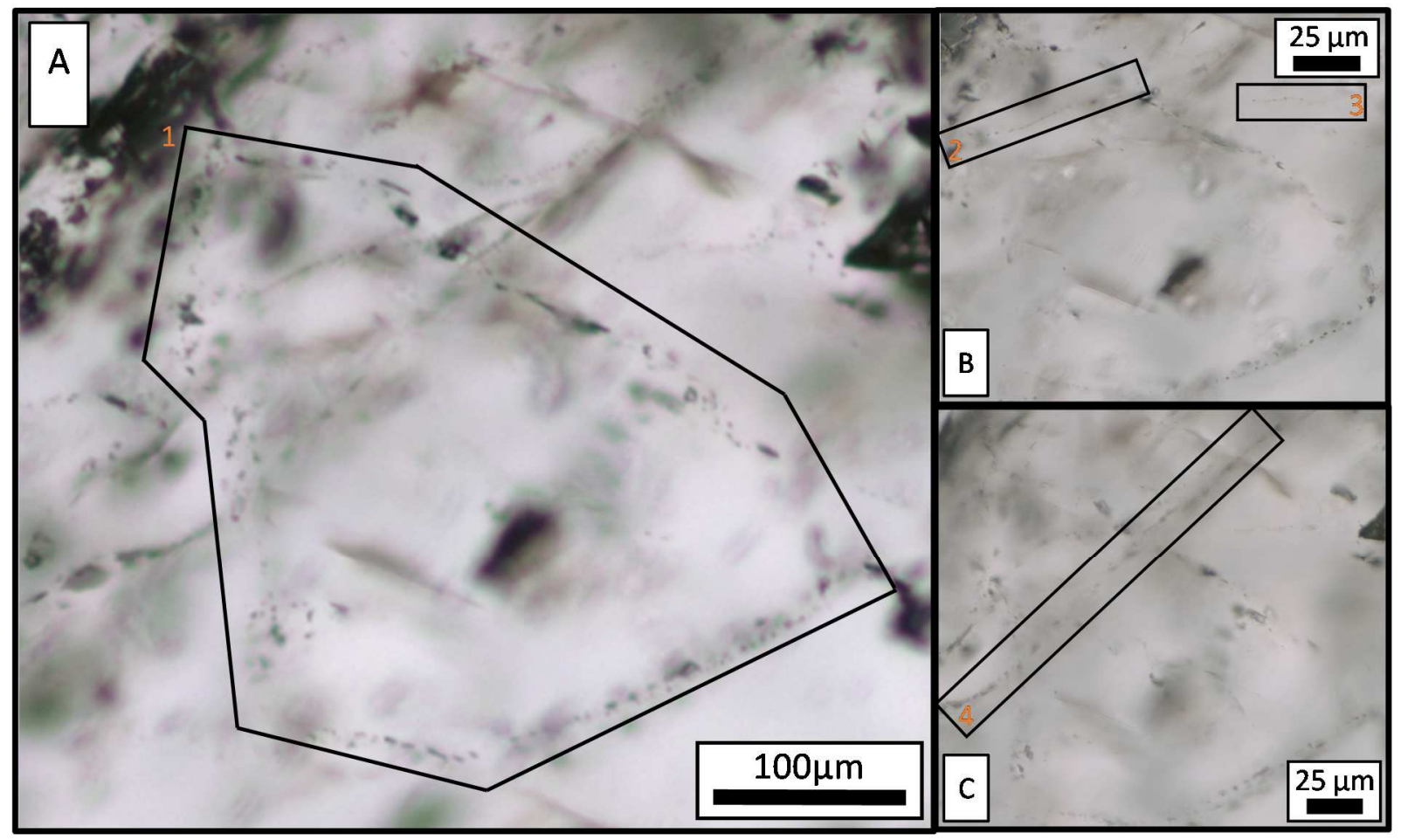

Figure 21. Image showing a primary FIA (1) within the elongate blocky calcite of STC 12A (Box A). Although the individual inclusions are extremely small, they exhibit a clear growth zone within the crystal. Boxes $\mathrm{B}$ and $\mathrm{C}$ highlight secondary/pseudosecondary inclusion assemblages $(2,3,4)$ in relation to the primary inclusion assemblage. 
Fluid inclusions were also observed within several of the quartz crystals that represent later fluids (Fig. 22). The late quartz crystals contained abundant fluid inclusions that exhibited both liquid and vapor phases. However, it was extremely difficult to discern primary inclusions from secondary/pseudosecondary and undifferentiated inclusions because the inclusions do not form any distinct patterns with respect to crystal growth and also appear to all cross-cut each other. These inclusions varied in size, ranging from $\sim 1 \mu$ to $\sim 10 \mu \mathrm{m}$. Many of these inclusions exhibited consistent liquid to vapor ratios, although there were several inclusions that did not exhibit consistent L-V ratios. The fluid inclusions observed in the late quartz also did not fluoresce under UV light.

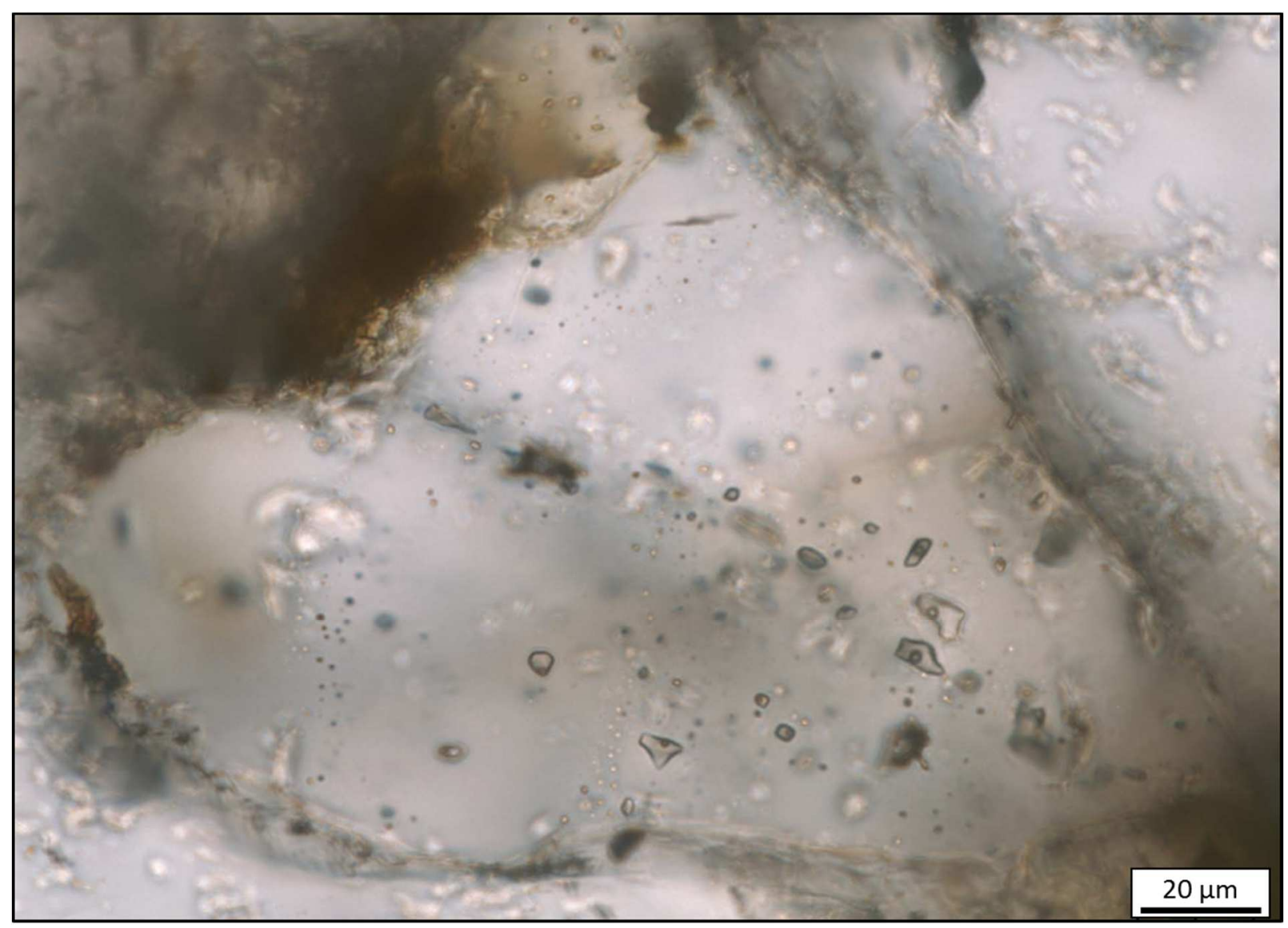

Figure 22. This image shows abundant liquid-vapor primary(?) fluid inclusions within a crystal of late quartz in STC 12A. This photo was taken in plain transmitted light. 


\section{Fluid Inclusion Microthermometry}

Heating runs were attempted on four liquid-vapor inclusions within the primary fluid inclusion assemblage identified in the large blocky calcite of sample STC 12B to determine homogenization temperatures for the fluids. Three cycling runs to determine a homogenization temperature were conducted, in which the observed inclusions were warmed at approximately $2.0^{\circ} \mathrm{C} /$ minute until the vapor bubbles within the inclusions started to shrink. The rate of warming was then reduced to approximately $1.0^{\circ} \mathrm{C} /$ minute as the vapor bubbles continued to reduce in size. Once the vapor bubbles reduced in size to approximately half of their original volume, the rate of warming was reduced further to approximately $0.1^{\circ} \mathrm{C} /$ minute.

As the inclusions were heated in the first run, the vapor bubbles within them started to get smaller and became difficult to see due to the small size of the inclusions and the double refraction of the calcite. At approximately $52.0^{\circ} \mathrm{C}$ during the first heating run, the vapor bubbles in each of the four observed inclusions were no longer visible and heating was stopped to avoid stretching of the inclusions. Once heating was stopped and the inclusions were cooled at approximately $0.1^{\circ} \mathrm{C} /$ minute, it was difficult to observe whether the vapor bubbles reappeared suddenly or gradually returned within each of the observed inclusions. A second attempt at heating the inclusions at the same warming rates resulted in the vapor bubbles no longer visible at approximately $51.8^{\circ} \mathrm{C}$ and heating was again stopped due to risk of stretching and it was undetermined if the vapor bubbles reappeared suddenly or gradually.

A homogenization temperature was not identified due to the inability to view the vapor bubbles disappearing and gradually or suddenly reappearing confidently. However, a homogenization temperature of $\sim 52.0^{\circ} \mathrm{C}$ could be estimated because the vapor bubbles were no longer visible. Freezing/melting runs were not conducted on this sample because of the small 
size of the inclusions. Heating and freezing/melting runs were not conducted on the primary inclusions found in the calcite of STC 12A due to the small size of the inclusions.

\section{Stable Isotope Analysis}

Isotope data for STC 12A is summarized in Table 4 and illustrated in Figure 24.

Locations sampled from STC 12A are shown in Figure 23. Three locations were sampled within the host rock, all yielding similar $\delta^{18} \mathrm{O}$ and $\delta^{13} \mathrm{C}$ values. Oxygen values increased from the host rock margin toward the center, then decreased again within the blocky calcite at the center of the vein.

\begin{tabular}{|l|c|c|}
\hline \multicolumn{3}{|c|}{ STC 12A (J1?, Sant Corneli Sequence) } \\
\hline SAMPLE LOCATION & $\delta^{18}$ O (\%) VPDB & $\delta^{13} \mathrm{C}(\%)$ VPDB \\
\hline Blocky Calcite (Vein) & -12.3 & 1.0 \\
\hline Elongate Blocky Calcite(Center of vein) & -10.1 & 2.1 \\
\hline Elongate Blocky Calcite (Near host rock) & -10.6 & 2.4 \\
\hline Host 1 (Adjacent to vein) & -8.2 & 2.2 \\
\hline Host 2 & -7.9 & 2.1 \\
\hline Host 3 & -8.2 & 2.3 \\
\hline
\end{tabular}

Table 4. Isotope data for STC 12A. 


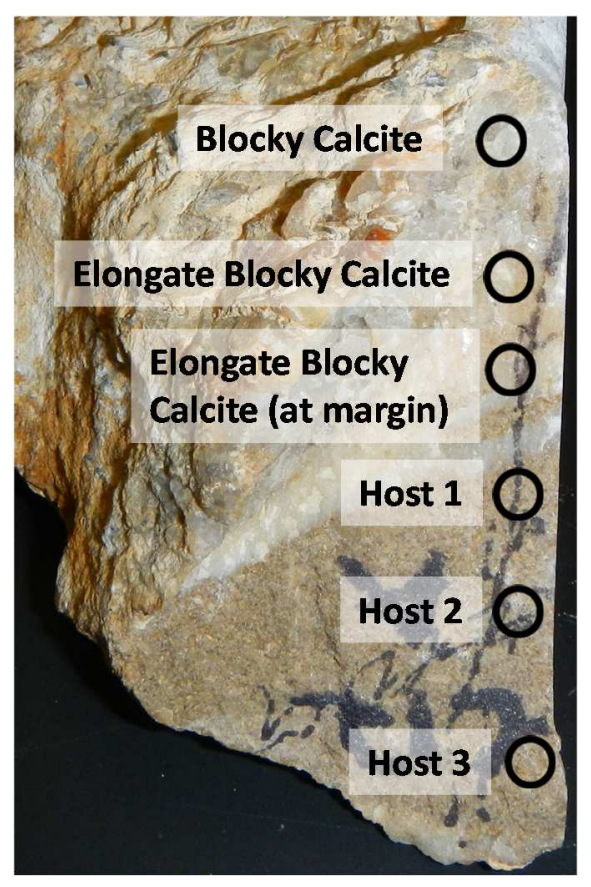

Figure 23. Schematic image illustrating isotope sample locations for STC 12A.

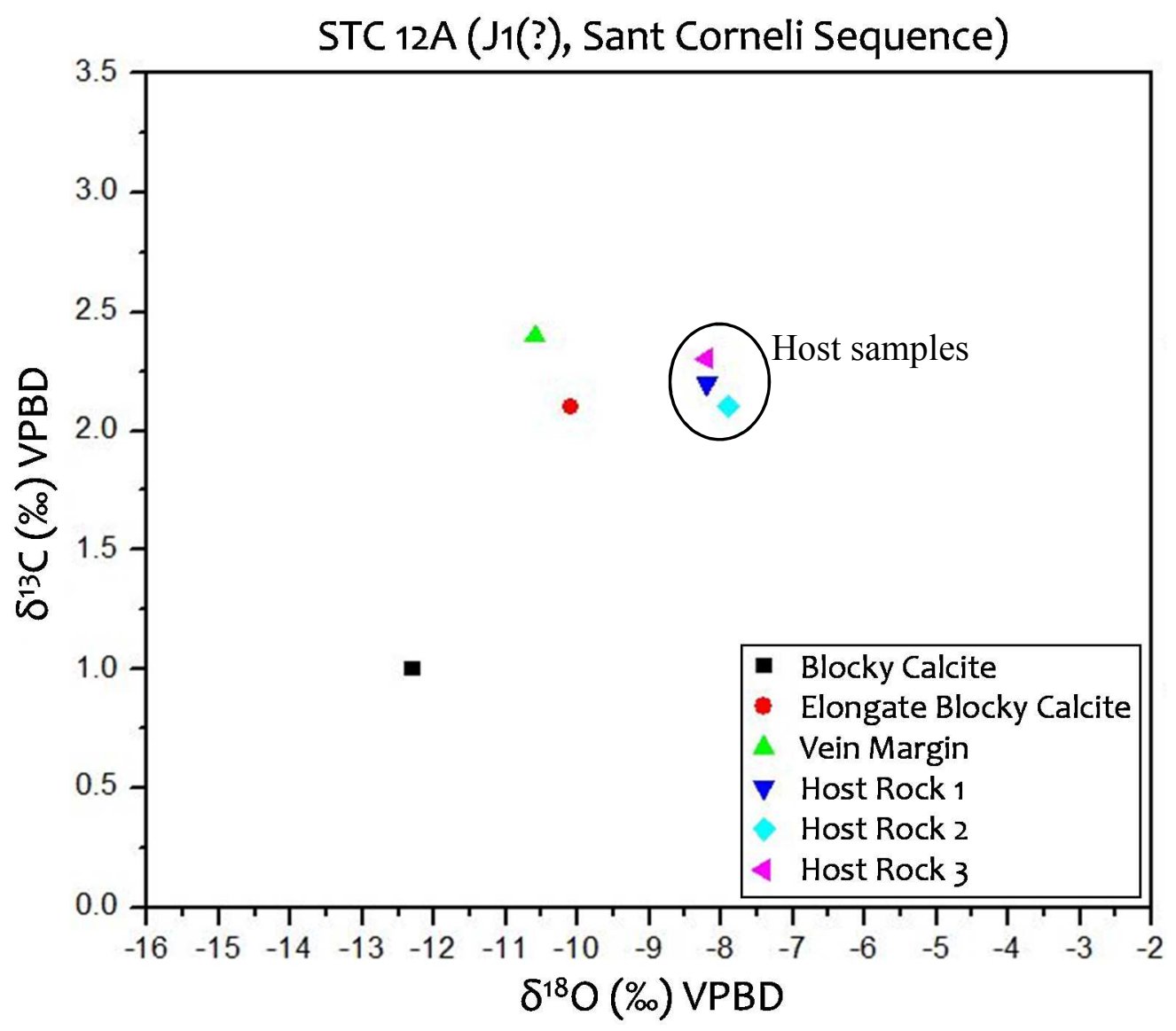

Figure 24. Plot of $\delta^{18} \mathrm{O}$ vs. $\delta^{13} \mathrm{C}$ isotope data for STC $12 \mathrm{~A}$. Values for both $\delta^{18} \mathrm{O}$ and $\delta^{13} \mathrm{C}$ are reported with respect to VPDB in per mil (\%o). 
Isotope data for STC 12B is summarized in Table 5 and illustrated in Figure 26.

Locations sampled from STC 12B are shown in Figure 25. Isotope data for the three locations sampled within the host rock showed very little variation. Oxygen isotope values within the blocky calcite were significantly lower than those of the adjacent host rock, while the carbon isotope values for the cement were higher than those of the host rock.

\begin{tabular}{|l|c|c|}
\hline \multicolumn{3}{|c|}{ STC 12B (J3?, Sant Corneli Sequence) } \\
\hline Sample Location & $\delta^{18}$ O (\%) VPDB & $\delta^{13} \mathrm{C}(\% \circ)$ VPDB \\
\hline Large Blocky Calcite & -15.6 & 2.8 \\
\hline Host 1 & -8.0 & 1.6 \\
\hline Host 2 & -8.9 & 1.9 \\
\hline Host 3 & -9.1 & 2.3 \\
\hline
\end{tabular}

Table 5. Isotope data for STC 12B.

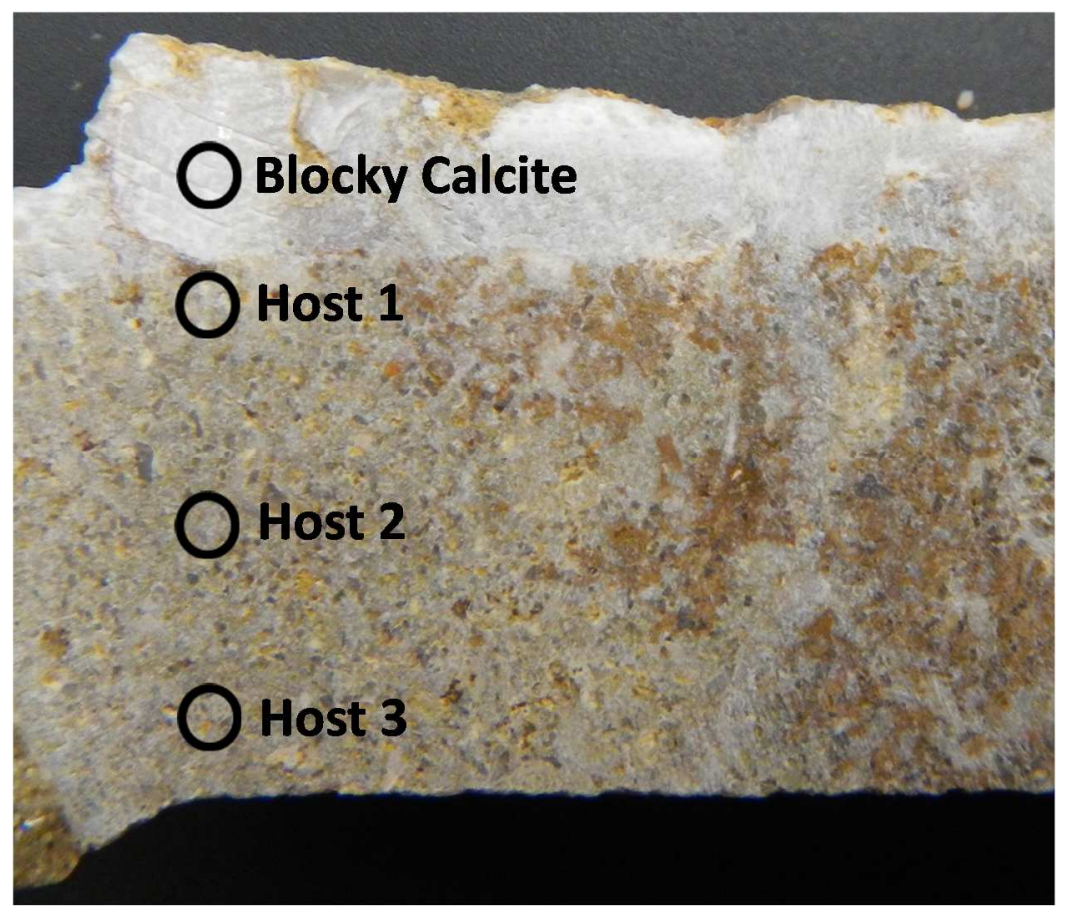

Figure 25. Schematic image illustrating isotope sampling locations for STC 12B. 


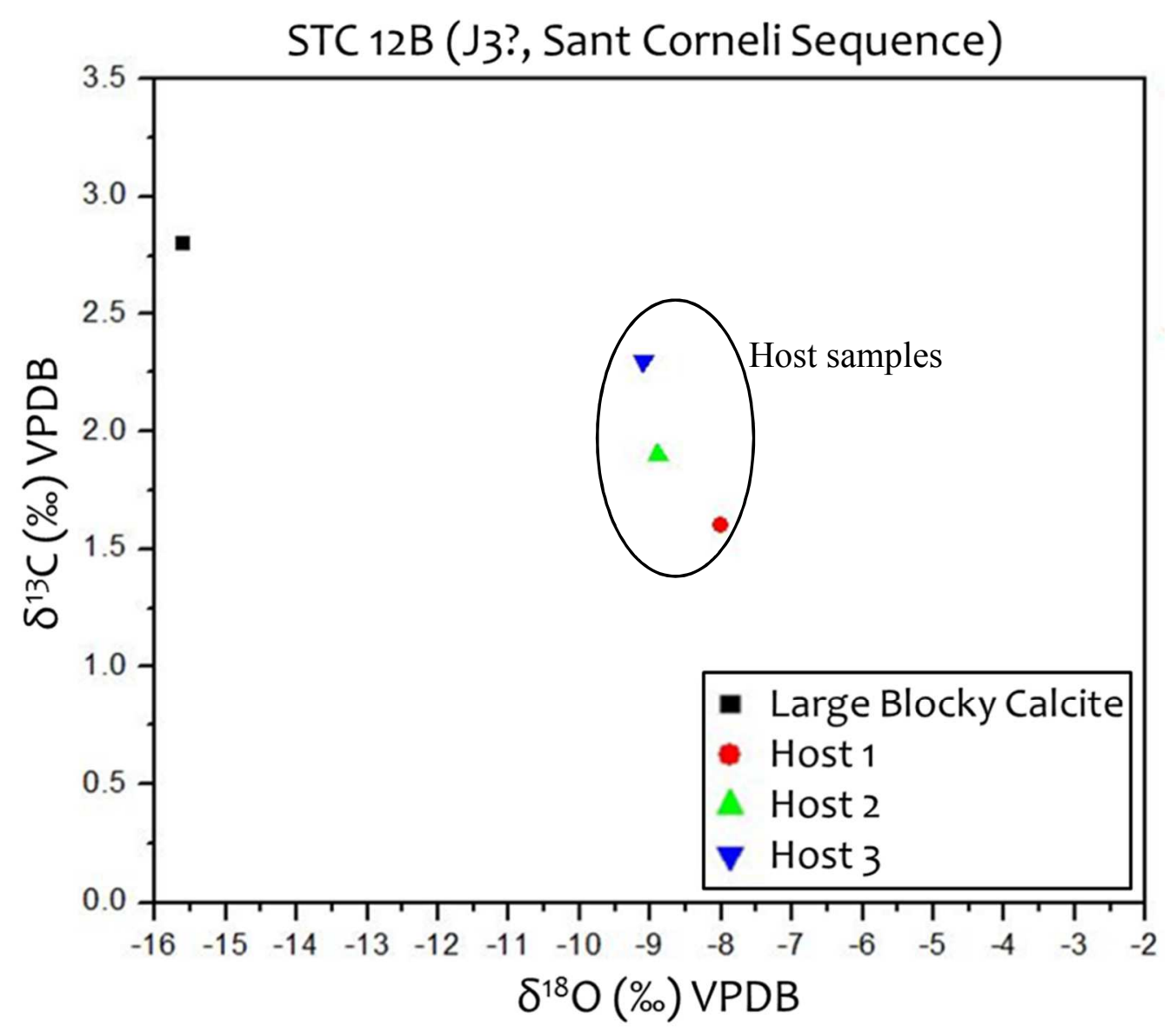

Figure 26. Plot of $\delta^{18} \mathrm{O}$ vs. $\delta^{13} \mathrm{C}$ isotope data for STC 12B. Values for both $\delta^{18} \mathrm{O}$ and $\delta^{13} \mathrm{C}$ are reported with respect to VPDB in per mil (\%).

\subsection{J2 Set:}

\section{Thin Section Petrography}

Sample STC 6 (Fig. 27-29) was sampled from the J2 vein set in the Orcau-Vell sequence of the Aren group on the forelimb of the anticline just north of Orcau (see Fig. 10 for location). This sample exhibits a very thin generation of drusy calcite followed by fibrous to elongate blocky calcite cement. A younger generation of small blocky calcite cement appears to have followed, potentially filling in areas of dissolution. The paragenetic sequence for STC 6 is summarized in Table 6 and illustrated in Figure 29. The fibrous to elongate blocky generation of 
cement is curved, similar to the elongate blocky cement observed in sample STC 12A. The blocky calcite is clear, while the elongate blocky cement is a cloudy, milky white. There is a minimal amount of iron oxides present within the host rock, but does not appear to be in the vein cements; pieces of the host rock stained with iron oxides are observed within the calcite cements (highlighted in Fig. $28 \& 29$ ). There does not appear to be any late quartz present in the vein.

\begin{tabular}{|l|c|}
\hline STC 6 (J2, Aren Group) & \multicolumn{2}{|c|}{ Generation of Cement } \\
\hline CEMENT TYPE & EARLY \\
\hline Drusy Calcite & $\square$ \\
\hline Small Blocky Calcite & \\
\hline Elongate Blocky Calcite & \\
\hline Fibrous Calcite & \\
\hline Iron oxide staining & \\
\hline
\end{tabular}

Table 6. Paragenetic sequence of cement precipitation for sample STC 6. 


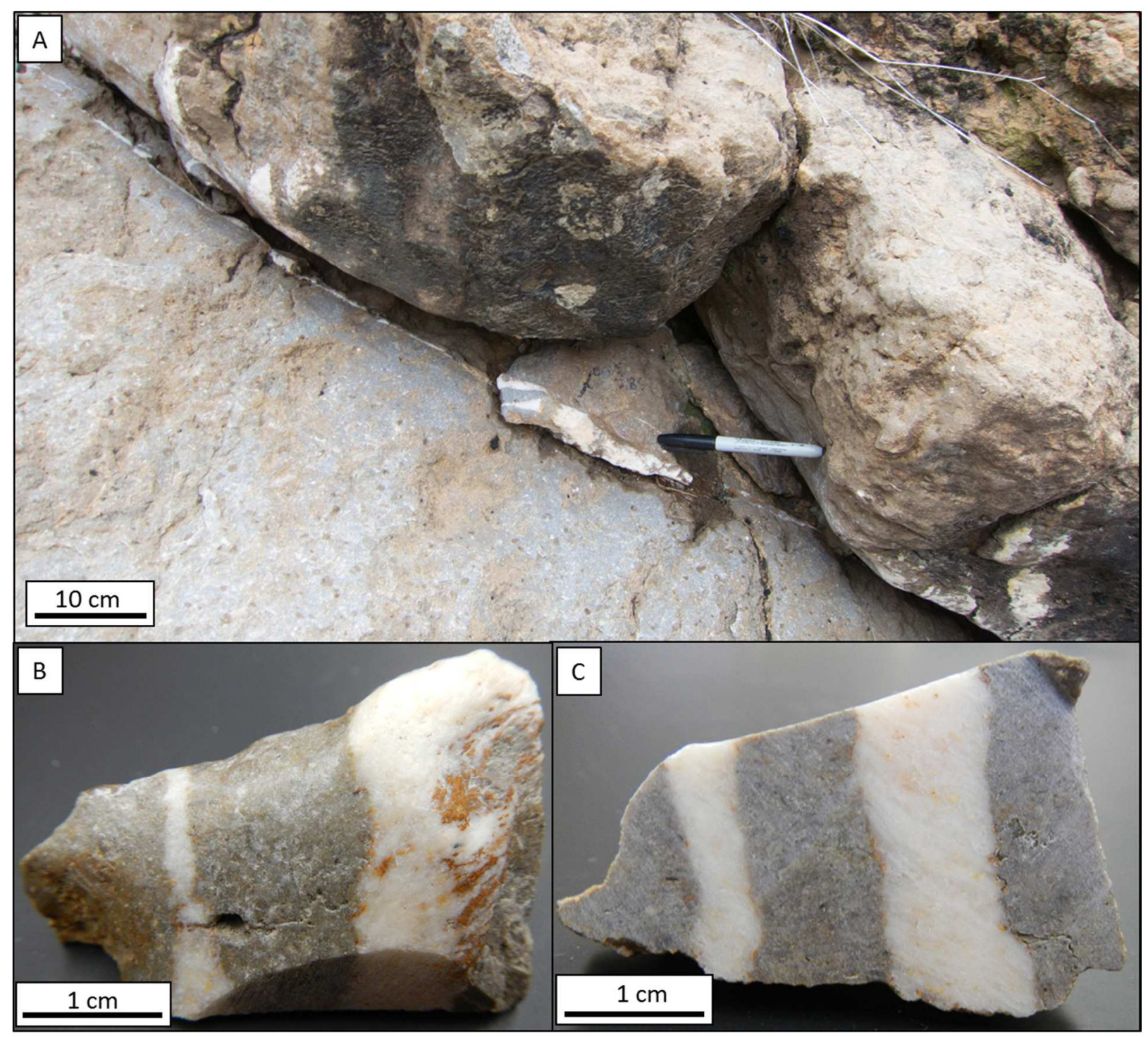

Figure 27. Images of sample STC 6 in outcrop and hand sample. Box A shows the outcrop sampled, while boxes B and C show the hand sample of STC 6, both the raw surface and cut surface. 


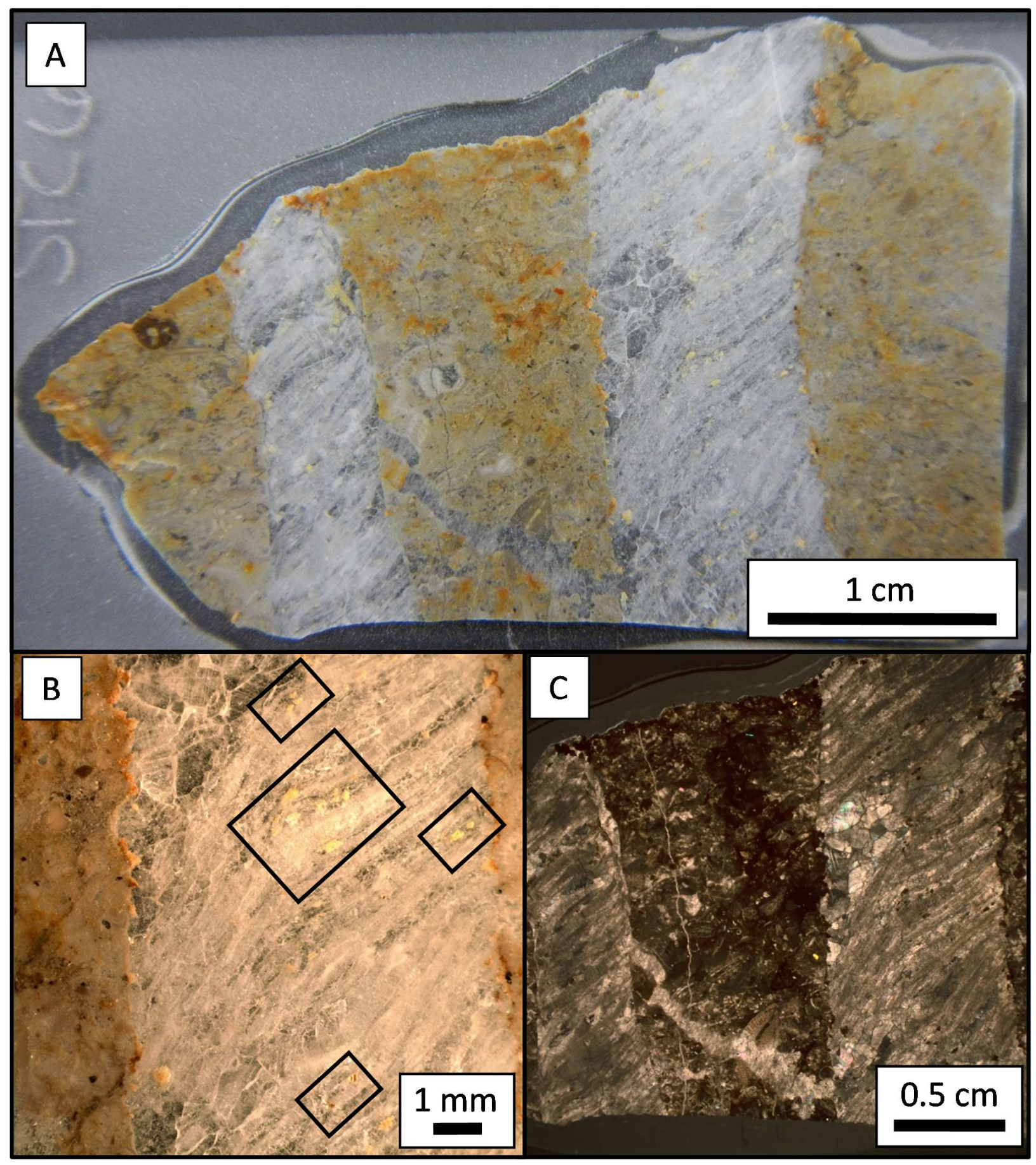

Figure 28. The full thin-section of sample STC 6 in plain light is shown in Box A. Box B shows a close-up of the curved elongate blocky to fibrous calcite cement and isopachous small to large blocky calcite in plain transmitted light. Pieces of host rock trapped during vein growth are highlighted by black boxes in Box B. Box C is an image of the sample in cross-polarized light. 


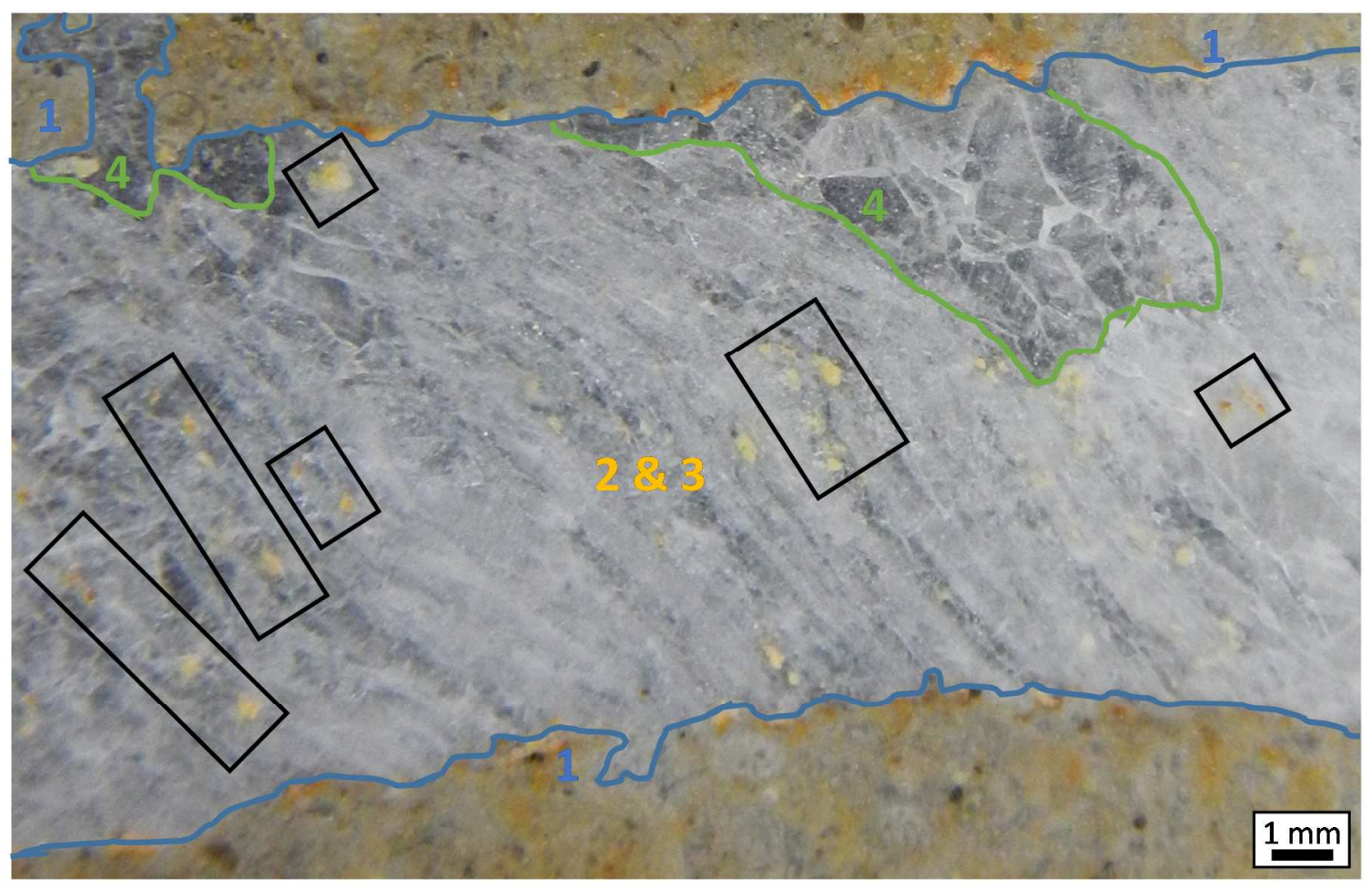

4 - Small blocky calcite

2 \& 3 - Elongate blocky and fibrous calcite 1 - Drusy calcite

Figure 29. Schematic diagram of the different cement generations observed in sample STC 6. The very thin layer of drusy calcite is outlined in blue. The small blocky calcite cement is bounded in green, and the cements in the center (labeled in yellow as $2 \& 3$ ) are fibrous to elongate blocky calcite. The fibrous calcite cement exhibits smooth crystal boundaries, while the elongate blocky calcite does not. The yellowish specks highlighted by black boxes are pieces of the host rock that were trapped in the calcite during vein formation (also shown in Fig. 27).

\section{Fluid Inclusion Petrography}

Fluid inclusions were abundant in STC 6. However, many of them were so small that they were difficult to see. Primary fluid inclusion assemblages were also difficult to distinguish from secondary and pseudosecondary fluid inclusion assemblages due to the small size of the inclusions and their abundant distribution throughout the sample. One primary fluid inclusion assemblage (1) was identified along a growth boundary in the small blocky calcite cement (Fig. 30, top image). The individual inclusions in this primary assemblage were difficult to see, 
generally ranging from less than one micron to a few microns in size. The inclusions were all elongate rectangular to rounded in shape. A few of the larger inclusions in the assemblage appeared to contain both liquid and vapor phases of similar ratios; however, the phases in the smaller inclusions were unidentifiable.

Several secondary/pseudosecondary fluid inclusion assemblages have also been identified in relation to the primary fluid inclusion assemblage discussed above. These secondary/pseudosecondary inclusion assemblages have been highlighted in the lower two images of Figure 30. One inclusion assemblage (2) is likely a pseudosecondary assemblage, as there's no evidence that it cuts across the primary inclusion assemblage. Another inclusion assemblage (3) is most likely a secondary fluid inclusion assemblage because it cuts across the primary assemblage (1) as well as the pseudosecondary assemblage (2). When observed under UV light, there was no fluorescence visible within any of the observed inclusions. 


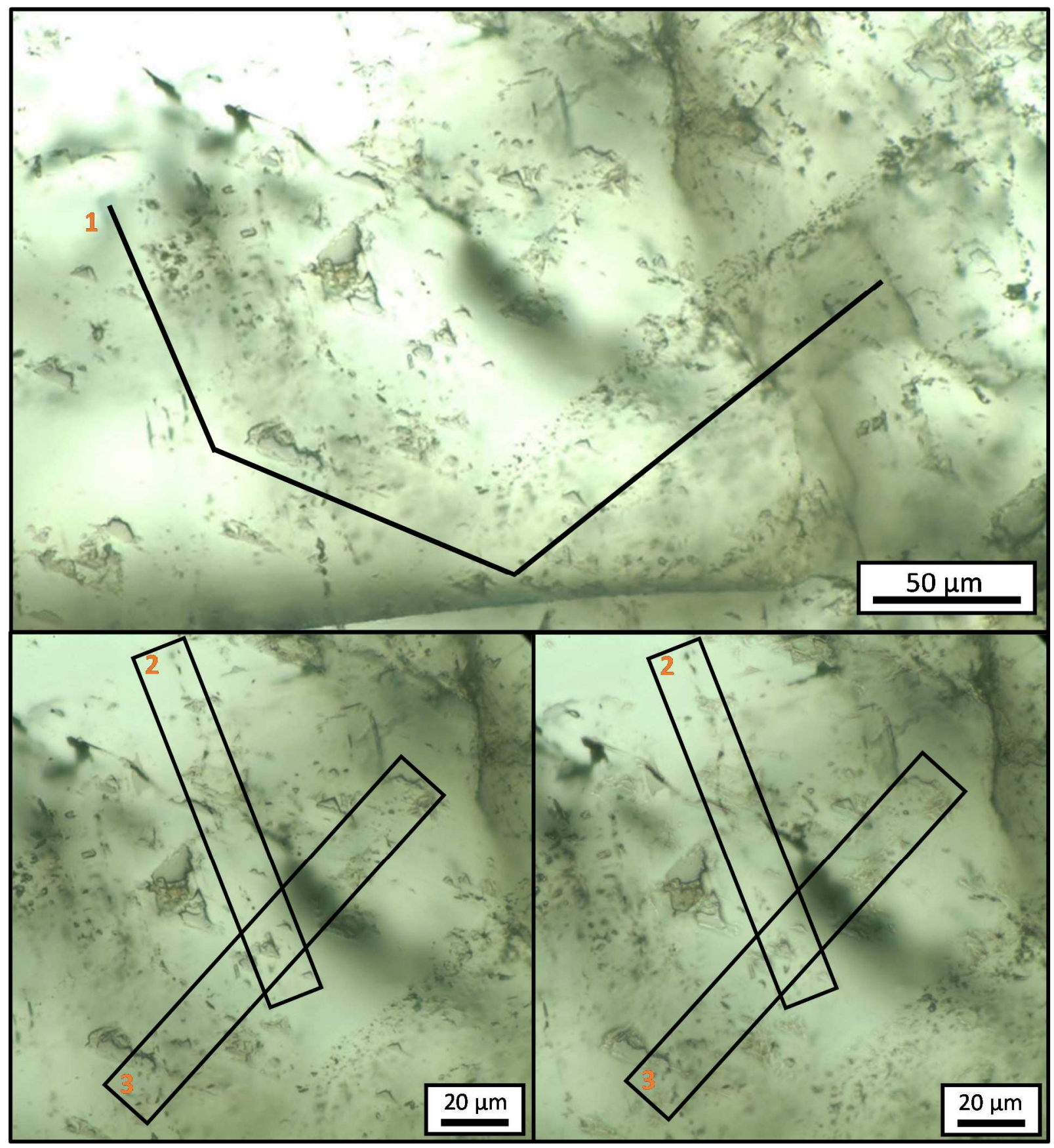

Figure 30. Photomicrographs of primary and secondary/pseudosecondary fluid inclusion assemblages in STC 6. The primary fluid inclusion assemblage (1) is outlined in black in the top image, and forms a growth boundary. A pseudosecondary FIA (2) and a secondary FIA (3) are outlined in black in the bottom two images. 


\section{Fluid Inclusion Microthermometry}

Fluid inclusion microthermometric analyses were not conducted on this sample. The inclusions were too small to distinguish the phases present at room temperature; therefore, phase changes during heating and freezing/melting runs would not be discernable.

\section{Stable Isotope Analysis}

Oxygen and carbon isotope analyses were conducted on the calcite vein and host rock of sample STC 6. The results are summarized in Table 7 and illustrated in Figure 32. Locations sampled along STC 6 for isotope analyses are shown in Figure 31. Carbon and oxygen isotope values vary little within the host rock. The elongate blocky calcite exhibits lower $\delta^{13} \mathrm{C}$ and $\delta^{18} \mathrm{O}$ values in comparison to the adjacent host rock.

\begin{tabular}{|l|c|c|}
\hline \multicolumn{3}{|c|}{ STC 6 (J2, Aren Group) } \\
\hline Sample Location & $\delta^{18}$ O (\%) VPDB & $\delta^{13} \mathrm{C}(\% \circ)$ VPDB \\
\hline Elongate Blocky Calcite & -7.7 & 0.8 \\
\hline Host 1 & -4.7 & 1.3 \\
\hline Host 2 & -4.2 & 1.1 \\
\hline Host 3 & -4.2 & 1.2 \\
\hline
\end{tabular}

Table 7. Isotope data for STC 6. 


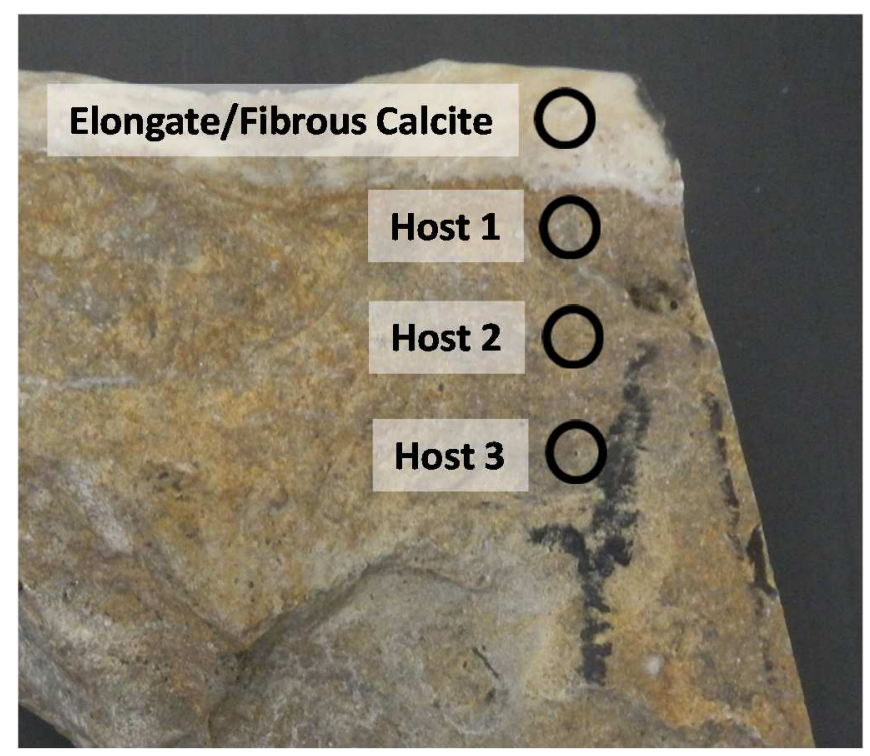

Figure 31. Schematic image showing locations sampled for isotope analyses of STC 6.

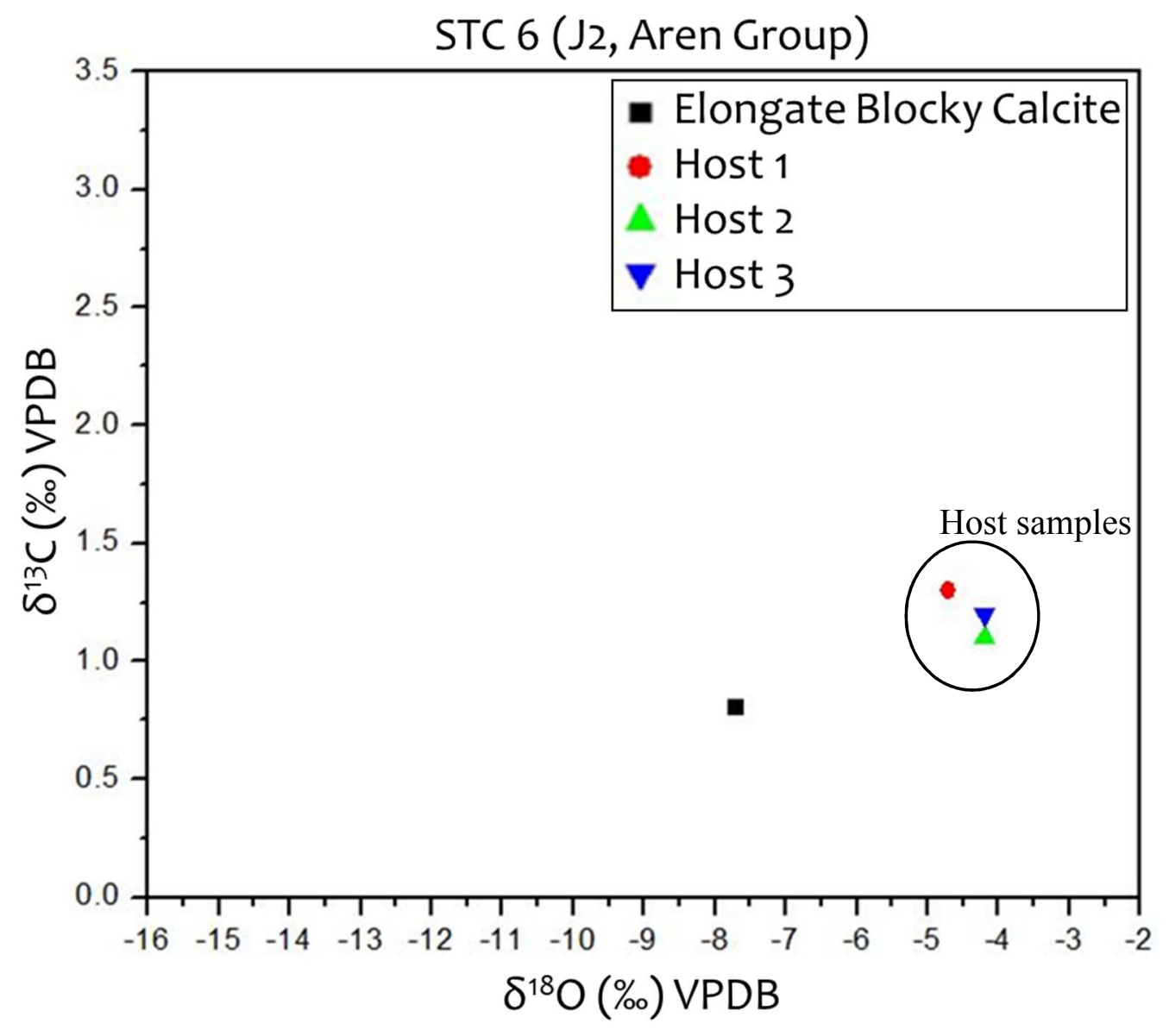

Figure 32. Plot of $\delta^{18} \mathrm{O}$ vs. $\delta^{13} \mathrm{C}$ isotope data for STC 6. Values for both $\delta^{18} \mathrm{O}$ and $\delta^{13} \mathrm{C}$ are reported with respect to VPDB in per mil (\%). 


\section{$4.3 \mathrm{~J} 4$ Set:}

\section{Thin Section Petrography}

Sample STC 13 (Figures 33-35) was analyzed from the J4 vein set, sampled from the Sant Corneli sequence on the backlimb of the anticline. This sample is characterized by two distinct generations of iron oxide cements within the host rock, adjacent to the calcite cement. Directly adjacent to the calcite is a dark red hematite cement, followed by a rusty orange goethite cement farther into the host rock (see Fig. 34, box C). The goethite cement is most likely older than the hematite cement, as cements typically form from the margin of a vein toward the center. These iron oxide cements are not present within any of the calcite cements in the vein. The vein is composed of two generations of clear calcite cement. The first generation adjacent to the host rock is a thin layer of isopachous small blocky calcite, followed by a second generation of isopachous large blocky calcite. The paragenetic sequence for STC 13 is summarized in Table 8 and illustrated in Figure 35. This sample also contains a late generation of quartz that filled in pockets of dissolved calcite in both the small blocky and large blocky calcite generations. An example of the late stage quartz cement is shown in Figure 36.

\begin{tabular}{|c|c|c|c|}
\hline \multirow{2}{*}{$\begin{array}{l}\text { STC } 13 \text { (J4, Sant Corneli Sequence) } \\
\text { CEMENT TYPE }\end{array}$} & \multicolumn{3}{|c|}{ Generation of Cement } \\
\hline & EARLY & MIDDLE & LATE \\
\hline Drusy Calcite & $\square$ & & \\
\hline Small Blocky Calcite & & & \\
\hline Large Blocky Calcite & & 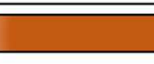 & \\
\hline Quartz & & & $\square$ \\
\hline Hematite & & & $?$ \\
\hline Goethite & & & $? \square$ \\
\hline
\end{tabular}

Table 8. Paragenetic sequence of cements for sample STC 13. 


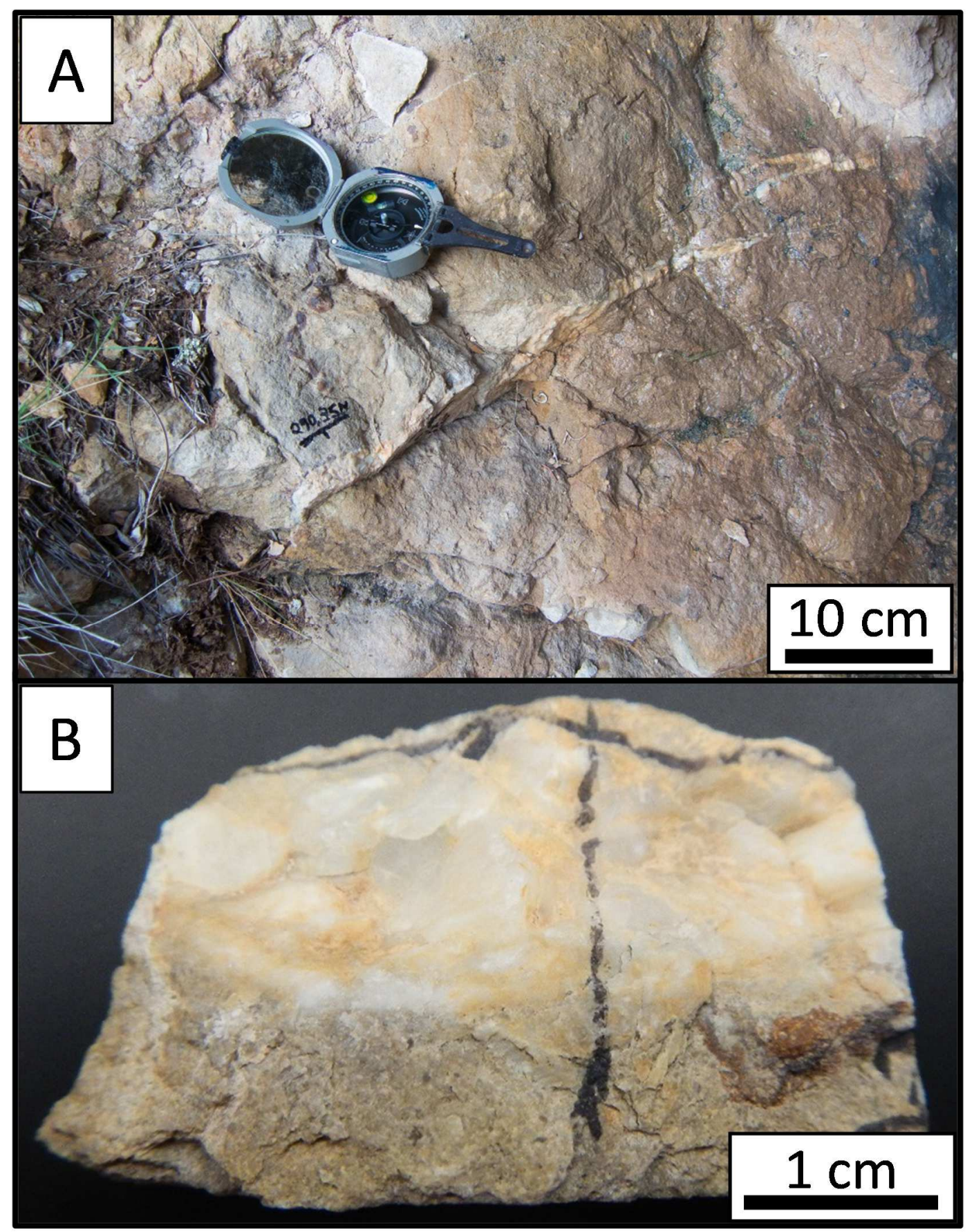

Figure 33. Images of outcrop and hand samples of STC 13. An image of the vein in outcrop is shown in the top box (A), while a hand sample is shown in the bottom box (B). 


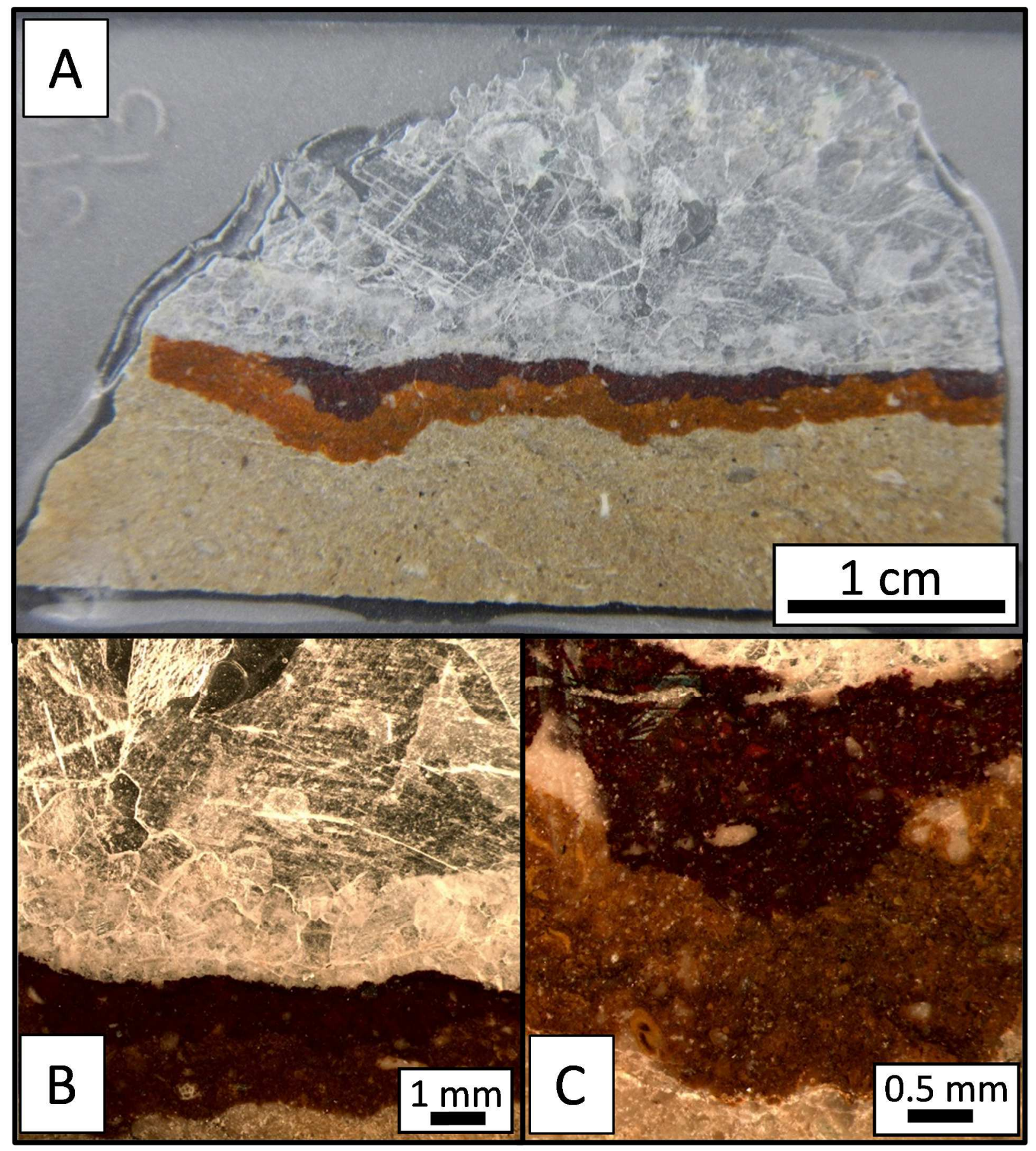

Figure 34. Photomicrographs of STC 13. The top image (Box A) shows the full thin section of the sample. The lower right image (Box B) highlights the small blocky and large blocky calcite cements. An up-close view of the goethite and hematite cements is shown in the lower right image (Box C). 


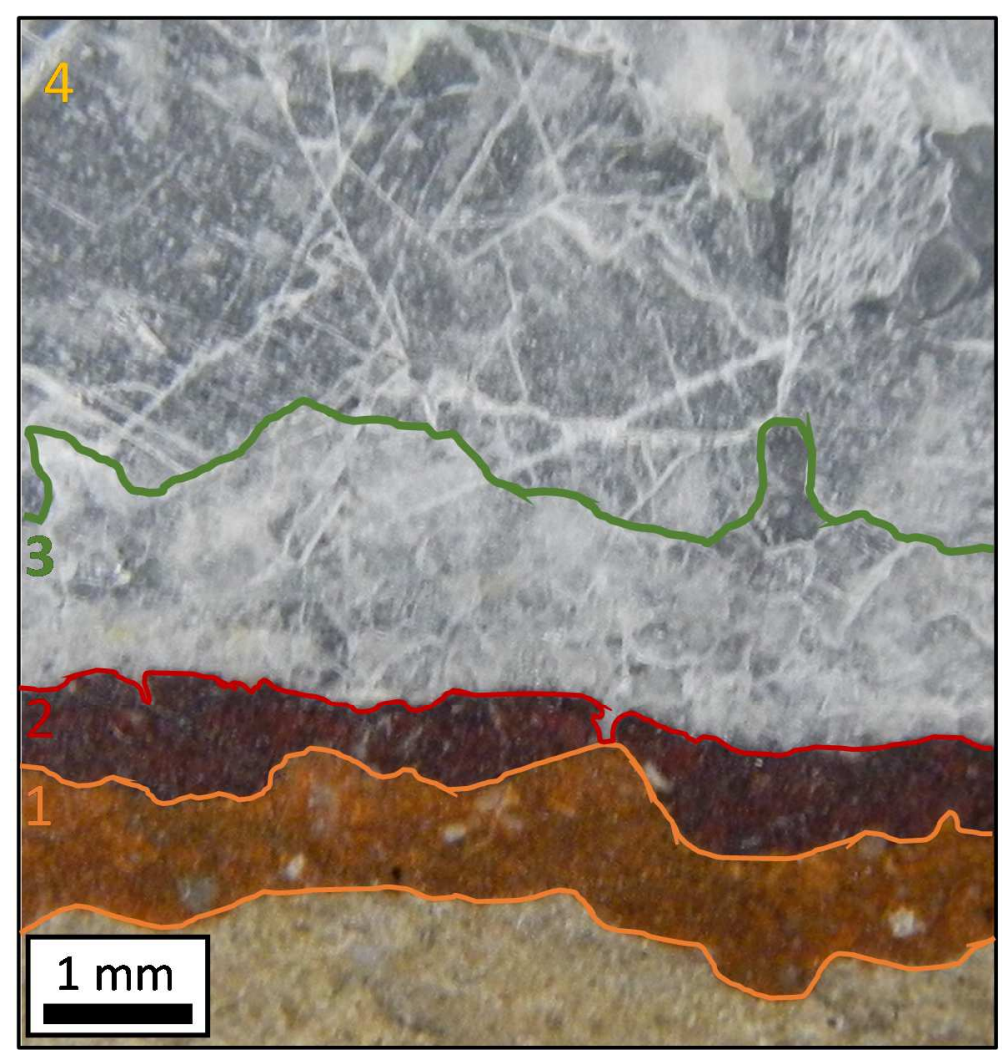

4 - Large blocky calcite cement

3- Small blocky calcite cement

2 - Hematite cement

1 - Goethite cement

Figure 35. A schematic image outlining each of the vein cements observed in STC 13. Goethite cement is outlined in orange and hematite cement is outlined in red. Small blocky calcite cement is outlined in green, and large blocky calcite is labeled above the top of the small blocky calcite. The later quartz cement is not shown in this image due to the small size of the quartz crystals.

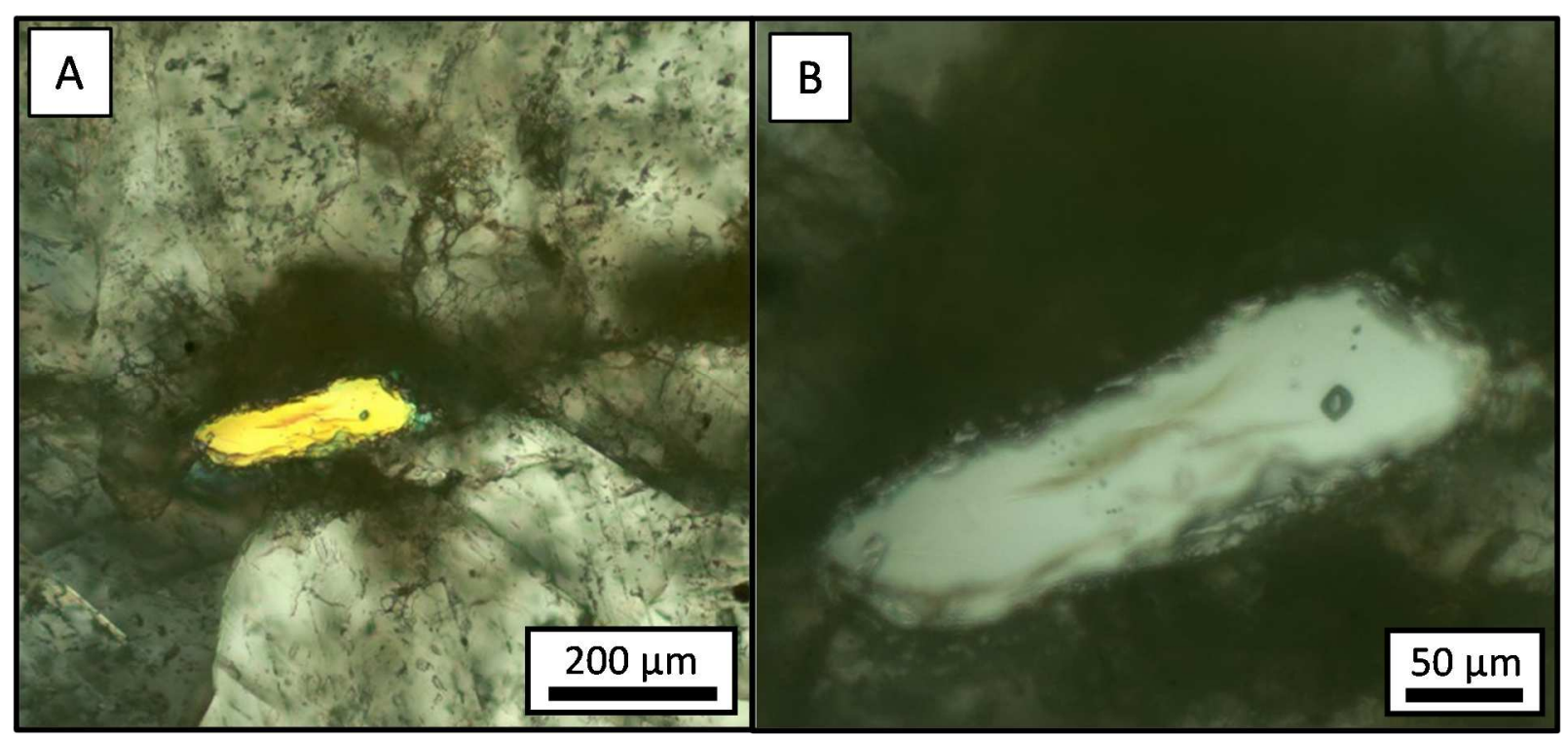

Figure 36. An example of the late quartz cement seen in STC 13. The image in box A shows a crystal of quartz cement surrounded by small blocky calcite cement in cross-polarized light. The image in box B is a closer look at the same crystal in plain transmitted light. 


\section{Fluid Inclusion Petrography}

A distinct primary fluid inclusion assemblage (1) was observed in the small blocky calcite of STC 13 (Fig. 37). The assemblage falls along a growth plane that exhibits typical calcite crystal habit. The fluid inclusions within this assemblage were very small, ranging from approximately $<1 \mu \mathrm{m}$ to $\sim 2 \mu \mathrm{m}$ in size. The inclusions all appeared to be similar in shape, exhibiting an elongate oval to elongate rectangular shape with curved corners. The larger inclusions were two-phase liquid-vapor fluid inclusions. The phases present within the smaller inclusions were not determined, as they were too small to distinguish if there was a vapor bubble present.

Another assemblage of inclusions (2) was observed at the same location as the primary fluid inclusion assemblage. This assemblage appears to terminate against the primary inclusion assemblage, indicating that these inclusions are likely pseudosecondary. These inclusions appear to be consistent in size, and also appear to be no larger than the smallest inclusions in the primary fluid inclusion assemblage. Due to these inclusions being so small, the phases present within the inclusions is indeterminate. These inclusions have a consistent, rounded shape.

Fluid inclusions were also observed within the crystals of the late quartz cement (Fig. 38). These inclusions were significantly larger than those observed in the calcite, ranging from approximately $1 \mu \mathrm{m}$ to $5 \mu \mathrm{m}$. The inclusions are all rounded and appear to have two phases present. Although the inclusions all exhibit both liquid and vapor ratios, the liquid to vapor ratios do not appear to be consistent across all inclusions. It was very difficult to discern any patterns to the inclusions, therefore making the identification of primary and secondary/pseudosecondary extremely difficult. There was no fluorescence within any of the observed fluid inclusions in the calcite or quartz cements. 


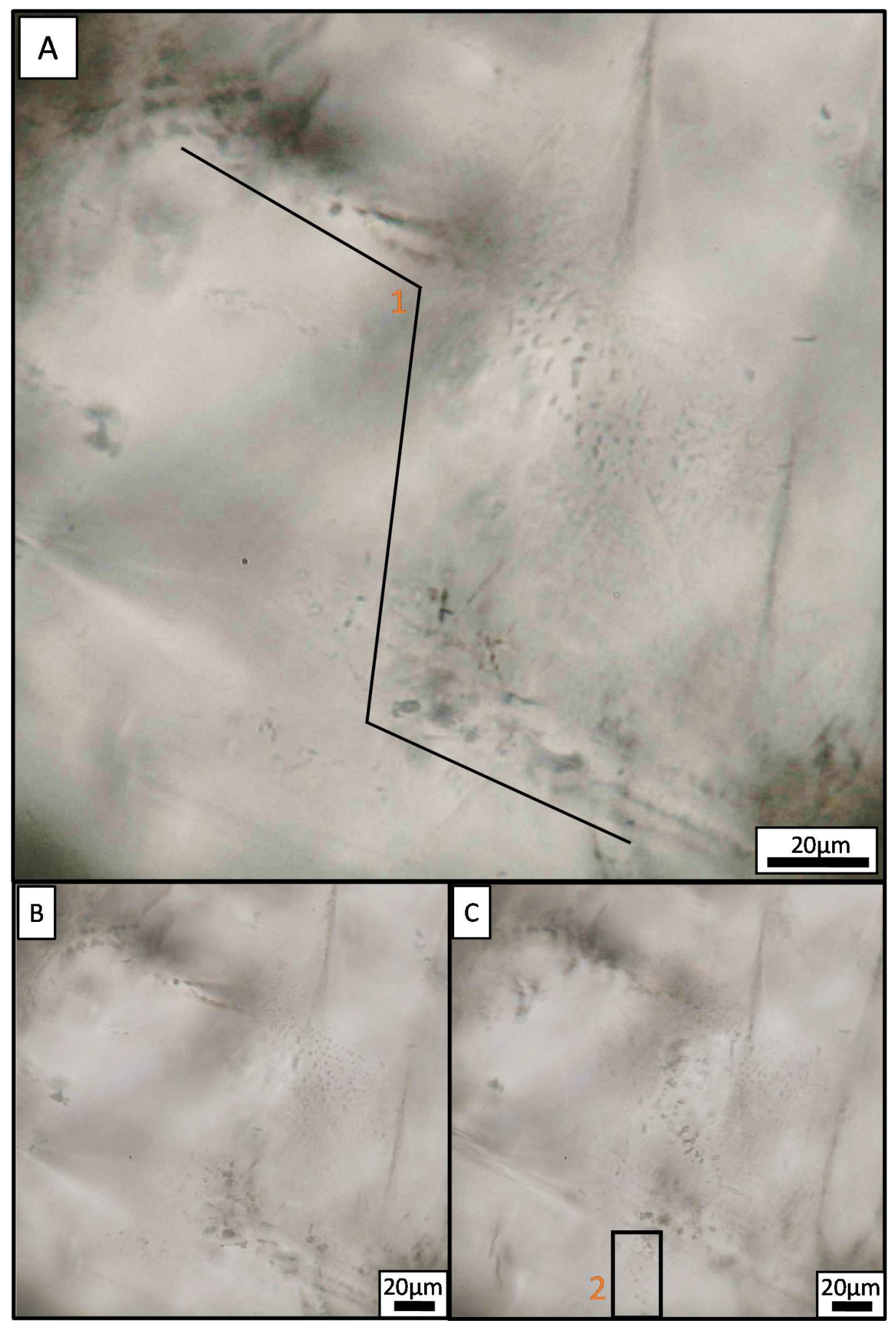

Figure 37. Images showing a primary fluid inclusion assemblage (1) that appears to fall along a growth boundary, as well as a secondary/pseudosecondary fluid inclusion assemblage (2) that abuts the primary assemblage. The primary assemblage (1) is outlined in the image in box A, and the secondary/pseudosecondary assemblage (2) is highlighted in box C. 


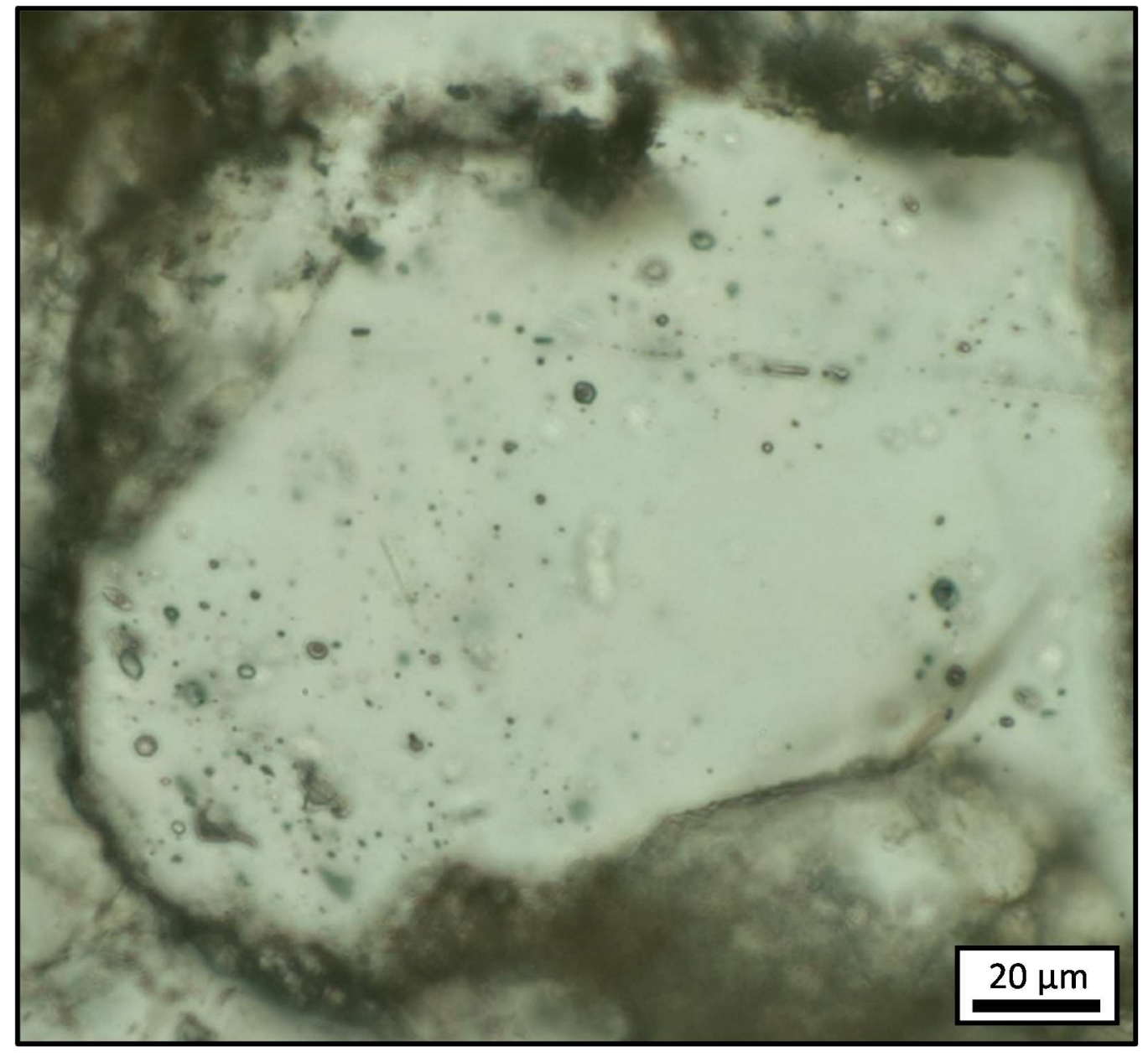

Figure 38. Image showing late stage quartz with abundant liquid-vapor primary(?) fluid inclusions in plain transmitted light. The inclusions appear scattered and random, making it difficult to determine the primary inclusion assemblage(s) from the secondary and pseudosecondary assemblages.

\section{Fluid Inclusion Microthermometry}

Fluid inclusion microthermometry was not attempted on the primary inclusions found within the calcite for STC 13. Due to the small size of the inclusions, heating and freezing/melting runs would not produce any data with confidence. 


\section{Stable Isotope Analysis}

Oxygen and carbon isotope analyses were performed on the calcite cements, iron oxide cements, and host rock of sample STC 13. The results are summarized in Table 9 and illustrated in Figure 39, while Figure 38 shows the locations along STC 13 that were sampled for analysis. Oxygen and carbon isotope values did not vary between the two host rock samples. The large and small blocky calcite cements exhibited nearly the same $\delta^{13} \mathrm{C}$ values; $\delta^{18} \mathrm{O}$ values for the small and large blocky calcite, however, differed significantly. Oxygen and carbon isotope values for the goethite cement were quite similar to the values for the small blocky cement. The hematite cement exhibited low isotope values for both oxygen and carbon.

\begin{tabular}{|l|c|c|}
\hline \multicolumn{3}{|c|}{ STC 13 (J4, Sant Corneli Sequence) } \\
\hline SAMPLE LOCATION & $\delta^{18}$ O (\%) VPDB & $\delta^{13} \mathrm{C}(\%)$ VPDB \\
\hline Large Blocky Calcite (Vein) & -14.5 & 2.5 \\
\hline Small Blocky Calcite (Vein) & -7.5 & 2.4 \\
\hline Goethite & -8.0 & 2.3 \\
\hline Hematite & -12.0 & 1.3 \\
\hline Host 1 (Adjacent to vein) & -6.9 & 3.0 \\
\hline Host 2 & -6.9 & 2.7 \\
\hline
\end{tabular}

Table 9. Isotope data for STC 13. 


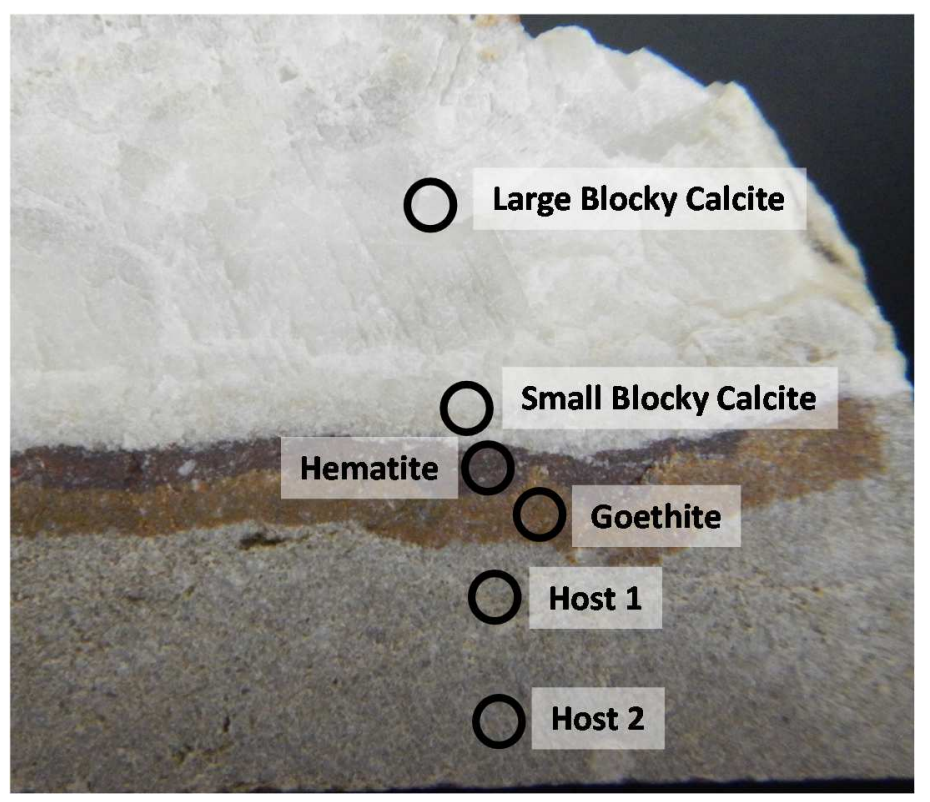

Figure 39. Schematic image showing locations sampled for isotope analyses for STC 13.

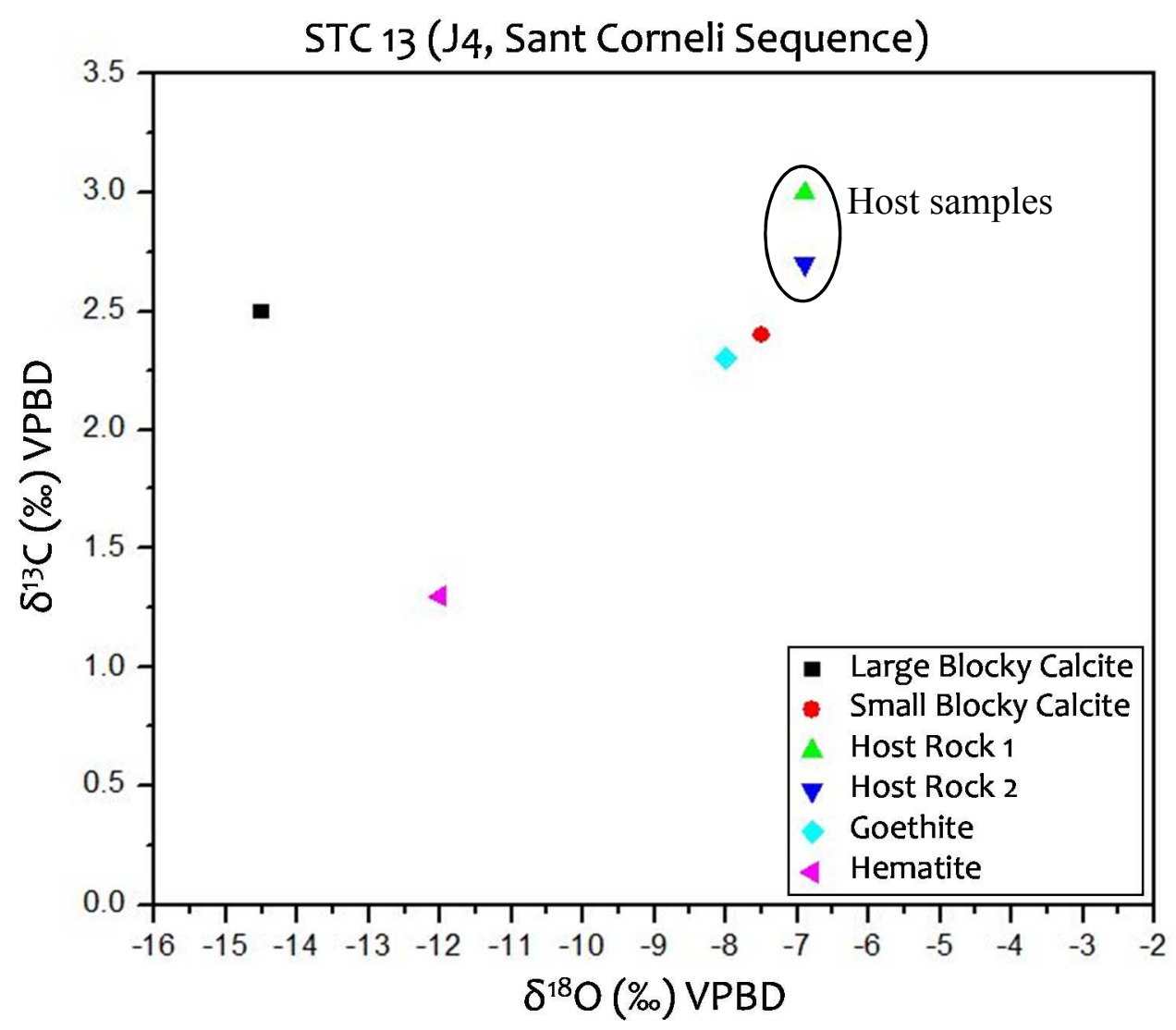

Figure 40. Plot of $\delta^{18} \mathrm{O}$ vs. $\delta^{13} \mathrm{C}$ isotope data for STC 13. Values for both $\delta^{18} \mathrm{O}$ and $\delta^{13} \mathrm{C}$ are reported with respect to VPDB in per mil (\%). 


\subsection{J5 Set:}

Thin Section Petrography

Sample STC 1 (Fig. 41-43) represents the J5 vein set, sampled from the Vallcarga sequence (see Fig. 10 for sample location). This sample is characterized by a first generation of isopachous drusy calcite, followed by small blocky calcite adjacent to the host rock and a generation of isopachous large blocky calcite toward the center of the vein. The drusy calcite cement forms a very thin lining along the vein-host rock interface. Both generations of blocky calcite are clear. There is a small amount of iron-oxide staining along the host rock-vein interface. There are small vugs at the center of the vein within the second generation of cement, possibly indicating some later dissolution event (see Fig. 42, Box B). The paragenetic sequence described below is summarized in Table 10 and illustrated in Figure 43.

\begin{tabular}{|l|c|}
\hline STC 1 (J5, Vallcarga Sequence) & \multicolumn{2}{|c|}{ Generation of Cement } \\
\hline CEMENT TYPE & EARLY \\
\hline Drusy Calcite & \multicolumn{2}{|}{} \\
\hline Small Blocky Calcite & \multicolumn{2}{|}{} \\
\hline Large Blocky Calcite & \\
\hline Iron Oxide Staining & \\
\hline
\end{tabular}

Table 10. Paragenetic sequence of cements for sample STC 1. 


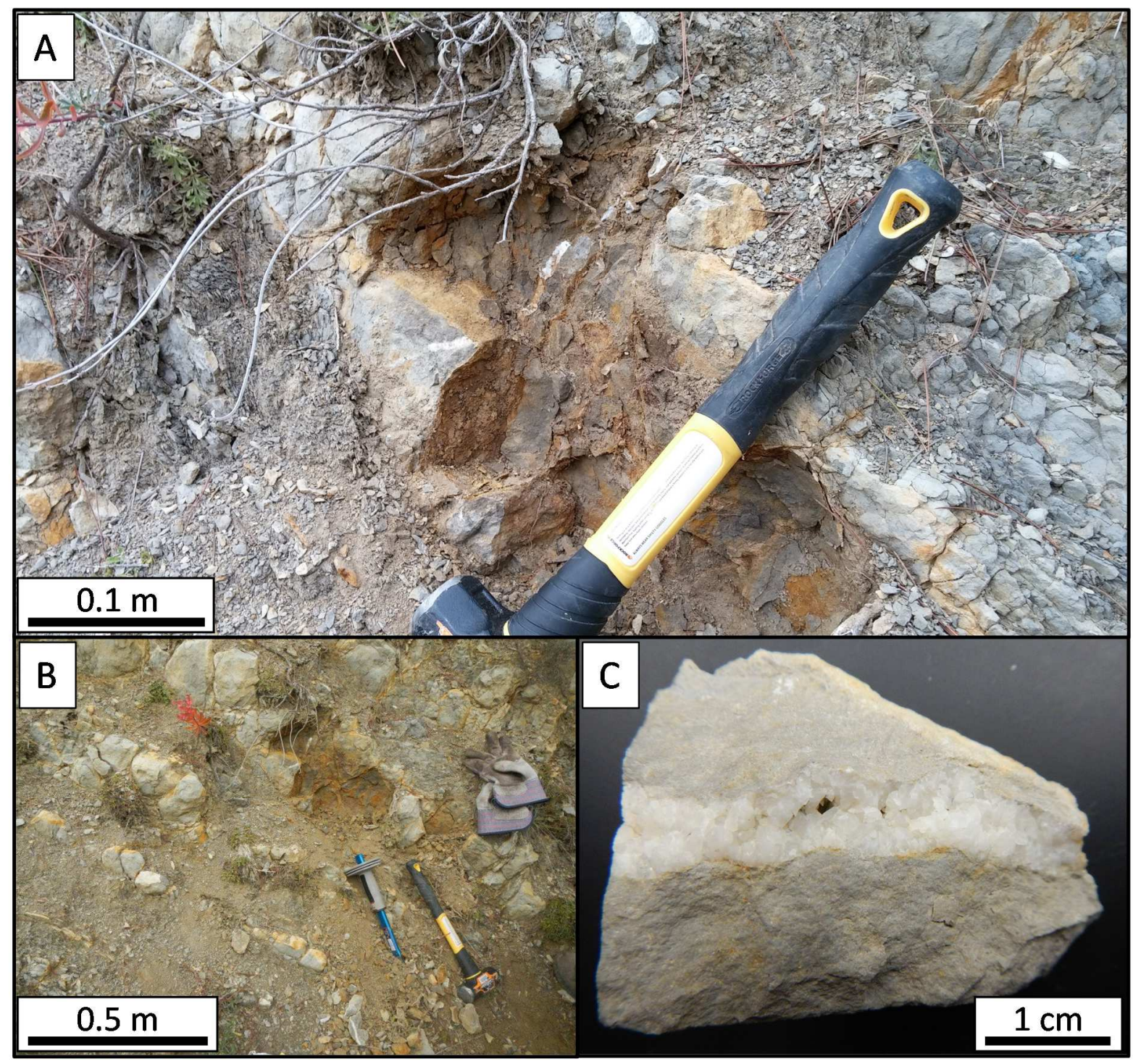

Figure 41. Field images of STC 1. The top photograph (Box A) shows close-up view of the outcrop sampled, while the lower left image (Box B) shows a larger-scale view of the outcrop. The image on the lower right (Box C) shows a hand sample of STC 1. 


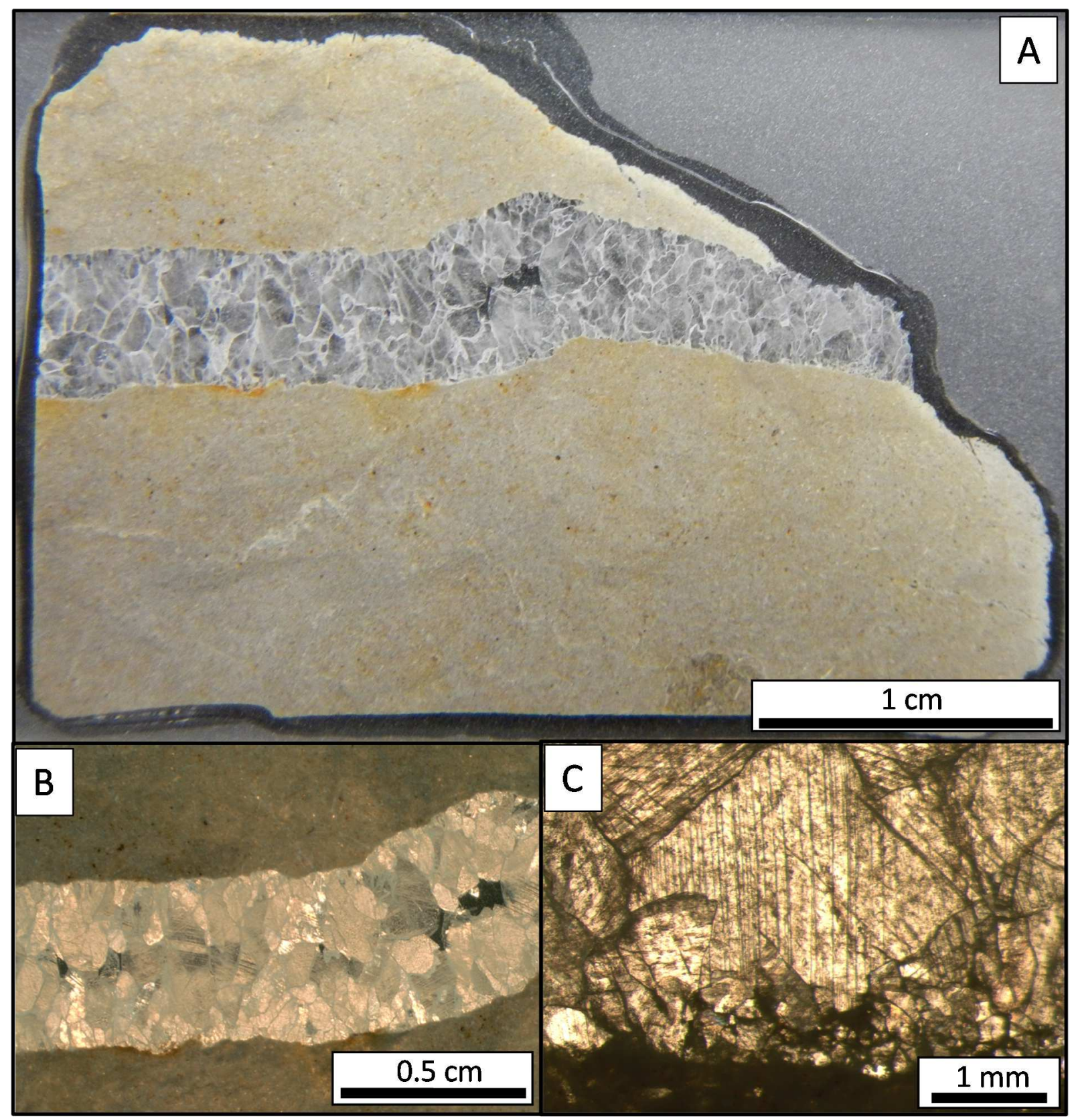

Figure 42. An image of the full thin section for sample STC 1 in plain light is shown in Box A. Box B highlights a vug in the center of the calcite vein, shown in reflected and transmitted plain polarized light. The isopachous small blocky calcite is shown in relation to the isopachous large blocky calcite in Box C. 


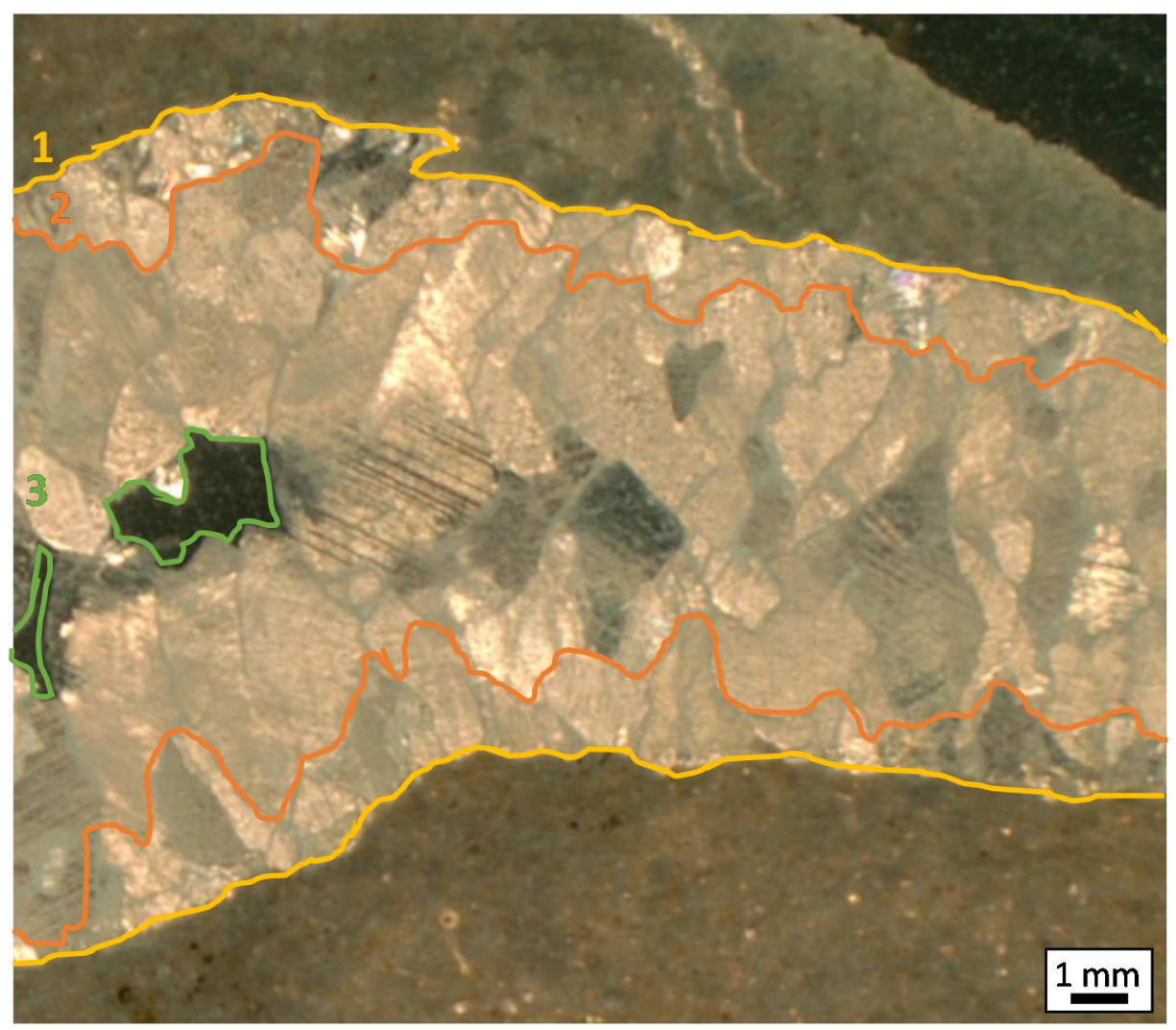

3 - Large blocky calcite

2-Small blocky calcite

1 - Drusy calcite

Figure 43. Schematic image of STC 1, outlining the calcite cement generations. Although the drusy calcite cement is a very thin layer, it is outlined in yellow. The top of the small blocky calcite cement is outlined in orange, and the large blocky calcite cement is between the two orange boundaries. Outlined in green are two small vugs within the large blocky calcite.

\section{Fluid Inclusion Petrography}

Fluid inclusions were plentiful in sample STC 1. However, as with sample STC 6, the inclusions were extremely small, generally less than a micron to a few microns in size, making them very hard to see. Identifying primary and secondary/pseudosecondary fluid inclusion assemblages was also very difficult due to the abundance and size of the inclusions. A primary fluid inclusion assemblage was identified in association with a secondary fluid inclusion assemblage in the small blocky calcite cement (Fig. 44). The primary fluid inclusion assemblage appears to be along a growth boundary (1) and is cut by the secondary fluid inclusion assemblage (3). Due to the small size of the inclusions and the double refraction property of the calcite 
crystal, the phases present within these inclusions is unknown. The inclusions in both the primary fluid inclusion assemblage and the secondary assemblage appear to be sub-rectangular to oval in shape. An undifferentiated inclusion was identified nearby the primary and secondary assemblages, and appears to be parallelogram-shaped with rounded corners. This undifferentiated inclusion also appears to contain both liquid and vapor phases, as it is larger than the inclusions observed in the primary and secondary inclusions. There was no fluorescence within the inclusions when viewed under UV light.

\section{Fluid Inclusion Microthermometry}

Fluid inclusion microthermometric analyses were not conducted on this sample due to the small size of the inclusions. The phases of the fluids present within the inclusions were indistinguishable at the maximum magnification usable with the fluid inclusion stage. 


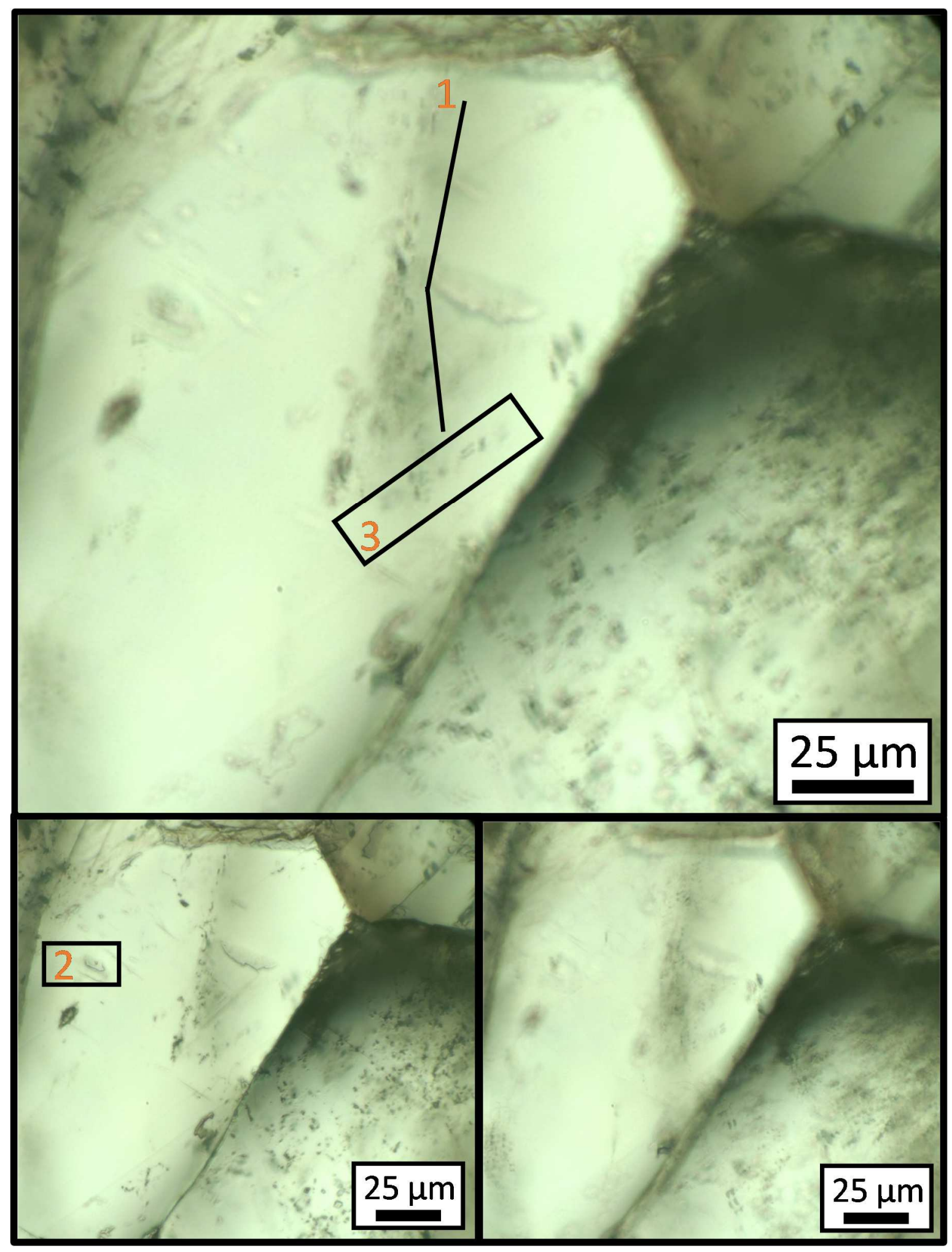

Figure 44. Fluid inclusions present within STC 1. A primary fluid inclusion assemblage (1) is outlined in the top image, along with a secondary fluid inclusion assemblage (3). An IDK inclusion was also observed (2). 


\section{Stable Isotope Analysis}

Carbon and oxygen isotope results for STC 1 are summarized in Table 11 and illustrated in Figure 46. Locations sampled within STC 1 are shown in Figure 45. Carbon and oxygen isotope values within the host rock do not appear to vary much, regardless of proximity to the calcite vein. Carbon isotope values within the blocky calcite do not differ from those of the host rock; however, oxygen isotope values within the blocky calcite are slightly lower than that of the host rock.

\begin{tabular}{|l|c|c|}
\hline \multicolumn{3}{|c|}{ STC 1 (J5, Vallcarga Sequence) } \\
\hline SAMPLE LOCATION & $\delta^{18} \mathrm{O}(\%)$ VPDB & $\delta^{13} \mathrm{C}(\% \circ)$ VPDB \\
\hline Blocky Calcite (Vein) & -2.8 & 3.2 \\
\hline Host 1 (Adjacent to vein) & -2.4 & 3.0 \\
\hline Host 2 & -2.4 & 3.1 \\
\hline Host 3 & -2.3 & 2.9 \\
\hline
\end{tabular}

Table 11. Isotope data for STC 1.

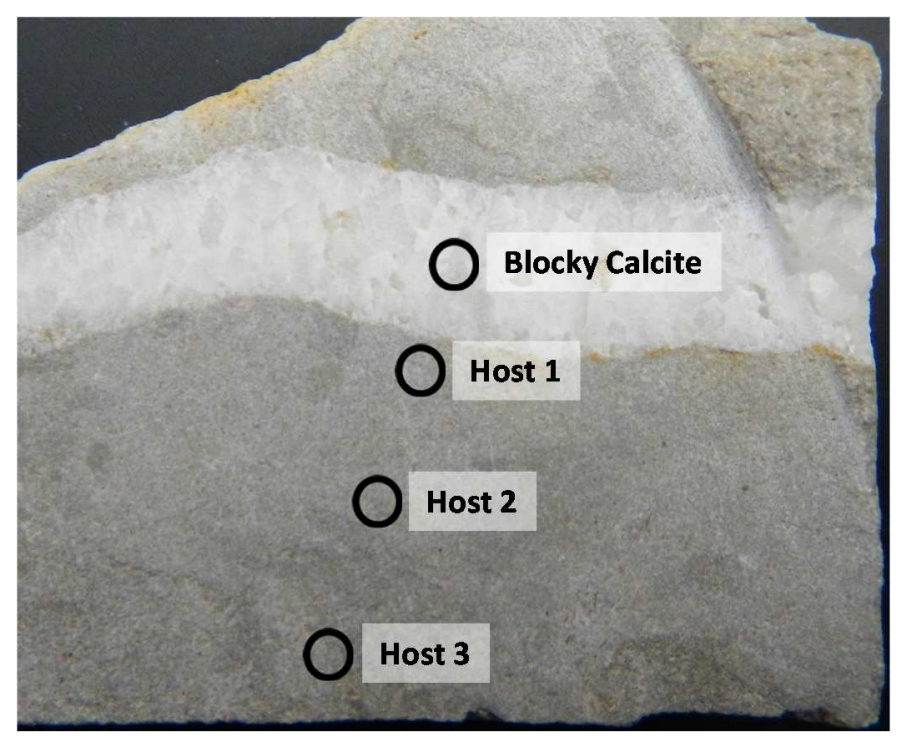

Figure 45. Schematic image showing locations sampled for isotope analyses for STC 1. 


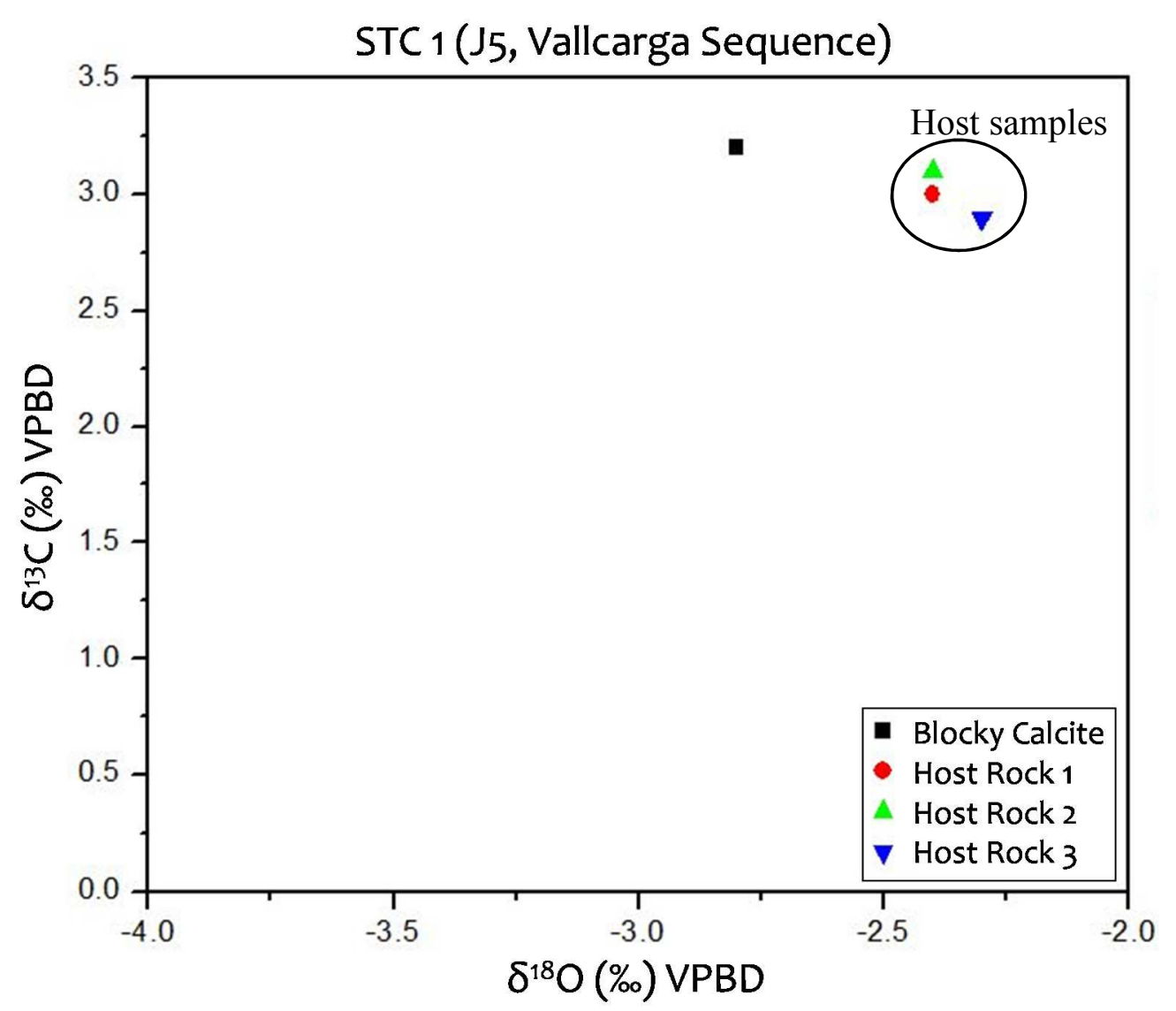

Figure 46. Plot of $\delta^{18} \mathrm{O}$ vs. $\delta^{13} \mathrm{C}$ isotope data for STC 1 . Values for both $\delta^{18} \mathrm{O}$ and $\delta^{13} \mathrm{C}$ are reported with respect to VPDB in per mil (\%).

\section{Interpretations \& Discussion}

The goal of this study was to use petrographic and stable isotope analyses of the five fracture sets included in this study to determine if their characteristics broadly correlate to the groupings of those fracture sets defined by Tavani et al. (2011) or Shackleton et al. (2011). Multiple generations of cements were observed in all five samples analyzed. The veins sampled from the $\mathrm{J} 1$ and $\mathrm{J} 2$ sets exhibit characteristically similar cements and a similar trend in isotope data between the cements and their host rocks. Samples of the J3, J4 and J5 sets differ from the $\mathrm{J} 1$ and $\mathrm{J} 2$ sets characteristically, but exhibit similar cement characteristics in comparison to each other; however, only two of these three samples (J3 and J4) exhibit the same general isotope 
trend. A summary plot of the isotope data for all five samples, highlighting the host rock versus the cement results, is shown in Figure 47.

There is a distinct similarity in the petrography of the vein cements observed in STC 12A (J1? set) and STC 6 (J2 set). This similarity could indicate that the same (or similar) fluids were present at the time of formation for both joints and/or the $\mathrm{J} 1 / \mathrm{J} 2$ sets were under similar pressure/temperature conditions at the time of formation. Although it is uncertain whether STC $12 \mathrm{~A}$ is specifically representing the $\mathrm{J} 1$ or $\mathrm{J} 3$ set of veins due to lack of cross-cutting relationships with the $\mathrm{J} 2$ set in the field, the observation of STC 12A being cross-cut by the vein STC 12B was sampled from indicates that STC $12 \mathrm{~A}$ is at least older than STC 12B, and could potentially be representative of the $\mathrm{J} 1$ set. If STC $12 \mathrm{~A}$ does in fact represent the $\mathrm{J} 1 \mathrm{set}$, the similarity between vein cements of STC 12A and STC 6 would support the interpretations of both Shackleton et al. (2011) and Tavani et al. (2011) that the $\mathrm{J} 1$ and $\mathrm{J} 2$ sets formed prior to the folding of the anticline. It should be noted, however, that the similarity between cements does not favor one interpretation over the other. The interpreted grouping of STC 12A (J1?) and STC 6 (J2) cements together would also indicate a change in the cement-forming fluids and/or conditions between the formation of the $\mathrm{J} 1$ and $\mathrm{J} 2$ sets and the formation of the $\mathrm{J} 3$ set. STC 12B (J3) does not exhibit the fibrous to elongate blocky calcite cements that comprise a large part of the STC 12A (J1?) and STC 6 (J2) veins.

STC 6 (J2) and STC 12A (J1?) also exhibit a similar trend in isotopic composition changes from host rock to cements (see Fig. 47). The older cements of the J1 sample exhibited very similar $\delta^{13} \mathrm{C}$ values in comparison to the host rock, suggesting the host rock was the source of the carbon and that the fracture network was restricted. However, the youngest cement in the $\mathrm{J} 1$ sample was ${ }^{13} \mathrm{C}$ deficient in comparison to the host rock, suggesting the fracture network 
became more open to allow an outside source of carbon to pass through. The cement in the J2 set also exhibited the same deficiency in carbon that was observed in the J1 set. Thus for both of these samples, the youngest cement is deficient in carbon (and also oxygen) in comparison to the host rocks. Although these two samples do not exhibit similar isotopic compositions of their cements, the same trend is observed in both and suggests that the fluids within each fracture set experienced a similar change. The fact that these two samples exhibit different isotopic compositions is potentially due to the influence of the host rock compositions (Sant Corneli sequence for STC 12A and Vallcarga sequence for STC 6). However, another possibility for differing isotopic compositions between the $\mathrm{J} 1$ and $\mathrm{J} 2$ sets could be due to the $\mathrm{J} 1$ set sitting lower in the stratigraphic section and might have experienced more fluid circulation due to the greater number of faults in the Sant Corneli sequence versus the Vallcarga sequence, which is less faulted. 


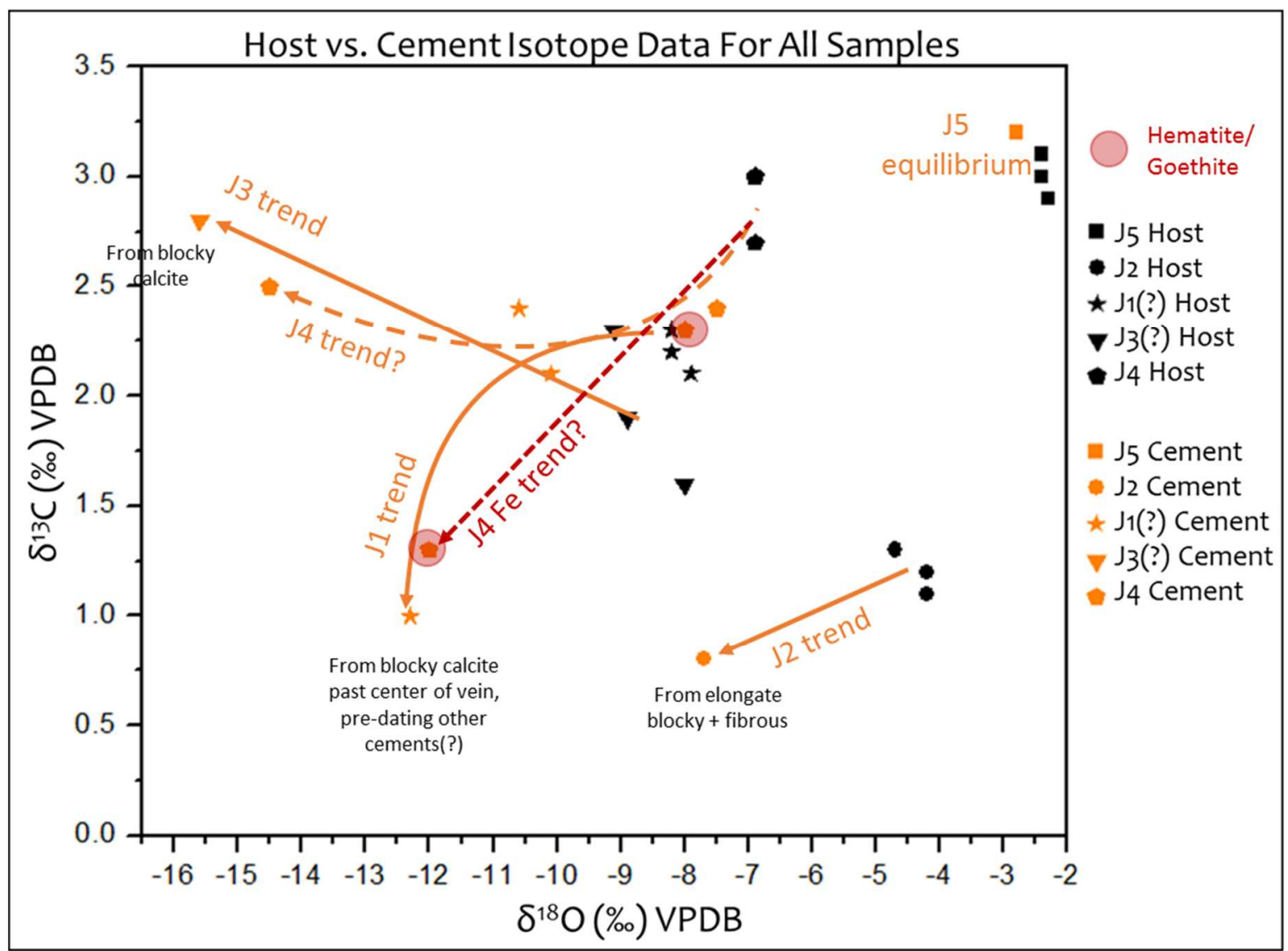

Figure 47. Isotope data for all samples, highlighting the difference between the cement compositions (orange) and the host rock compositions (black). The trends for each sample are illustrated by the lines with arrows. Hematite and goethite samples are highlighted in red.

Samples STC 12B (J3?), STC 13 (J4) and STC 1 (J5) exhibit similar calcite cement morphologies. All three samples consist of drusy calcite, small blocky calcite, and large blocky calcite. This similarity in cement morphologies suggests that these veins formed under similar conditions. However, STC 13 (J4) is also characterized by significant goethite and hematite cements adjacent to the calcite cements filling the vein whereas STC 1 (J5) exhibits a minimal amount of hematite staining and STC 12B (J3?) shows no iron oxides present at all. It is difficult to determine the timing of the iron oxides present in the J4 and J5 samples; however, because they are only observed in the host rocks of the youngest joint sets and not found within the vein 
cements, it is possible that iron oxide staining is due to weathering of younger terrestrial deposits. A possible source for the iron oxides observed in these samples are the Garumnian terrestrial red beds that overly the Aren group around the Sant Corneli anticline.

Vein cement from STC 12B (J3?) exhibited slightly enriched $\delta^{13} \mathrm{C}$ values in comparison to its adjacent host rock. Vein cement from STC 13 (J4) also showed a small change in $\delta^{13} \mathrm{C}$, although, unlike the $\mathrm{J} 3$ sample, the cement is slightly depleted in comparison to the host rock values. This small difference in ${ }^{13} \mathrm{C}$ values between the host rock and vein cement is likely due to the slight presence of an outside source of carbon, indicating an open fluid network or possibly that there was a change occurring from an open to closed network. The J3 and J4 samples both exhibited a large depletion in $\delta^{18} \mathrm{O}$ values. The significant depletion in $\delta^{18} \mathrm{O}$ between cement and host rock for both $\mathrm{J} 3$ and $\mathrm{J} 4$ samples (compared to less depletion in $\delta^{18} \mathrm{O}$ observed with the $\mathrm{J} 1$ and $\mathrm{J} 2$ samples) suggests the fluids were warmer, that the rate of precipitation increased, or that there was a change in the type of fluid.

The differences observed between the $\mathrm{J} 3$ and $\mathrm{J} 4$ samples and the $\mathrm{J} 1$ and $\mathrm{J} 2$ samples do not appear to support or refute the interpretations of Shackleton et al. (2011) that the J3 and J4 sets were formed during folding, while the $\mathrm{J} 1$ and $\mathrm{J} 2$ sets were formed prior to folding. Shackleton et al. (2011) suggested the $\mathrm{J} 1$ and $\mathrm{J} 3$ joints formed due to similar mechanisms but not necessarily under similar fluid conditions while the $\mathrm{J} 2$ set formed from a completely separate mechanism. However, the petrographic and fluid inclusion data support the interpretation that the J1 and J3 sets diverge regarding the origin of their fluids, an observation that is verified by the isopic data. The evidence supporting the idea that the $\mathrm{J} 1$ and $\mathrm{J} 3$ sets do diverge from each other also verifies the timing of these two sets based on the vague cross-cutting relationships observed in the field. Tavani et al. (2011) interpreted the J1, J3 and J4 sets to have formed during pre-folding 
extension (essentially during a "rift stage"); if this were the case, there would likely be very few or very small differences observed between each joint set and that is not what has been observed in the data for these samples.

Isotope data for STC 1 (J5) indicated very little change in oxygen or carbon isotopes between the host rock and vein cement. This lack of change in $\delta^{13} \mathrm{C}$ values suggests that the fluids the cements precipitated from were close to or in equilibrium with the host rock. This indicates that the source of the carbon in the cements could be the host rocks, and that the fracture network was possibly a closed system with respect to subsurface fluid networks. The lack of variation in $\delta^{18} \mathrm{O}$ values suggests that the fluids may have been cooler or that the rate of calcite precipitation decreased, or that there was another change in the type of fluid present, between the formation of the cements in the $\mathrm{J} 3$ and $\mathrm{J} 4$ sets and this $\mathrm{J} 5$ set. The distinct differences observed between the J5 set and the J3 and J4 sets could likely be the result of different stages of folding during the formation of the Sant Corneli anticline, which likely supports both interpretations presented by Tavani et al. (2011) and Shackleton et al. (2011) that the J5 set was formed during a folding stage.

Late quartz cement has also been observed in samples STC 12A (J1), STC 12B (J3) and STC 13 (J4). Although STC 12B (J3?) and STC 13 (J4) exhibit similar calcite cement morphologies in comparison to each other, STC 12A (J1) does not. However, all three samples were taken from the Sant Corneli sequence, which is composed of platform carbonates and calcarenites. Because the late quartz cement is not seen in the samples from the overlying stratigraphy, it is likely that later fluids that resulted in the quartz cement was restricted to the Sant Corneli sequence. The host rock in samples STC 12A (J1) and STC 12B (J3?) exhibit many quartz grains, and the host rock of sample STC 13 (J4) also exhibits quartz grains throughout. 
Therefore, the most likely source for the later quartz-rich fluids are the calcarenites within the Sant Corneli sequence, as they contain a significant amount of quartz grains.

Primary and secondary/pseudosecondary fluid inclusion assemblages and IDK inclusions were observed in calcite cements within each of the five samples analyzed. The primary inclusions observed represent the parent fluids that formed the calcite cement, while the secondary/pseudosecondary inclusions indicate later microfracture events. The lack of any fluorescence in the primary inclusions in any of the samples indicates that there were no hydrocarbons or microorganisms trapped within the inclusions. Although homogenization and freezing/melting runs were not possible for inclusions within for four samples, the attempt at acquiring homogenization temperatures from inclusions within the calcite cement of STC 12B (J3?) did yield some information. The vapor bubbles present in the inclusions became too small to see at approximately $50^{\circ} \mathrm{C}$ during homogenization runs and the exact temperatures at which those vapor bubbles homogenized was not determinable with any level of confidence. However, it can be inferred that these fluids were likely trapped relatively close to the surface and at relatively low temperatures because the vapor bubbles became too small to observe at approximately $50^{\circ} \mathrm{C}$.

Isotope data was used with the equation from Friedman \& O’Neil (1977) in an attempt to estimate the parent fluid temperatures at the time of cement precipitation. The carbon and oxygen data were used as separate proxies. The temperatures calculated using the oxygen isotope data were calculated assuming a parent fluid oxygen composition of $-30.0 \%$ VPDB (an approximation for marine waters), and are shown in Table 12 below. The calculated temperatures using the oxygen isotope data yield some realistic potential parent fluid temperatures, assuming the parent fluid compositions for each sample were approximately that 
of modern marine waters (-30.0\% VPDB). However, that assumption is not accurate for sample STC 1, as the calculated temperature was extremely high $\left(783.6^{\circ} \mathrm{C}\right)$. It should also be noted that the calculated temperature for sample STC $12 \mathrm{~B}$ is significantly higher than the estimated homogenization temperature from the fluid inclusions analyzed within that sample $\left(127.9^{\circ} \mathrm{C}\right.$ calculated vs. $\sim 52.0^{\circ} \mathrm{C}$ ), suggesting that the parent fluid oxygen composition was not $-30.0 \%$ o VPDB. Using the same equation from Friedman \& O’Neil (1977) with the temperature estimated from the fluid inclusion homogenization runs, a parent oxygen composition of $-39.0 \%$ VPDB was estimated.

\begin{tabular}{|l|c|c|}
\hline Sample & Vein Cement Composition & Calculated Temperature \\
\hline STC 12A & $-12.3 \%$ VPDB & $52.6^{\circ} \mathrm{C}$ \\
\hline STC 12B & $-15.6 \%$ VPDB & $127.9^{\circ} \mathrm{C}$ \\
\hline STC 6 & $-7.7 \% \circ$ VPDB & $59.2^{\circ} \mathrm{C}$ \\
\hline STC 13 & $-14.5 \% \circ$ VPDB & $115.8^{\circ} \mathrm{C}$ \\
\hline STC 1 & $-2.8 \% \circ$ VPDB & $783.6^{\circ} \mathrm{C}$ \\
\hline
\end{tabular}

Table 12. Parent fluid temperatures calculated using oxygen isotope data from the youngest cements of each sample, assuming a parent fluid composition of $-30 \%$ VPDB.

Carbon isotope data from each sample was used as a separate proxy to estimate a temperature at which the cements precipitated at. The calculated temperatures are shown in Table 13, in which the carbon isotope data from the youngest cement of each sample and the host rock adjacent to the vein were used in the calculations. The calculated temperatures for the J1, J3 and $\mathrm{J} 4$ samples (STC 12A, 12B and 6) are unrealistic due to their negative nature. This suggests that the host rock carbon isotope composition is a poor assumption for the parent fluid carbon isotope composition. The temperatures calculated from the data for the $\mathrm{J} 2$ and $\mathrm{J} 5$ samples are reasonable estimates for parent fluid temperatures at the time of precipitation, although they do 
not match the temperatures calculated using the oxygen isotope data, likely because the carbon isotope composition of the parent fluids is assumed to be that of the host rock in the calculations.

\begin{tabular}{|l|c|c|c|}
\hline Sample & $\begin{array}{c}\text { Vein Cement } \\
\text { Composition }\end{array}$ & $\begin{array}{c}\text { Host Rock } \\
\text { Composition }\end{array}$ & $\begin{array}{c}\text { Calculated } \\
\text { Temperature }\end{array}$ \\
\hline STC $12 \mathrm{~A}$ & $1.0 \%$ VPDB & $2.2 \%$ VPDB & $-13.4^{\circ} \mathrm{C}$ \\
\hline STC $12 B$ & $2.8 \% \circ$ VPDB & $1.6 \%$ VPDB & $31.5^{\circ} \mathrm{C}$ \\
\hline STC 6 & $0.8 \% \circ$ VPDB & $1.3 \%$ VPDB & $-1.7^{\circ} \mathrm{C}$ \\
\hline STC 13 & $2.5 \%$ VPDB & $3.0 \%$ VPDB & $-1.7^{\circ} \mathrm{C}$ \\
\hline STC 1 & $3.2 \% \circ$ VPDB & $3.0 \%$ VPDB & $11.0^{\circ} \mathrm{C}$ \\
\hline
\end{tabular}

Table 13. Parent fluid temperatures at time of cement precipitation, calculated using the carbon isotope compositions of the youngest cement and adjacent host rock for each sample.

\section{Conclusions \& Future Work}

Veins of five distinct joint sets observed at the Sant Corneli anticline were sampled to characterize the fluids that migrated through these joints at the time of their formation and to determine if their characteristics broadly correlate to the groupings of these joint sets interpreted by Tavani et al. (2011) or Shackleton et al. (2011). Thin-section and fluid inclusion petrography, fluid inclusion microthermometry, and isotope analyses were used to determine any similarities or differences between the vein cements of each joint set.

Samples STC 12A(J1?) and STC 6(J2) exhibited similarities in both petrography and isotopic trends. The strong correlation between these two samples supports both interpretations presented by Shackleton et al. (2011) and Tavani et al. (2011), but does not favor one interpretation over the other. These samples both had small blocky and elongate blocky to fibrous calcite cement. They also both exhibited the same isotopic trend in which the youngest cements were depleted in both $\delta^{18} \mathrm{O}$ and $\delta^{13} \mathrm{C}$ in comparison to their respective host rocks. 
The samples representing the $\mathrm{J} 3$ and $\mathrm{J} 4$ sets also showed many similarities with each other, yet distinct differences from the $\mathrm{J} 1$ and $\mathrm{J} 2$ samples. These similarities between the $\mathrm{J} 3$ and J4 samples appear to support the interpretations of Shackleton et al. (2011) that the J3 and J4 sets formed during folding while the $\mathrm{J} 1$ and $\mathrm{J} 2$ sets formed during a prefolding stage as the result of extension and basin margin collapse (J1), and slump faulting (J2). The support for this interpretation is evidenced by the similar cement morphologies of blocky calcite between the two samples. These sets also exhibited similar trends in $\delta^{18} \mathrm{O}$ values that were not observed in the other three samples. The $\delta^{13} \mathrm{C}$ values of the cements of both samples in comparison to their respective host rocks also suggested that the subsurface fluid network was at least partially open, allowing an outside source of carbon for the fluids.

The J5 set likely represents a late stage of folding. Although it exhibited a similar cement morphology to the $\mathrm{J} 3$ and $\mathrm{J} 4$ samples, the isotope results were very different, suggesting there was a change in precipitation rate or fluid temperature, or possibly even fluid composition between the $\mathrm{J} 3$ and $\mathrm{J} 4$ samples and the $\mathrm{J} 5$ set. The observed differences in isotope compositions of the $\mathrm{J} 5$ cement suggests that the fluid network continued to change from an open network to a closed network and likely represents a later stage of folding, in comparison to the J3 and J4 samples.

The presence of the late quartz cement in the samples from the Sant Corneli sequence has been interpreted to be the result of later fluids that became restricted stratigraphically, with the quartz coming locally from the Sant Corneli sequence. This interpretation is supported by the fact that all three samples from the Sant Corneli sequence (STC 12A/J1?, STC 12B/J3?, and STC 13/J4) exhibit late quartz cement. Stratigraphically restricted fluids will also result in different isotopic compositions between the host rock and cements because the fluids are limited in terms 
of what they can react with within the host rock as they try to achieve equilibrium. This late quartz cement was not observed in samples STC 6 and STC 1, which were both sampled from stratigraphy overlying the Sant Corneli sequence.

This project has presented many challenges and left many questions unanswered. However, this project has also provided avenues for further research. The compositions and salinities of the fluids trapped within the primary inclusions observed in each sample are still uncertain. Although carbon and oxygen isotopes can provide an idea as to whether the fluids are meteoric, oceanic or brines, they cannot provide the salinities of the fluids as freezing/melting runs with inclusions can. The temperatures and pressures at which these inclusions were trapped is also still an uncertainty. Working with fluid inclusions in calcite cements is a difficult task due to the double refraction property of calcite as well as the size of the inclusions trapped within calcite. Future fluid inclusion studies should incorporate multiple samples for each joint set to increase the probability of finding usable and visible primary fluid inclusions. Future studies focused on these joint sets should also include more extensive observations for each joint set, and at multiple stratigraphic levels where possible. Independent carbon and oxygen isotope analyses at a more detailed level across each vein might provide more insight into the changes that occurred as the cements precipitated from their parent fluids. Clumped isotope analyses of the vein samples could also provide more insight into the origin of the fluids the veins precipitated from and also the conditions that were present during formation. 


\section{References}

Anastasio, D.J., Bebout, G.E., and Holl, J.E., 2004, Extra-basinal fluid infiltration, mass transfer, and volume strain during folding: insights from the Idaho-Montana thrust belt: American Journal of Science, v. 304, p. 333-369.

Bakker, R.J., 2003, Package FLUIDS 1. Computer programs for analysis of fluid inclusion data and for modeling bulk fluid properties: Chemical Geology, v. 194, p. 3-23.

Beaudoin, N., Bellahsen, N., Lacombe, O., and Emmanuel, L., 2011, Fracture-controlled paleohydrogeology in a basement-cored, fault-related fold: Sheep Mountain Anticline, Wyoming, United States: Geochemistry, Geophysics, Geosystems, v. 12, Q06011, doi:10.1029/2010GC003494.

Berastegui, X., Garcia-Senz, J.M., and Losantos, M., 1990, Tecto-sedimentary evolution of the Organya extensional basin (central south Pyrenean unit, Spain) during the Lower Cretaceous: Bulletin de la Société Géologique de France, v. 6, p. 251-264.

Bond, R.M.G., and McClay, K.R., 1995, Inversion of a Lower Cretaceous extensional basin, south central Pyrenees, Spain: Geological Society of London, Special Publications, v. 88, p. 415-431.

Bons, P.D., 2000, The formation of veins and their microstructures, in Jessell, M.W. and Urai, J.L. eds., Stress, Strain and Structure, A volume in honour of W D Means, Journal of the Virtual Explorer, v. 2.

Bons, P.D., Elburg, M.A., and Gomez-Rivas, E., 2012, A review of the formation of tectonic veins and their microstructures: Journal of Structural Geology, v. 43, p. 33-62.

Clark, I.D., and Fritz, P., 1997, Environmental Isotopes in Hydrogeology: Florida, CRC Press, $331 \mathrm{p}$.

Deramond, J., Souquet, P., Fondecave-Wallez, M.J., and Specht, M., 1993, Relationships between thrust tectonics and sequence stratigraphy surfaces in foredeeps: Model and examples from the Pyrenees (Cretaceous-Eocene, France, Spain): Geological Society of London, Special Publications, v. 71, p. 193-219, doi:10.1144/GSL.SP.1993.071.01.09.

Drzewiecki, P., and Simo, J.A., 2000, Tectonic, eustatic and environmental controls on midCretaceous carbonate platform deposition, south-central Pyrenees, Spain: Sedimentology, v. 47, p. 471-495.

Evans, M.A., 2010, Temporal and spatial changes in deformation conditions during the formation of the Central Appalachian fold-and-thrust belt: Evidence from joints, vein mineral paragenesis, and fluid inclusions, in Tollo, R., Bartholomew, M.J., Hibbard, J., and Karbinos, P. eds., From Rodinia to Pangea: The Lithotectonic Record of the Appalachian Region, Geological Society of America Memoir 206, p. 477-552. 
Evans, M.A., and Battles, D.A., 1999, Fluid inclusion and stable isotope analyses of veins from the central Appalachian Valley and Ridge province: Implications for regional synorogenic hydrologic structure and fluid migration: GSA Bulletin, v. 111, 1841-1860.

Evans, M.A., Bebout, G.E., and Brown, C.H., 2012, Changing fluid conditions during folding: An example from the central Appalachians: Tectonophysics, v. 576-577, p. 99-115, doi:10.1016/j.tecto.2012.03.002.

Evans, M.A., DeLisle, A., Leo, J., Lafonte, C.J., 2014, Deformation conditions for fracturing in the Middle Devonian sequence of the central Appalachians during the Late Paleozoic Alleghenian orogeny: AAPG Bulletin, v. 98, p. 2263-2299.

Evans, M.A., and Fischer, M.P., 2012, On the distribution of fluids in folds: A review of controlling factors and processes: Journal of Structural Geology, v. 44, p. 2-24.

Ferket, H., Swennen, R., Ortuño-Arzate, S., Cacas, M.C., and Roure, F., 2004, Vein formation in Cretaceous carbonates in the Laramide foreland fold and thrust belt of eastern Mexico in Swennen, R., Roure, F., and Granath, J.W. eds., Deformation, fluid flow, and reservoir appraisal in foreland fold and thrust belts: AAPG Hedberg Series, no. 1, p. 133-156.

Fischer, M.P., Higuera-Diaz, I.C., Evans, M.A., Perry, E.C., and Lefticariu, L., 2009, Fracturecontrolled paleohydrology in a map-scale detachment fold: Insights from the analysis of fluid inclusions in calcite and quartz veins: Journal of Structural Geology, v. 31, p. 14901510, doi:10.1016/j.jsg.2009.09.004.

Fitz-Diaz, E., Hudleston, P., Siebenaller, L., Kirschner, D., Camprubí, A., Tolson, G., and Puig, T.P., 2011, Insights into fluid flow and water-rock interaction during deformation of carbonate sequences in the Mexican fold-thrust belt: Journal of Structural Geology, v. 33, p. 1237-1253, doi:10.1016/jsg.2011.05.009.

Friedman, I., and O'Neil, J.R., 1977, Compilations of stable isotope fractionation factors of geochemical interest in Fleicher, M. eds., Data of Geochemistry: U.S.G.S. Professional Paper, no. KK, p. KK1-KK12.

Gao, G., Elmore, R.D., and Land, L.S., 1992, Geochemical constraints on the origin of calcite veins and associated limestone alteration, Ordovician Viola Group, Arbuckle Mountains, Oklahoma, U.S.A.: Chemical Geology, v. 98, p. 257-269.

Garcia-Senz, J., 2002, Cuencas extensivas del Cretácico Inferior en los Pirineos centrales: formación y subsecuente inversion [Doctoral thesis]: Barcelona, Universitat de Barcelona.

Goldstein, R.H., and Reynolds, T.J., 1994, Systematics in fluid inclusions in diagenetic minerals: SEPM Short Course 31, 199p.

Guillaume, B., Dhont, D., and Brusset, S., 2008, Three-dimensional geologic imaging and tectonic control on stratigraphic architecture: Upper Cretaceous of the Tremp Basin 
(south-central Pyrenees, Spain): AAPG Bulletin, v. 92, p. 249-269, doi:10.1306/10110706089.

Hennings, P., Allwardt, P., Paul, P., Zahm, C., Reid, R., Alley, H., Kirschner, R., Lee, B., and Hough, E., 2012, Relationship between fractures, fault zones, stress, and reservoir productivity in the Suban gas field, Sumatra, Indonesia: AAPG Bulletin, v. 96, p. 753772.

Hilgers, C., and Urai, J.L., 2002, Microstructural observations on natural syntectonic fibrous veins: Implications for the growth process: Tectonophysics, v. 352, p. 257-274.

Holland, R.A.G., Bray, C.J., Spooner, E.T.C., 1978, A method for preparing doubly polished thin sections suitable for microthermometric examination of fluid inclusions: Mineralogical Magazine, v. 42, p. 407-408.

Labraña de Miguel, G., 2004, Evolució de fluids en un anticlinal: estudi pilot en l'anticlinal de Sant Corneli, Pallars Jusà, Llieda [M.S. thesis]: Barcelona, Universitat de Barcelona, 114 p.

Lee, Y.J., Wiltschko, D.V., Grossman, E.L., Morse, J.W., and Lamb, W.M., 1997, Sequential vein growth with fault displacement: An example from the Austin Chalk Formation, Texas: Journal of Geophysical Research, v. 102, p. 22,611-22,628.

Lefticariu, L., Perry, E.C., Fischer, M.P., and Banner, J.L., 2005, Evolution of fluid compartmentalization in a detachment fold complex: Geology, v. 33, p. 69-72, doi:10.1130/G20592.1.

McClay, K., Muñoz, J.A., and Garcia-Senz, J., 2004, Extensional salt tectonics in a contractional orogeny: A newly identified tectonic event in the Spanish Pyrenees: Geology, v. 32, p. 737-740, doi:10.1130/G20565.1.

Mencos, J., Muñoz, J.A., and Hardy, S., 2010, 3D kinematics of the Sant Corneli anticline: Insights from structural reconstruction and forward modeling: Trabajos de Geología, Universidad de Oviedo, v. 30, p. 75-80.

Mencos, J., Muñoz, J.A., and Hardy, S., 2011, Three-dimensional geometry and forward numerical modeling of the Sant Corneli Anticline (Southern Pyrenees, Spain) in McClay, K., Shaw, J.H., and Suppe, J. eds., Thrust fault-related folding: AAPG Memoir 94, p. 283-300, doi:10.1306/13251342M943434.

Munz, I.A., 2001, Petroleum inclusions in sedimentary basins: Systematics, analytical methods and applications: Lithos, v. 55, p. 195-212.

Nagtegaal, P.J.C., Van Vliet, A., and Brouwer, J., 1983, Syntectonic coastal offlap and concurrent turbidite deposition: The Upper Cretaceous Aren Sandstone in the southcentral Pyrenees, Spain: Sedimentary Geology, v. 34, p. 185-218.

O’Neil, J.R., Clayton, R.N., and Mayeda, T.K., 1969, Oxygen isotope fractionation in divalent metal carbonates: Journal of Chemical Physics, v. 51, no. 12, p. 5547-5558. 
Ohmoto, H., 1972, Systematics of sulfur and carbon isotopes in hydrothermal ore deposits: Economic Geology, v. 67, p. 551-578.

Railsback, B., 2006, Some fundamentals of mineralogy and geochemistry: http://www.gly.uga.edu/railsback/FundamentalsIndex.html\#Carbonates (accessed March 2016).

Shackleton, J.R., Cooke, M.L., Vergés, J., and Simó, T., 2011, Temporal constraints on fracturing associated with fault-related folding at Sant Corneli anticline, Spanish Pyrenees: Journal of Structural Geology, v. 33, p. 5-19, doi:10.1016/j.jsg.2010.11.003.

Simó, A., Puigdefabregas, C., and Gili, E., 1985, Transition from shelf to basin on an active slope, upper Cretaceous Tremp area, southern Pyrenees in Mila, M.D., and Rosell, J. eds., International Association of Sedimentologists, Sixth European Regional Meeting: Excursion Guidebook, p. 63-108.

Simó, A., 1989, Upper Cretaceous platform-to-basin depositional-sequence development, Tremp Basin, south-central Pyrenees, Spain in Crevello, P.D., Wilson, J.L., Sarg, J.F., and Read, J.F. eds., Controls on carbonate platform and basin development: SEPM Special Publication 44, p. 365-378.

Srivastava, D.C., and Engelder, T., 1990, Crack-propagation sequence and pore-fluid conditions during fault-bend folding in the Appalachian Valley and Ridge, central Pennsylvania: GSA Bulletin, v. 102, p. 116-128.

Tavani, S., Mencos, J., Bausà, J., and Muñoz, J.A., 2011, The fracture pattern of the Sant Corneli Bóixols oblique inversion anticline (Spanish Pyrenees): Journal of Structural Geology, v. 33, p. 1662-1680, doi:10.1016/j.jsg.2011.08.007.

Touret, J.L.R., 2001, Fluids in metamorphic rocks: Lithos, v. 55, p. 1-25.

Travé, A., Calvet, F., Sans, M., Vergés, J., and Thirlwall, M., 2000, Fluid history related to the Alpine compression at the margin of the south-Pyrenean Foreland basin: the El Guix anticline: Tectonophysics, v. 321, p. 73-102.

Travé, A., Labaume, P., \& Vergés, J., 2007, Fluid systems in foreland fold-and-thrust belts: an overview from the southern Pyrenees in Lacombe, O., Lavé, J., Roure, F.M., and Verges, J., eds., Thrust belts and foreland basins: New York, NY, Springer Berlin Heidelberg, p. 93-115.

Wilkinson, J.J., 2001, Fluid inclusions in hydrothermal ore deposits: Lithos, v. 55, p. 229-272. 


\section{Appendices}

\subsection{Petrographic observations of samples in thin section}

\begin{tabular}{|c|c|c|c|}
\hline Sample & Orientation & Joint Set & Description \\
\hline STC 1 & $235 / 65 \mathrm{NW}$ & J5 & $\begin{array}{l}\text { Vein is } \sim 0.5 \mathrm{~cm} \text { thick; isopachous small blocky calcite cement adjacent to host rock as } 1 \mathrm{st} \\
\text { generation; } 2^{\text {nd }} \text { generation cement is isopachous large blocky to elongate calcite in center } \\
\text { of vein; small }(\sim 0.25-1.5 \mathrm{~mm}) \text { vugs in the center of } 2^{\text {nd }} \text { generation calcite; vein appears to } \\
\text { be syntaxial with no evidence of shear during growth; most crystals appear to be heavily } \\
\text { twinned - clearness of crystals is dependent upon amount of twinning; some iron-oxide } \\
\text { staining is present at the wall rock-vein interface. }\end{array}$ \\
\hline STC 2 & $\begin{array}{l}\text { Bed-strike } \\
\text { parallel }\end{array}$ & J4 & $\begin{array}{l}\text { Vein is } \sim 0.2 \mathrm{~cm} \text { thick; appears to be two generations of cement - isopachous small blocky } \\
\text { calcite adjacent to the host, followed by a } 2^{\text {nd }} \text { generation of isopachous large to elongate } \\
\text { blocky calcite; vein appears to be syntaxial; crystals are curved - likely due to shear; } \\
\text { calcite is heavily twinned and milky white in color; vein appears to cut through a } \\
\text { deformation band - the deformation band is offset on either side of the vein - supports } \\
\text { shear during vein formation; there appears to be some organics trapped in the crystals } \\
\text { where the vein cuts deformation band. }\end{array}$ \\
\hline STC 3 & $255 / 60 \mathrm{~N}$ & J5 & $\begin{array}{l}\text { Vein is } \sim 0.25-0.5 \mathrm{~cm} \text { thick; there are two generations of cement }-1^{\text {st }} \text { generation of thin } \\
\text { isopachous drusy to very small blocky calcite followed by isopachous large blocky } \\
\text { calcite; calcite is mostly clear with some iron oxide staining; calcite crystals are heavily } \\
\text { twinned; thinner vein } \sim 0.1-0.2 \mathrm{~cm} \text { with drusy calcite adjacent to wall rock, followed by } \\
\text { fibrous calcite in center; calcite is milky white; vein fill in all fractures appear to be } \\
\text { separate generations. }\end{array}$ \\
\hline STC 4 & $340 / 90$ & $\mathrm{~J} 2$ & $\begin{array}{l}\text { Vein is } \sim 0.5 \mathrm{~cm} \text { wide; } 1^{\text {st }} \text { generation cement is isopachous small blocky calcite followed } \\
\text { by } 2^{\text {nd }} \text { generation of elongate blocky calcite and few rare quartz crystals; quartz crystals } \\
\text { appear to be from later fluids passing through; calcite xls are clear, appear to be } \\
\text { syntaxial. }\end{array}$ \\
\hline STC 5 & $345 / 85 \mathrm{E}$ & $\mathrm{J} 2$ & $\begin{array}{l}\text { Vein is } \sim 2.5-3 \mathrm{~cm} \text { wide; appears to be one generation of isopachous large to elongate } \\
\text { blocky calcite w/ iron oxides mixed in; most crystals are heavily twinned; majority of } \\
\text { crystals are milky with few clear crystals; some "vugs" - likely due to dissolution. }\end{array}$ \\
\hline STC 6 & $340 / 90$ & $\mathrm{~J} 2$ & $\begin{array}{l}\text { Vein is } \sim 1-2 \mathrm{~cm} \text { wide; } 1^{\text {st }} \text { generation of curved fibrous calcite - indicates shear during } \\
\text { initial formation; a } 2^{\text {nd }} \text { generation of isopachous large to elongate blocky calcite appears } \\
\text { parallel to the } 1^{\text {st }} \text { generation fibrous calcite; some iron oxides are present throughout; } \\
\text { most crystals are milky. }\end{array}$ \\
\hline STC 7 & $130 / 82 \mathrm{SW}$ & J4 & $\begin{array}{l}\text { Vein is } \sim 0.25 \mathrm{~cm} \text { wide; } 1^{\text {st }} \text { generation of cement is an isopachous small blocky adjacent to } \\
\text { the wall rock; } 2^{\text {nd }} \text { generation is an isopachous large blocky calcite at the center of the } \\
\text { vein; first gen possibly quartz? - no cleavage or twinning visible, lower relief than second } \\
\text { gen, possible conchoidal fracture, not pleochroic, low birefringence; } 2^{\text {nd }} \text { gen. cement has } \\
\text { distinct cleavage visible and some crystals exhibit twinning. }\end{array}$ \\
\hline STC 8 & $300 / 75 \mathrm{~N}$ & $\mathrm{~J} 4$ & $\begin{array}{l}\text { Two generations of calcite cement }-1^{\text {st }} \text { generation is isopachous small blocky calcite } \\
\text { adjacent to host rock but not consistent, } 2^{\text {nd }} \text { generation is isopachous large blocky cement } \\
\text { in the center of the vein; possible } 3^{\text {rd }} \text { generation of isopachous small blocky calcite with } \\
\text { iron oxides down the center of the vein - a second fracture opening event? }\end{array}$ \\
\hline STC 9 & $\begin{array}{l}\sim 300 \text { (fault } \\
\text { w/roll over) }\end{array}$ & J4 & $\begin{array}{l}\text { Fault breccia sample; } 2 \text { possible generations of cement }-1^{\text {st }} \text { generation appears to be a } \\
\text { thin layer of isopachous small blocky cement adjacent to wall rock fragments (possibly } \\
\text { quartz but difficult to determine), } 2^{\text {nd }} \text { generation is isopachous large blocky calcite filling } \\
\text { in; } 1^{\text {st }} \text { generation of cement exhibits no twinning or cleavage, appear to have lower relief } \\
\text { than surrounding crystals and possible conchoidal fracture, no pleochroisim - possibly } \\
\text { quartz. }\end{array}$ \\
\hline
\end{tabular}




\begin{tabular}{|c|c|c|c|}
\hline $\begin{array}{l}\text { STC } \\
10 \mathrm{~A}\end{array}$ & $168 / 83 \mathrm{~W}$ & $\mathrm{~J} 1 / \mathrm{J} 3$ & $\begin{array}{l}\text { Vein } \sim 0.8 \mathrm{~cm} \text { wide; } 1^{\text {st }} \text { generation of cement is a thin layer of isopachous small blocky } \\
\text { calcite adjacent to wall rock; } 2^{\text {nd }} \text { generation of cement is isopachous large blocky calcite; } \\
\text { crystals are cloudy and exhibit cleavage } \& \text { some twinning; some organics and/or iron } \\
\text { oxides are present; possible vug in host rock adjacent to vein filled by chalcedony or } \\
\text { radial calcite cement - distinct feathery texture and undulose extinction, potentially a } \\
\text { replacement cement within a skeletal grain; sample also contains smaller en-echelon to } \\
\text { perpendicular veins }(\sim 0.1-0.2 \mathrm{~cm} \text { thick) filled with isopachous small blocky calcite - } \\
\text { likely same as } 1^{\text {st }} \text { generation. }\end{array}$ \\
\hline $\begin{array}{l}\text { STC } \\
10 B\end{array}$ & $115 / 54 \mathrm{~W}$ & $\mathrm{~J} 4$ & $\begin{array}{l}\text { Fault breccia sample; appears to be } 1 \text { generation of isopachous small blocky calcite } \\
\text { cement; crystals are very cloudy with significant iron oxide staining in some parts and } \\
\text { some possible organics present; calcite with iron oxide staining is much clearer - possibly } \\
\text { a } 2^{\text {nd }} \text { generation; very small fracture with iron oxide staining cuts main vein of cloudy } \\
\text { calcite, filled in with clear calcite and iron oxides - same as } 2^{\text {nd }} \text { generation. }\end{array}$ \\
\hline $\begin{array}{l}\text { STC } \\
11 \mathrm{~A}\end{array}$ & $050 / 35 \mathrm{~S}$ & J5 & $\begin{array}{l}\text { Vein is } \sim 2.5 \mathrm{~cm} \text { wide; multiple gens of cement with possibly multiple opening events; } \\
\text { one opening event appears to have } 2 \text { generations of cement - drusy calcite surrounding } \\
\text { isopachous small blocky calcite; another possible opening event with } 2 \text { generations of } \\
\text { cement - isopachous small blocky calcite surrounded by isopachous large blocky calcite; } \\
\text { possibly brecciated - very complex sample; most calcite moderately to very cloudy, but } \\
\text { some crystals are very clear. }\end{array}$ \\
\hline $\begin{array}{l}\text { STC } \\
11 B\end{array}$ & $145 / 20 \mathrm{~W}$ & $\mathrm{~J} 1 / \mathrm{J} 3$ & $\begin{array}{l}\text { Vein } \sim 0.5 \mathrm{~cm} \text { wide; at least } 2 \text { generations }-1^{\text {st }} \text { generation is isopachous large blocky } \\
\text { calcite associated with host rock; } 2^{\text {nd }} \text { generation of elongate blocky calcite adjacent to } \\
\text { host rock, crystals are cloudy; } 3^{\text {rd }} \text { generation of clear elongate blocky calcite cement; } \\
\text { distinct cleavage seen; possible organics present. }\end{array}$ \\
\hline $\begin{array}{l}\text { STC } \\
11 C\end{array}$ & $? ? ?$ & $? ? ?$ & $\begin{array}{l}\text { Vein is several centimeters wide; multiple generations of cement that cross-cut each } \\
\text { other; } 1^{\text {st }} \text { generation is drusy calcite, followed by } 2^{\text {nd }} \text { generation of isopachous large } \\
\text { blocky calcite with bits of host rock trapped, crystals are cloudy \& heavily twinned; } 3^{\text {rd }} \\
\text { generation is clear isopachous large blocky calcite that cross-cuts and offsets host rock } \\
\text { w/in the } 2^{\text {nd }} \text { generation cement; separate generation of possible chalcedony or radial } \\
\text { calcite - undulose extinction, radial feathery texture, no evidence to determine whether it } \\
\text { occurred before or after } 3^{\text {rd }} \text { generation of cement. }\end{array}$ \\
\hline $\begin{array}{l}\text { STC } \\
12 \mathrm{~A}\end{array}$ & $149 / 76 \mathrm{SW}$ & J1(?) & $\begin{array}{l}\text { Vein is } \sim 2-3 \mathrm{~cm} \text { wide; } 1^{\text {st }} \text { generation of cement is drusy followed by } 2^{\text {nd }} \text { generation of } \\
\text { curved elongate blocky calcite adjacent to host rock; } 3^{\text {rd }} \text { generation of cement is } \\
\text { isopachous small blocky calcite; } 2^{\text {nd }} \text { generation cement is cloudy and contains some host } \\
\text { rock trapped; very thin }(\sim 1-2 \mathrm{~mm} \text { wide }) \text { fractures seen in host rock parallel to main vein } \\
\text { filled with isopachous small blocky calcite; late stage of quartz appears to fill in areas of } \\
\text { calcite that underwent dissolution }- \text { seen in both } 2^{\text {nd }} \text { and } 3^{\text {rd }} \text { generations. }\end{array}$ \\
\hline $\begin{array}{l}\text { STC } \\
12 B\end{array}$ & $163 / 63 \mathrm{SW}$ & $\mathrm{J} 3(?)$ & $\begin{array}{l}\text { Vein } \sim 0.5 \mathrm{~cm} \text { thick; } 1^{\text {st }} \text { generation of cement is drusy followed by } 2^{\text {nd }} \text { generation of } \\
\text { isopachous small blocky calcite adjacent to host rock and in small vein that cuts through } \\
\text { host rock perpendicular to main vein; } 3^{\text {rd }} \text { generation of cement is isopachous large blocky } \\
\text { calcite with some euhedral crystals; few quartz crystals are seen along the top of the vein } \\
\text { in the } 3^{\text {rd }} \text { generation cement - likely a later stage of cement filling in areas of dissolution. }\end{array}$ \\
\hline STC 13 & $115 / 75 \mathrm{~S}$ & $\mathrm{~J} 4$ & $\begin{array}{l}\text { Vein } \sim 2-3 \mathrm{~cm} \text { thick; } 2 \text { distinct bands of iron oxides within host rock - bright orange } \\
\text { goethite followed by dark blood red hematite adjacent to the vein; } 1^{\text {st }} \text { generation of } \\
\text { isopachous small blocky calcite cement adjacent to the hematite cement in the host rock; } \\
2^{\text {nd }} \text { generation of isopachous large blocky calcite with some semi-euhedral crystals; } \\
\text { possible late stage quartz present within the } 2^{\text {nd }} \text { generation of calcite cement. }\end{array}$ \\
\hline STC 14 & $155 / 80 \mathrm{SW}$ & $\mathrm{J} 1 / \mathrm{J} 3$ & $\begin{array}{l}\text { Vein } \sim 0.5 \mathrm{~cm} \text { thick; } 1^{\text {st }} \text { generation of cement is isopachous small blocky calcite adjacent } \\
\text { to host rock; } 2^{\text {nd }} \text { generation is isopachous large blocky calcite in the center of the vein; } \\
\text { smaller vein that branches off main vein also has } 3 \text { small en-echelon veins related, all } \\
\text { filled with elongate blocky calcite cement - possible } 3^{\text {rd }} \text { generation of cement but } \\
\text { unclear. }\end{array}$ \\
\hline
\end{tabular}




\subsection{Isotope data for all samples}

\begin{tabular}{|l|l|c|c|c|}
\hline Sample ID & Stratigraphic Unit & Joint Set & $\mathbf{\delta}^{\mathbf{1 3}} \mathbf{C ~ ( \% o ) ~}$ & $\left.\boldsymbol{\delta}^{\mathbf{1 8}} \mathbf{O} \mathbf{( \% o}\right)$ \\
\hline STC 12A - Blocky Calcite & Sant Corneli Sequence & J1? & 1.0 & -12.3 \\
\hline STC 12A - Elongate Blocky (center) & Sant Corneli Sequence & J1? & 2.1 & -10.1 \\
\hline STC 12A - Elongate Blocky (margin) & Sant Corneli Sequence & J1? & 2.4 & -10.6 \\
\hline STC 12A - Host 1 & Sant Corneli Sequence & J1? & 2.2 & -8.2 \\
\hline STC 12A - Host 2 & Sant Corneli Sequence & J1? & 2.1 & -7.9 \\
\hline STC 12A - Host 3 & Sant Corneli Sequence & J1? & 2.3 & -8.2 \\
\hline & & & & \\
\hline STC 12B - Blocky Calcite & Sant Corneli Sequence & J3? & 2.8 & -15.6 \\
\hline STC 12B - Host 1 & Sant Corneli Sequence & J3? & 1.6 & -8.0 \\
\hline STC 12B - Host 2 & Sant Corneli Sequence & J3? & 1.9 & -8.9 \\
\hline STC 12B - Host 3 & Sant Corneli Sequence & J3? & 2.3 & -9.1 \\
\hline & & & & \\
\hline STC 6 - Elongate Blocky Calcite & Aren Group & J2 & 0.8 & -7.7 \\
\hline STC 6 - Host 1 & Aren Group & J2 & 1.3 & -4.7 \\
\hline STC 6 - Host 2 & Aren Group & J2 & 1.1 & -4.2 \\
\hline STC 6 - Host 3 & Aren Group & J2 & 1.2 & -4.2 \\
\hline & & & & \\
\hline STC 13 - Large Blocky Calcite & Sant Corneli Sequence & J4 & 2.5 & -14.5 \\
\hline STC 13 - Small Blocky Calcite & Sant Corneli Sequence & J4 & 2.4 & -7.5 \\
\hline STC 13 - Hematite & Sant Corneli Sequence & J4 & 1.3 & -12.0 \\
\hline STC 13 - Goethite & Sant Corneli Sequence & J4 & 2.3 & -8.0 \\
\hline STC 13 - Host 1 & Sant Corneli Sequence & J4 & 3.0 & -6.9 \\
\hline STC 13 - Host 2 & Sant Corneli Sequence & J4 & 2.7 & -6.9 \\
\hline & & & & \\
\hline STC 1 - Blocky Calcite & Vallcarga Sequence & J5 & 3.2 & -2.8 \\
\hline STC 1 - Host 1 & Vallcarga Sequence & J5 & 3.0 & -2.4 \\
\hline STC 1 - Host 2 & Vallcarga Sequence & J5 & 3.1 & -2.4 \\
\hline STC 1 - Host 3 & Vallcarga Sequence & J5 & 2.9 & -2.3 \\
\hline
\end{tabular}

